
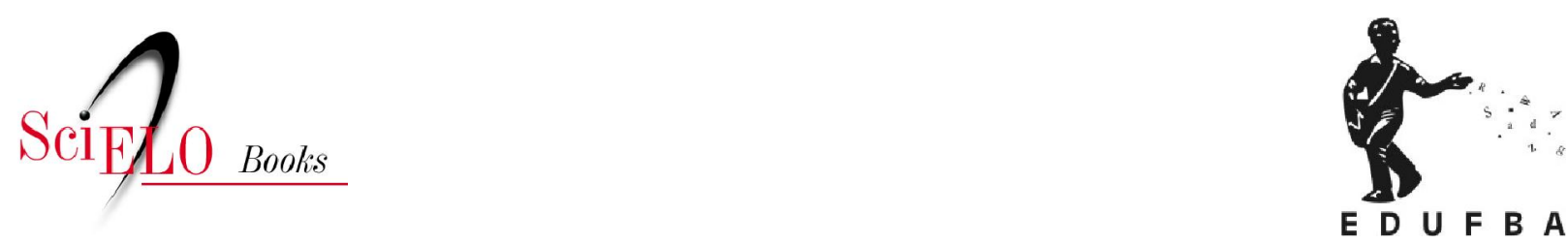

\title{
Confrontos e tréguas
}

\author{
Silvia Noronha Sarmento
}

SciELO Books / SciELO Livros / SciELO Libros

SARMENTO, S. N. Confrontos e tréguas. In: A raposa e a águia: J.J. Seabra e Rui Barbosa na política baiana da primeira república [online]. Salvador: EDUFBA, 2011, pp. 99-185. ISBN 978-85232-1153-0. Available from: doi: 10.7476/9788523211530.005. Also available in ePUB from: http://books.scielo.org/id/ykf8q/epub/sarmento-9788523211530.epub.

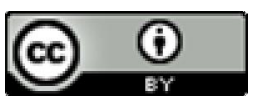

All the contents of this work, except where otherwise noted, is licensed under a Creative Commons Attribution 4.0 International license.

Todo o conteúdo deste trabalho, exceto quando houver ressalva, é publicado sob a licença Creative Commons Atribição 4.0.

Todo el contenido de esta obra, excepto donde se indique lo contrario, está bajo licencia de la licencia Creative Commons Reconocimento 4.0. 


\section{A \\ CONFRONTOS E TRÉGUAS}

\section{Embates preliminares (1902-1906)}

A primeira escaramuça pública entre o senador Rui Barbosa e o então deputado federal Seabra, líder do governo na Câmara, deu-se em 1902, por um motivo aparentemente trivial. Responsável pela condução do projeto do primeiro Código Civil republicano, em tramitação no Congresso, Seabra entregou o texto, elaborado pelo jurista Clóvis Bevilacqua, ao professor Ernesto Carneiro Ribeiro, para a revisão gramatical, antes que o projeto passasse pelo Senado, ou seja, antes que passasse pelas mãos do senador Rui Barbosa. Rui, que era a maior referência em estilo e retórica do país, não gostou. Dedicou-se, então, a apontar defeitos da revisão de Carneiro Ribeiro (que havia sido seu professor na Bahia). A querela gramatical, que deu origem à famosa Réplica de Rui, contribuiu para atrasar a aprovação do novo Código Civil e revelou, pela primeira vez, uma tensão entre o consagrado senador Rui e o ascendente deputado Seabra.

O deputado pernambucano Medeiros e Albuquerque comentou o episódio, atribuindo a reação de Rui (e os transtornos decorrentes) 
ao excesso de entusiasmo governista de Seabra, que se esforçava para terminar o Código Civil ainda no mandato de Campos Sales:

Todos sabem como a discussão e a elaboração desse trabalho foi feita na Câmara. Nomeada uma comissão de vinte e um membros, o Sr. Seabra se arvorou em seu presidente. Homem para gritar e esmurrar mesas, a título de estar fazendo alta eloqüência e declamação parlamentar, a sua incapacidade para qualquer trabalho de pensamento revelou-se desde logo $[\ldots]$

Depois, para ele, aquilo era uma empreitada como qualquer outra; discutir o Código Civil ou defender uma violência policial do Governo é exatamente, no seu espírito, a mesma coisa. Quando ele "pega num serviço" o que quer é dar conta dele, brutalmente, o mais depressa possível. Se é coisa de tribuna, o homem esbraveja, fica apoplético, esmurra valentemente a bancada - e sai radiante, com a tarefa concluída. Tinham-lhe dito que era preciso dar pronta uma discussão do Código. Ele ajustou o serviço e fez. Fez - do modo "brilhante" que todos viram. (BARBOSA, 1902, v. 29, t . 4, p. 129-130)

Quanto a Rui, apesar da erudição demonstrada na Réplica, sua responsabilidade pelo atraso do Código Civil foi retomada várias vezes pelos adversários como exemplo de vaidade intelectual colocada acima do interesse do país. No mesmo texto em que criticou Seabra, Medeiros e Albuquerque reservou o seguinte comentário para a atitude de Rui no episódio: "O Sr. Rui é da estirpe daquele rei de Castela, que lamentava não ter assistido à criação do mundo para dar uns bons conselhos ao Padre Eterno... E acreditem que, se isso tivesse sucedido, ainda se queixaria de que não lhe 'tivesse cabido a honra da primeira redação' do Universo..." (BARBOSA, 1902, v. 29, t. 4, p. 129, 131)

O ano de 1902, como já se registrou, marcou mudanças importantes, tanto na trajetória de Rui quanto na de Seabra. Para Rui, era o momento de deixar a trincheira da oposição permanente para se articular com o poder instituído, personificado no senador Pinheiro Machado. O gaúcho tinha habilidades políticas bastante complementares às suas.

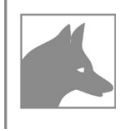


Era um mestre nas articulações de bastidores, nas negociações com os partidos estaduais, no controle do "reconhecimento" de mandatos alheios. Pinheiro era o nome nacional do Rio Grande do Sul, representante do grupo castilhista perpetuado pelo governador Borges de Medeiros, mas tinha ascendência também sobre os governadores do Norte (definição regional bastante imprecisa, que hoje incluiria também o Nordeste). Rui, que tinha dificuldades em estabelecer essas articulações internas do poder, era imbatível no espaço público, na tribuna e na imprensa. A aliança possibilitava ao baiano acalentar seu sonho de ser presidente do Brasil.

Para Seabra, a nomeação para o Ministério da Justiça e Negócios Interiores, também em 1902, representou uma grande guinada. Era uma pasta importante, pois englobava a administração da Justiça, inclusive eleitoral, saúde, educação, polícia, entre outras. No mandato de Rodrigues Alves, a responsabilidade era ainda maior, pois se pretendia levar a cabo a reforma da capital federal, "embelezando" o ambiente urbano, conforme as normas estéticas em voga na Europa, saneando e erradicando as doenças contagiosas que ali grassavam. Buscava-se, enfim, civilizar o Rio de Janeiro, principal vitrine do país, e a tarefa caberia, em parte, ao novo ministro.

Seabra foi uma figura destacada no ministério por vários motivos. Foi ele quem convidou o médico Osvaldo Cruz para dirigir a saúde. Tornou-se, mais tarde, um dos alvos da fúria popular, ao participar pessoalmente da repressão à revolta da Vacina e à simultânea revolta da Escola Militar. Mas, sua atuação ficou marcada também pelas realizações: além da reforma da capital federal, deu início a obras na Bahia (reforma da Faculdade de Medicina após incêndio, porto de Salvador) e Pernambuco, organizou a polícia civil no Rio de Janeiro, reformou serviços públicos. Cumpriu, enfim, de forma eficiente, as tarefas do cargo (inclusive as tensas negociações políticas da pasta), o que lhe rendeu o reconhecimento do presidente Rodrigues Alves. Como ministro interino de Negócios Exteriores, iniciou as negociações para incorporar o território do Acre. 
O ministério tinha sob sua responsabilidade grande quantidade de cargos, contratos e obras, além de proporcionar ampla visibilidade e prestígio. Era uma oportunidade para Seabra se firmar definitivamente na política baiana e nacional, e ele fez de tudo para aproveitá-la. Começou a formar um agrupamento próprio na Bahia, atraindo jovens doutores seduzidos por sua liderança carismática e pelas possibilidades de ascensão do ministério. Atento ao combate no campo do jornalismo, manteve veículos favoráveis a seu grupo, no Rio e em Salvador. Assim, por exemplo, se o Correio da Manhã (RJ), de abrangência nacional, massacrava o ministro da Justiça, lá estava O País (RJ), também muito influente, a defendê-lo. Em Salvador, os seabristas se expressaram, inicialmente, através do jornal Correio do Brasil, passando depois a O Norte.

A nomeação de Seabra para o ministério não foi submetida ao governador da Bahia, Severino Vieira, que tentou mesmo derrubá-la. Mantendo-o na pasta, o presidente tinha um ponto de tensão constante com o governo baiano, que temia a crescente interferência do ministro na política estadual. De fato, já em 1903, Seabra começou a divergir do partido dominante na Bahia, opondo discreta resistência à escolha de José Marcelino de Sousa como candidato ao governo. (SOUSA, 1949, p. 5) Indicado por Severino Vieira, José Marcelino representava a continuidade do seu mando e o fortalecimento do Partido Republicano da Bahia (PRB), primeiro partido relativamente organizado do estado. (SAMPAIO, 1998) Seabra era membro fundador do PRB, chefiado por Severino Vieira, mas, com a força do ministério, começava a fazer valer sua influência de forma autônoma.

Os descontentes com a indicação de José Marcelino aventaram outros nomes, inclusive o de Seabra, ainda com pouca repercussão, e o de Rui. A candidatura Rui teve grande aceitação, mas, diante de alegações de inelegibilidade, por não residir na Bahia há mais de dez anos, o senador declinou da oferta, declarando que não aceitaria a "honra do governo desse estado, senão no caso desse sacrifício ser imposto por afirmação 
geral da vontade da Bahia". (sousA, 1949, p. 7) Rui preferiu apoiar a candidatura de José Marcelino, que se tornaria seu mais importante aliado na política baiana. No governo Marcelino, de fato, o senador voltou a exercer plenamente sua influência na Bahia, nos moldes estabelecidos no início da República. Ele deixava as questões baianas serem resolvidas pelo governador e, em troca, era tratado como "plenipotenciário da Bahia junto ao governo federal”. (sousA, 1949, p. 5)

A relação dos governistas baianos com o governo federal, contudo, começou a se desgastar, a partir de 1905. O estopim foi a implantação da reforma eleitoral promovida pela Lei 1.269, que alterava a geografia dos distritos eleitorais, onde ocorriam as eleições proporcionais. $\mathrm{O}$ ministro Seabra, responsável pela reconfiguração dos distritos, pediu aos partidos de cada estado que dissessem como seus estados deveriam ser divididos, mas ignorou as sugestões do governador da Bahia, estabelecendo a divisão conforme seus próprios critérios (Figura 3). Era um passo claro no sentido de pavimentar o caminho para o controle político do estado natal. Os distritos criados por Seabra privilegiavam, como era de se esperar, as cidades onde ele era mais forte. $\mathrm{O}$ primeiro distrito seguia a linha ferroviária de Salvador a Alagoinhas. A sede do terceiro distrito, Bonfim, também estava situada na ferrovia. O imenso quarto distrito, que incluía todo o oeste, a região do São Francisco e as Lavras, passou a ser sediado pela pouco desenvolvida cidade de Barra do Rio Grande (Barra). A escolha de Cachoeira como sede do segundo distrito desprestigiava Nazaré, reduto do próprio José Marcelino. Diante disso, o governo da Bahia viu-se obrigado a romper relações com o governo federal, que continuava prestigiando seu ministro da Justiça. (sousA, 1949, p. 83-85) 
Figurs 3. Mapa esquemático de distritos eleitorais da Bahia (1893-1905)

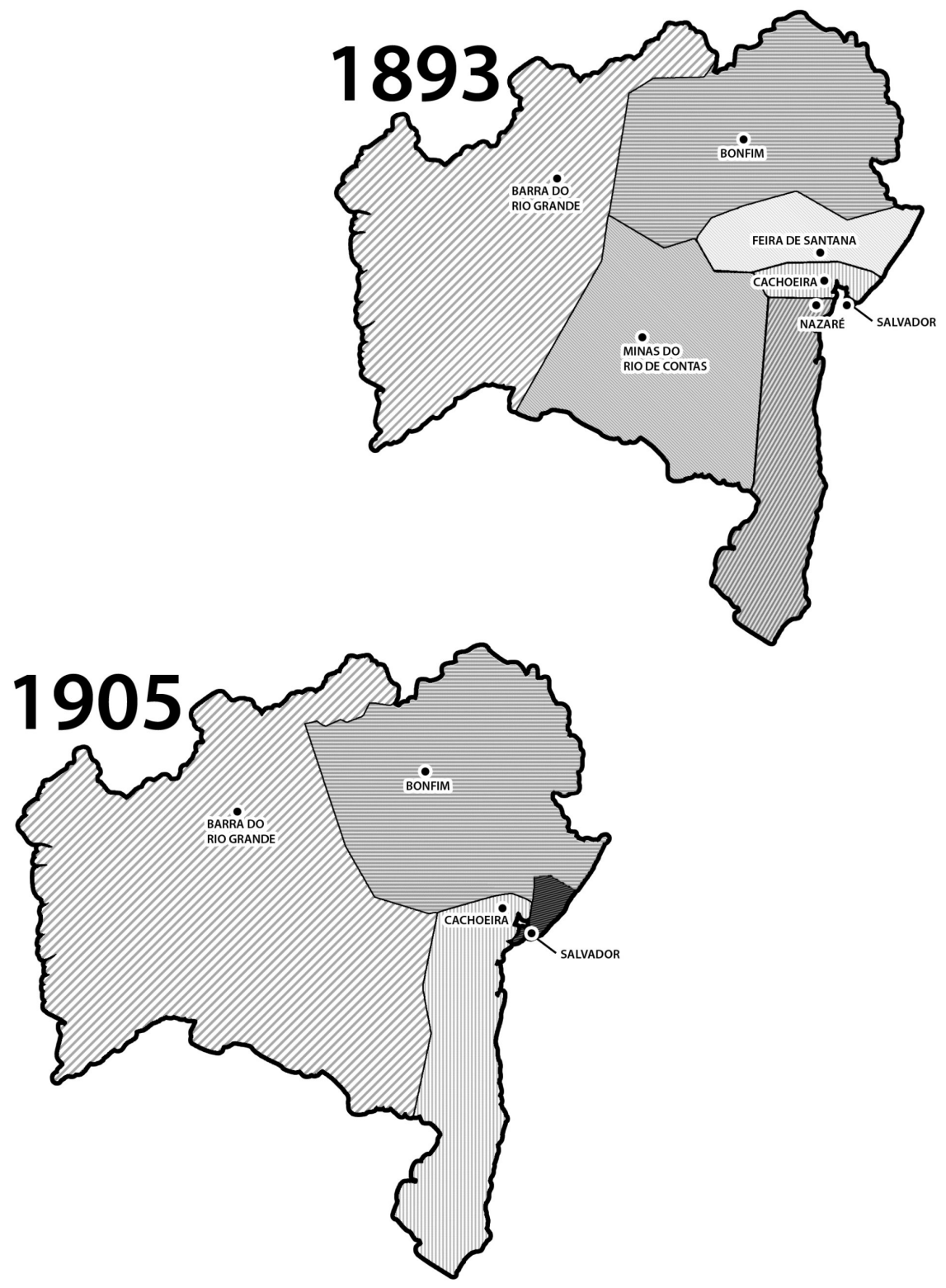

Fonte: Mapas elaborados a partir de: BRASIL. Decreto n. 153, de 3 de agosto de 1893 / Decreto n. 1425 de 27 de novembro de 1905.

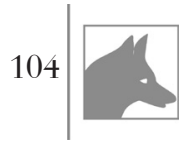


Em março de 1905, José Marcelino lançou a candidatura presidencial de Rui Barbosa à revelia do Catete, que tentava viabilizar o nome do ministro Bernardino de Campos como sucessor. Era um sinal de rebeldia dos baianos e também uma forma de participar das articulações sucessórias com um nome de relevância nacional. $\mathrm{O}$ acionamento do prestígio de Rui também servia como anteparo ao avanço seabrista, pois, como comentou Severino Vieira a José Marcelino: "o lançamento da candidatura do Rui teve o grande efeito político de afastar do Seabra, pelo menos por enquanto, a imprensa neutra da nossa terra". Rui não foi eleito, nem mesmo saiu candidato oficialmente, mas foi vitorioso nessas eleições. Seu grupo, o Bloco, que liderava ao lado de Pinheiro Machado, conseguiu impor uma derrota ao governo federal. $\mathrm{O}$ argumento era de que não cabia ao presidente escolher o sucessor. Eles defendiam a escolha de um nome pelos "próceres" estaduais, ou seja, alguém referendado pelo próprio Bloco. Nessas negociações, Rui atuou em nome da Bahia, com carta branca do governador. "Quem fala e resolve pela Bahia, neste assunto, já o tenho dito e repetido sem reservas, é, unicamente, V.", escreveu-lhe José Marcelino. O novo presidente, o mineiro Afonso Pena, foi eleito com forte apoio de Rui, que viu crescer sua influência no plano federal. (sousA, 1949, p. 87, 58)

Seabra, que havia se esforçado pela candidatura do Catete, ficou do lado perdedor. Sem o apoio do próximo presidente, hostilizado pelos governistas baianos, suas perspectivas eram sombrias ao deixar o ministério. Diante de sua fragilização, os chefes do PRB trataram de desfazer suas tramas na política baiana. José Marcelino trouxe a público uma carta de fevereiro de 1905, em que Seabra o instava a romper com Severino Vieira, reorganizando o PRB sob sua influência. Foi o pretexto para se excluir os seabristas da chapa oficial para as eleições seguintes. Os partidários de Seabra fundaram, então, um Partido Republicano Dissidente. Fizeram questão de incluir, em sua chapa eleitoral, o nome de Rui Barbosa, já presente na chapa oficial, alegando que seria "crime de 
lesa-patriotismo" excluir o ilustre senador. (O NORTE, 18 jan. 1906 apud SAMPAIO, 1998, p. 84) Parecia uma tentativa desesperada de obter o apoio de Rui no Congresso Nacional. A deferência de nada adiantou, pois nenhum dos seabristas foi considerado eleito.

O expurgo seabrista teve certa repercussão, pois contrariava a nova lei eleitoral, que previa uma cota para a representação das oposições estaduais. Rui precisou tratar do assunto publicamente. Em discurso no Senado (15 maio 1906), ele negou rumores de que o apoio baiano ao convênio de Taubaté, realizado naquele ano, tivesse sido negociado em troca da "degola” dos seabristas. Desqualificou o partido dissidente ("uma improvisação da véspera, constituída em torno da autoridade exclusiva de um ministro"), atribuindo seu fracasso nas urnas à estratégia definida pelo seu chefe (Seabra), que dispersou votos, em vez de concentrá-los. Insinuou, ainda, que os oposicionistas estariam envolvidos no atentado fracassado contra José Marcelino ${ }^{1}$, que, se bem sucedido, "teria mudado, transposto, invertido inteiramente a situação política da Bahia”. (BARBOSA, 1906, v. 33, t. 1, p. 11, 16)

Mas, o golpe maior na primeira tentativa de Seabra de se firmar na política estava por vir. Em setembro de 1906, foi eleito senador federal por Alagoas, com o apoio de Euclides Malta, chefe da família que monopolizava a política daquele estado. Não se sabe que vantagem os Malta tiveram para lhe ceder uma cadeira no Senado, mas as eleições ocorreram com a "regularidade" que só uma oligarquia bem assentada no poder, como a alagoana, poderia proporcionar. Euclides Malta arranjou 12.412 votos (6.322 "a descoberto", isto é, abertos, e 6.090 secretos) para Seabra, sem que o baiano precisasse pôr os pés em Alagoas. $\mathrm{O}$ candidato da oposição, Leite e Oiticica, recebeu oficialmente 410 votos, mas ganhou o apoio informal do governo baiano e do Bloco. A disputa maior anunciava-se para o Congresso Nacional, onde o candidato eleito deveria ter seu diploma reconhecido. (CASTRO, 1990; SANTOS, E., 1990)

1 Em 12 out. 1905, José Marcelino foi ferido por um homem chamado José da Circuncisão, preso em seguida. Durante a apuração policial, foram apontados indícios de envolvimento de políticos vianistas, que estavam na oposição.

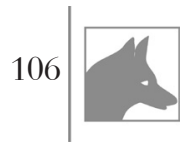


A eleição foi anulada no Congresso, dando origem a uma polêmica. Muitos atribuíam a "degola" à ação de Rui Barbosa e Pinheiro Machado. Em discurso no Senado (20 nov. 1906), Rui protestou contra a "campanha de ódios e mentiras" dos jornais sobre o assunto. Negou a existência de um antagonismo pessoal entre ele e Seabra, admitindo apenas um "antagonismo político, notório, manifesto [...] decorrente de circunstâncias que todos presenciaram, e que até hoje ninguém esqueceu". (BARBOSA, 1906, v. 33, t. 1, p. 172) Essas "circunstâncias" eram as recentes investidas de Seabra sobre a política baiana, assim referidas por ele:

Ninguém ignora a atitude assumida pelo ilustre candidato por Alagoas em relação ao meu Estado natal. Ninguém esqueceu ainda a carta endereçada por S. Ex. ao governador da Bahia, onde aquele ilustre brasileiro era convidado, a troco do aceno dos elementos federais manejados pelo ministro da Justiça, a romper com seus amigos, com a organização do seu partido e com as tradições e deveres em que ele se assentava, pra constituir uma política nova, depondo o chefe e organizando o Partido Republicano da Bahia segundo outras normas e outra direção. (BARBOSA, 1906, v. 33, t. 1, p. 173)

No mesmo discurso, Rui teceu um histórico de suas relações com Seabra, evidentemente a partir do seu ponto de vista. Recordou as boas relações do início da República, o habeas corpus que pediu a seu favor, o apoio prestado nas difíceis eleições de 1896, as relações amistosas que mantinham quando Seabra foi nomeado ministro e, visitando com frequência a casa de Rui, o abraçava e assegurava que ele seria o "conselheiro de todos os seus atos". (BARBOSA, 1906, v. 33, t. 1, p. 177) As divergências entre os dois, segundo Rui, teriam ocorrido em ocasiões isoladas, por discordância de opiniões, nunca por questões pessoais.

O problema, realmente, não parece ter sido pessoal, mas político. O crescimento de Seabra já significava, àquela altura, uma ameaça ao equilíbrio das relações entre Rui e os que dominavam o governo da Bahia. De deputado praticamente desconhecido, ele se tornara um 
ministro importante, firmando-se como um representante baiano alternativo no país. Por outro lado, a tentativa de articular seu próprio grupo na Bahia, algo que Rui nunca fez, ameaçava os grupos estabelecidos na política estadual. Tanto Rui como os políticos do PRB tinham motivos para hostilizá-lo. Ao comentar o assunto em seu diário pessoal, ainda em maio de 1906, o presidente Rodrigues Alves avaliava assim as perspectivas políticas de seu ex-ministro:

A idéia da entrada do Dr. Seabra para o Senado tem alarmado o mundo político, o bloco. Tem-se medo dele. Todos os esforços serão para arredá-lo do Senado e se diz abertamente que lá não entrará. A sua entrada é uma ofensa ao Rui, que resignará à sua cadeira se isso se der - é a linguagem misteriosa dos seus amigos. (1906, apud SANTOS, E., 1990, p. 37, grifo no original)

Para Seabra, esse primeiro confronto direto com Rui terminou em derrota. Na nova eleição que se realizou em Alagoas, após a anulação da primeira, o baiano sequer foi candidato. Euclides Malta já se julgava desobrigado do compromisso e preferiu eleger seu próprio irmão, que foi reconhecido sem problemas, apesar da eleição ter sido realizada com os mesmos métodos da anterior. Sem mandato, Seabra não teve remédio senão fazer barulho. Viajou a Maceió para agradecer os votos recebidos, fez conferências em Salvador e em Recife, e publicou oito artigos contra Rui na imprensa do Rio de Janeiro, entre março e abril de 1907. Nesses artigos, protestou contra o "esbulho" do seu mandato, que considerou "uma afronta contra a soberania do Estado de Alagoas". Traçou uma breve autobiografia, louvando a própria origem "pobre" e dizendo não ser "saltimbanco político", nem "intrigante de bastidores" - essas eram, provavelmente, críticas comuns ao seu estilo de fazer política. Deu sua versão do histórico de suas relações com Rui, confirmando a cordialidade do início, mas acrescentando alguns episódios negativos à imagem do conterrâneo. Foram esses os artigos citados no segundo capítulo, aos quais Rui respondeu com o discurso no Senado, antes de embarcar para Haia. (CASTRO, 1990) 
Em resposta, Rui declarou que o resultado da segunda eleição alagoana era uma prova de que o Senado agiu corretamente ao anular o primeiro pleito. Afinal, argumentou, se os milhares de votos dados a Seabra fossem, de fato, a "expressão da vontade popular", eles deveriam aparecer novamente na segunda eleição, o que não ocorreu. $\mathrm{O}$ argumento baseava-se no esquecimento deliberado do modo como se processavam as eleições no país. Rui sabia que o resultado das eleições em Alagoas dependia do interesse dos Malta, não da vontade popular, e que a segunda votação fora tão corrupta quanto a primeira. Mas, fingia acreditar no resultado das urnas para justificar a controversa "degola" do rival. Rui ainda ironizou os rumores de que mandara anular a eleição alagoana por "medo" de enfrentar Seabra no Senado, "porque, de certo, não podia resistir aos seus embates, ou porque a sua própria presença seria para mim, nesse recinto, uma cabeça de Medusa”. (BARBOSA, 1907, v. 34, t. 1, p. 28-30)

Frustrou-se, assim, completamente a primeira tentativa de Seabra de se estabelecer como chefe na Bahia e como líder baiano no país. O ex-ministro entrou em um período de ostracismo político. Não tardaria, porém, para que as instabilidades da política baiana (cisão do PRB) e os projetos do próprio Rui (campanha presidencial de 1910) possibilitassem seu retorno, em vertiginosa curva ascendente, que culminaria no controle do governo da Bahia em 1912. Aí, verdadeiramente, a raposa e a águia teriam um combate digno de suas forças.

\section{A campanha civilista (1909-1910)}

Em 06 de fevereiro de 1909, José Joaquim Seabra figurava entre os que se despediam do ex-governador José Marcelino, chefe do Partido Republicano da Bahia, na ponte da Navegação Baiana. Era mais uma cerimônia de embarque, daquelas tão frequentes em Salvador, mas, dessa vez, não havia banda de música, nem foguetório, pois o homenageado não se 
dirigia à Europa, nem mesmo ao Rio de Janeiro. Apenas atravessaria a baía de Todos os Santos, em direção à cidade de Nazaré, onde estava sua propriedade agrícola, o engenho Xangó. Não obstante, lá estava o ex-ministro Seabra na despedida. Foi citado sem destaque pelo jornal A Babia (07 fev. 1909), em meio a funcionários públicos e políticos de diversos escalões, que aproveitavam para demonstrar publicamente sua lealdade ao chefe que partia.

A presença de Seabra nesse evento de pequena expressão pode ser tomada como um indício da fragilidade com que ele, então, retornava à política baiana. Após a "degola" do Senado, Seabra entrou em uma espécie peculiar de ostracismo: não ocupava cargo público, mas seus partidários baianos continuavam se referindo a ele como chefe e se comportavam como um grupo à parte no Senado e na Câmara Estadual. Em 1907, enquanto os jornais publicavam seus artigos contra Rui, ele viajou à Europa em companhia do tio, Manuel Alves Barbosa, que buscava tratamento de saúde, mas acabou falecendo. Ao regressar com o corpo, meses depois, Seabra já estava informado de que o tabuleiro baiano havia sofrido importantes alterações.

Em abril de 1907, o governador José Marcelino rompeu com o antecessor, Severino Vieira, no que ficou conhecido como a "cisão" do PRB. Dois grupos distintos passaram a disputar o controle do governo estadual. De um lado, Severino estava fortalecido, após seis anos como chefe do partido, com maioria nas duas casas legislativas estaduais e na bancada da Câmara Federal. José Marcelino, por sua vez, era o governador, isto é, dispunha da máquina governamental, da justiça e da polícia para influir nas eleições. Além disso, tinha aliados na esfera federal, dos quais o principal era o senador Rui Barbosa. Rui se envolveu tanto nessa disputa baiana que cogitou até em desistir de participar da conferência de Haia para ficar no Brasil, apoiando José Marcelino. (SAMPAIO, 1998, p. 94-97)

É interessante lembrar que, menos de um ano antes, Rui havia criticado Seabra por instigar o governador a romper com "seus amigos, 
com a organização do seu partido e com as tradições e deveres em que ele se assentava”. (BARBOSA, 1906, v. 33, t. 1, p. 173) Agora, o próprio Rui se envolvia na disputa, ao lado daquele que se tornara seu aliado mais confiável. De fato, Severino Vieira sempre manteve uma postura hostil a Rui, tolerando sua ascendência sobre a política baiana com relutância. Ele havia sido ministro de Campos Sales e tinha maior trânsito nacional do que José Marcelino, que era um nome restrito à Bahia. Na "queda-de-braço" entre Severino e Marcelino, a força nacional de Rui foi fundamental para ajudar o governador a superar a força estadual do antigo chefe. Foi, provavelmente, graças a ele que os marcelinistas obtiveram o decisivo apoio do presidente Afonso Pena às suas pretensões.

A cisão do PRB possibilitou aos seabristas uma nova inserção na política dominante da Bahia, dentro do grupo vencedor. Eles ajudaram a pesar a balança para o lado marcelinista, que conseguiu empossar o novo governador, João Ferreira de Araújo Pinho, em maio de 1908. Em troca, Seabra encerrou seu próprio ostracismo político, com um mandato de deputado federal. Candidato do primeiro distrito, fez campanha eleitoral de trem até Alagoinhas, sendo saudado em cada parada pelos chefes locais. Pedia votos, não só para si, mas para toda a chapa oficial, afirmando sua lealdade aos marcelinistas, dos quais dependia sua eleição. $\mathrm{O}$ resultado the foi favorável. Com 7.628 votos, foi o segundo candidato mais votado do distrito, atrás apenas de Antônio Calmon. Como deputado eleito, mas não reconhecido, Seabra ainda precisava das boas graças do governo estadual. No almoço de despedida, antes de partir para o Rio de Janeiro, atribuiu a eleição à "aprovação, por parte do povo, dos seus atos como parlamentar e ministro, e da sua atitude de franco apoio à atual situação baiana”. Concluiu brindando a Bahia, "cuja apologia fez na pessoa do seu digno governador, que a representa com altivez, dignidade, dedicação, honra e patriotismo". (GAZETA DO POVO, 08 jan. 1909, 15 fev. 1909)

Dois dias depois, na chegada festiva à capital federal, Seabra já proclamou um discurso que deu margem a dúvidas sobre sua lealdade aos 
governistas baianos. Não foi possível encontrar suas palavras exatas nas fontes consultadas, mas os desmentidos publicados na seabrista Gazeta do Povo informam que ele proferiu um ataque às oligarquias estaduais, prometendo combatê-las no Congresso Nacional. O discurso foi interpretado, especialmente pelos severinistas, como uma ofensiva ao grupo dominante na Bahia. Diante disso, o correspondente da Gazeta do Povo mandou a seguinte nota de esclarecimento:

Em resposta às explorações de certos jornais, o Dr. Seabra mantém a sua opinião sobre oligarquias, e pergunta-nos onde está a oligarquia da Bahia, onde nenhum dos seus governadores tem parentesco próximo ou afastado.

Nada têm, portanto, suas palavras que ver com a política baiana, com a qual é inteiramente solidário. (GAZETA DO POVO, 22 fev. 1909)

Aproveitando-se da polissemia do termo, Seabra adotou o conceito de oligarquia que lhe convinha no momento, que era o que restringia as oligarquias aos governos familiares. Com essa ressalva, podia manter "sua opinião sobre oligarquias", ou seja, podia se inscrever entre os que denunciavam os arranjos oligárquicos como um dos males da República, sem, necessariamente, romper com o governo baiano. Era sempre muito desagradável estar na oposição.

O combate às "oligarquias" era, então, o principal tema político do Brasil. A emergência dessa questão, como já se comentou, trazia à tona a insatisfação com as promessas não cumpridas pela República e a aspiração por modelos centralizadores. Na eleição presidencial de 1910, essa aspiração encontrou uma brecha para se manifestar na incapacidade dos chefes estaduais em obter um consenso. $\mathrm{O}$ candidato preferido do presidente Afonso Pena, o ministro Davi Campista (escolha referendada pelos cafeicultores paulistas) não foi aceito por Rui e Pinheiro Machado, que alegavam que o Catete não deveria indicar o sucessor. Rui lembrou 
a Afonso Pena de que esse princípio havia sustentado sua própria candidatura, em 1906, contra o candidato preferido de Rodrigues Alves. (BARBOSA, 1909, v. 36, t. 2; VISCARDI, 2001, p. 176-177)

Apesar da argumentação baseada em princípios, e das negativas de que fosse candidato, era óbvio que Rui protestava em causa própria. $\mathrm{O}$ senador baiano era um dos nomes mais citados nos jornais como aspirante ao Catete e o momento lhe parecia muito favorável. Aos 60 anos, ele desfrutava de imensa popularidade, consagrado como grande herói intelectual do Brasil. Para isso, muito contribuiu sua brilhante participação na Conferência de Haia, em 1907. Em 1908, Rui foi eleito presidente da Academia Brasileira de Letras. Era vice-presidente do Senado, mais alto cargo da casa, e amigo de Afonso Pena, seu colega de faculdade. Desde a posse de Rodrigues Alves, vinha mostrando não ser apenas um ferrenho opositor, mas alguém capaz de articular o jogo político nacional, ao lado do aliado Pinheiro Machado. Em 1905, Rui retirara sua própria candidatura, lançada pela Bahia, em favor de Afonso Pena. Nada mais natural do que esperar uma retribuição do presidente. (GONÇALVES, 2000b, p. 115-122)

Afonso Pena, porém, insistiu na candidatura Campista, que não encontrou apoio maciço sequer em Minas Gerais, terra natal do candidato e do presidente. Outros estados também opuseram resistência. Diante das dificuldades, vários nomes foram cogitados. Além de Rui, dois outros aspirantes ao Catete eram vistos como que pairando acima dos vícios da política "oligárquica": o barão do Rio Branco, ministro do Exterior, e o marechal Hermes da Fonseca, ministro da Guerra. Dois políticos de perfil tradicional, os ex-presidentes Rodrigues Alves e Campos Sales, ambos paulistas, eram também sempre lembrados.

$\mathrm{Na}$ Bahia, a crise sucessória teve efeitos importantes. Interessado em manter as boas relações com o governo federal, José Marcelino havia prometido ao presidente que a Bahia apoiaria a candidatura Campista. Há indícios, inclusive, de que esse apoio teria sido negociado em troca 
de futuros investimentos federais na rede ferroviária baiana. Com a oposição de Rui, José Marcelino teve que recuar a uma posição indefinida. Em janeiro de 1909, dois jornais baianos (Diário de Notícias e Gazeta do Povo) noticiaram uma suposta carta de Rui a Araújo Pinho, pedindo que a Bahia assumisse "atitude idêntica à que teve em 1905, não aceitando as imposições do Catete”. Em 1905, a Bahia manifestou independência lançando Rui à presidência. A carta seria um recado para o governador repetir o gesto do anterior. A resposta de Araújo Pinho, conforme essa versão, foi de que não poderia "contrariar Dr. Afonso Pena, que foi o verdadeiro criador da atual situação baiana". Tanto a carta como a resposta foram desmentidas pelos envolvidos. Rui negou os boatos, declarando, inclusive, que "nunca interveio nas deliberações da política baiana, senão quando chamado". (A BAHIA, 0608 jan. 1909)

O conteúdo das cartas pode ter sido inventado, mas a pressão de Rui sobre o governo baiano era real. Em abril de 1909, ele escreveu a Araújo Pinho dizendo que, desde janeiro, esperava uma resposta sobre a sucessão. Segundo Rui, pessoas de sua confiança lhe disseram que a Bahia havia assumido o compromisso de apoiar qualquer candidatura lançada pelo Catete. Ora, os chefes do PRB sabiam da posição de Rui a respeito. Logo, se resolviam agir de forma contrária às suas orientações, Rui concluiu que eles haviam deliberado sua "desligação da política da Bahia”, mas que o faziam "pelas costas", enquanto continuavam a tratá-lo como "amigo, conselheiro e chefe". Era evidente, para quem conhecia a retórica peculiar de Rui, que ele estava irritado:

Não quero negar à política baiana o direito de esposar qualquer candidatura presidencial, com o mesmo arbítrio que, há três anos, levantou a minha. Mas o que peremptoriamente lhe nego é a faculdade, que lhe seria injuriosa, de se associar a uma candidatura da iniciativa pessoal do presidente. (BARBOSA, 1909, v. 36, t. 2, p. 158) 
Bem se vê o tamanho da responsabilidade às costas dos marcelinistas. Optar pelo candidato do Catete significaria romper com Rui Barbosa, com as consequências de sempre, ampliadas pela popularidade de que ele desfrutava no momento. Por outro lado, adotar sua candidatura sem ter certeza de suas bases políticas era arriscar ficar na oposição ao futuro presidente, caso ele não fosse vitorioso. Por isso, José Marcelino e Araújo Pinho permaneciam indefinidos.

Os seabristas também se movimentavam com cautela. A Revista do Brasil, publicação baiana ligada a Seabra, publicou caricaturas em que ele aparecia apoiando o ex-presidente Rodrigues Alves, mas ele mantinha uma posição pública indefinida. Seu discurso contra as oligarquias é um indício de que ele poderia já estar associado aos partidários do marechal Hermes da Fonseca. Originada no seio do Exército, essa candidatura parecia encarnar, mais do que qualquer outra, o desejo de limpar a política oligárquica, através da mão forte de um militar desvinculado de qualquer grupo regional. Se Seabra já estava ligado aos hermistas, no entanto, demorou em assumi-lo. Chegou a negar ter estimulado a criação da Liga Politica Hermes da Fonseca na Bahia. (GAZETA DO POVO, 11 mar. 1909) Mantinha, assim, aberta a possibilidade de aderir à candidatura que mostrasse maior força, ao fim das negociações.

Paradoxalmente, foi o mesmo marechal Hermes - valente destruidor de oligarquias, no discurso de seus propugnadores - que obteve o apoio do maior número de chefes representantes das mais consolidadas oligarquias do país. Para isso, foi fundamental a adesão de Pinheiro Machado. Como em 1906, o gaúcho conseguiu esvaziar as pretensões do Catete, impondo-lhe um nome acertado pelos grupos dominantes nos estados mais poderosos, especialmente Rio Grande do Sul e Minas Gerais, que forneceu o candidato à vice-presidência. Mais uma vez, esses estados se uniam para combater a supremacia paulista, visível nos três primeiros governos civis. Desta vez, porém, o acordo não incluía o senador Rui Barbosa. O nome de Rui chegou a ser citado em uma 
reunião convocada por Pinheiro para definir o candidato do Bloco. Com a votação empatada entre Rui e Hermes, o gaúcho delegou o "voto de minerva" ao chefe pernambucano Francisco Rosa e Silva, que sabia ser desafeto do baiano. Após votar no marechal, selando a escolha do Bloco, Rosa e Silva ainda comentou, com ironia: "Com Rui, nem para o céu!"

Não era da personalidade de Rui Barbosa aceitar essa exclusão apaticamente. Três dias antes do lançamento da candidatura Hermes, veio a público uma carta sua combatendo-a frontalmente. Rui alegava que, como o marechal não tinha passado político, sua candidatura refletia apenas sua condição de militar. Tratava-se, então, segundo ele, de um retrocesso do sistema político brasileiro, que há tempos deixara os governos militares da transição republicana (Deodoro e Floriano) em direção a governos civis. Esse importante documento, conhecido como a "carta de bronze", porque correligionários de Rui quiseram perenizá-lo nesse material, instituiu um novo mote para a disputa eleitoral. A partir daí, em reação ao militarismo, supostamente encarnado por Hermes da Fonseca, emergiria o civilismo, que teria como candidato, a partir de 22 de agosto de 1909, o próprio Rui Barbosa.

Pela primeira vez na República, duas candidaturas presidenciais apresentavam-se ao confronto com certo peso político. Do lado hermista, alinhavam-se os grupos dominantes de Minas Gerais, Rio Grande do Sul e de todos os demais estados - exceto São Paulo, Bahia e, até certa altura, Rio de Janeiro - além de setores do Exército. Do lado oposto, que se chamaria civilista, os partidos governistas de São Paulo e Bahia, além das oposições de diversos estados. Em Minas Gerais, oficialmente hermista, desavenças internas puseram grupos relevantes do lado civilista. Havia, ainda, uma expectativa de apoio do Catete, inclinado a se compor com Rui e os paulistas, após o fracasso da candidatura Davi Campista. A morte de Afonso Pena (14 jun. 1909) extinguiu essa possibilidade. ${ }^{2}$

2 No Senado, Rui atribuiu o falecimento súbito de Afonso Pena a um "traumatismo moral" provocado pela candidatura de Hermes, seu ex-ministro da Guerra. Segundo o senador baiano, os médicos que atenderam o presidente lhe garantiram que todos os seus órgãos estavam "ilesos" - isso colocaria Hermes como responsável pela morte de Pena. Os hermistas rejeitaram a afirmação e chegaram a acusar Rui de conspirar contra a vida de 
O novo presidente, Nilo Peçanha, mostrou-se favorável ao hermismo, embora prometesse neutralidade. Quando a convenção civilista escolheu Rui Barbosa como candidato, suas chances de vitória já eram relativamente pequenas.

As mudanças no panorama definiram a questão para os governistas baianos. José Marcelino e Araújo Pinho tornaram-se pilares da candidatura Rui. Seabra aderiu ao hermismo, embora sem romper, no primeiro momento, com os marcelinistas. Continuava jurando lealdade ao governo baiano, pedindo licença apenas para divergir na questão presidencial. Equilibrou-se nessa fina linha, tentando atrair para seu lado o governador Araújo Pinho, até agosto de 1909, quando oficializou o rompimento. Os severinistas também aderiram ao hermismo com entusiasmo. Era esperado que Severino Vieira agarrasse a oportunidade de apoiar essa candidatura, que tinha grandes probabilidades de vitória e era inacessível aos adversários marcelinistas. A Bahia passou então a ser palco de uma disputa entre severinistas e seabristas para saber quem carregava mais alto a bandeira do hermismo no estado. Apesar de lutarem por um candidato nacional comum, contra um inimigo local comum, os dois grupos nunca se uniram.

A chamada "campanha civilista" é um dos períodos mais festejados da trajetória política de Rui. De forma nunca vista nas eleições presidenciais até então, o candidato baiano saiu em excursão eleitoral, proferindo conferências em três estados (São Paulo, Bahia e Minas Gerais), além do Distrito Federal. Eram viagens exaustivas, especialmente para o sexagenário Rui, que nunca teve uma saúde muito boa. Ele compensava, no entanto, com uma força de vontade surpreendente, que permitiu que ele cumprisse uma verdadeira maratona cívica. No trajeto de trem do Rio de Janeiro a São Paulo, por exemplo, ele parou para receber homenagens em seis cidades, no decurso de um só dia (14 dez.1909). Dias depois, na estação de Campinas, pediu desculpas por não poder discur-

Nilo Peçanha, já que, como vice-presidente do Senado, o baiano seria o sucessor legal em caso de morte do novo presidente. (GAZETA DO POVO, 17 jun. 1909) Essas graves acusações mútuas mostram como os ânimos estavam exaltados nessa campanha presidencial. 
sar muito, pois precisava poupar a voz, "como um tenor em véspera de estréia”. (BARBOSA, 1909, v. 36, t. 1, p. 233) Estava claro que o esforço da campanha era grande, mas, em contrapartida, a presença de Rui nessas cidades, repercutida pelos jornais civilistas, levou a uma mobilização também inédita em campanhas eleitorais no país.

Sua chegada à Bahia (14 jan. 1910) foi considerada uma "apoteose" pelos civilistas da terra. Era a primeira vez que um baiano era candidato à presidência da República, e não se tratava de um baiano comum: era Rui Barbosa, a Águia de Haia, herói da inteligência e da cultura nacional. Para as elites baianas, frustradas com a decadência política e econômica do estado, o sucesso de Rui era uma forte injeção de autoestima. Mas, a celebração da visita do filho ilustre não foi restrita apenas aos grupos mais privilegiados. Como já se comentou, alguns rituais políticos envolviam a maior parte da população da cidade. Isso foi especialmente verdadeiro no dia da chegada de Rui. O comércio fechou as portas, o expediente nas repartições públicas foi suspenso. As ruas por onde ele deveria passar foram enfeitadas e dotadas de iluminação especial. Tudo isso provocava um impacto no cotidiano da população, que viveu um dia de festa. (A BAHIA, 15 jan. 1909)

O navio trazendo o candidato chegou à enseada por volta das $14 \mathrm{~h}$, mas, entre evoluções navais, discursos, brindes e apresentações musicais a bordo, Rui demorou quase cinco horas para descer à Navegação Baiana. Estava, evidentemente, cansado, mas ainda teria que enfrentar o préstito que se formou para acompanhá-lo ao palacete das Mercês onde ficaria hospedado. Rui preferiu fazer o trajeto de carro, um landau disponibilizado pelo governador. Mesmo assim, o cortejo seguia lentamente, com interrupções periódicas para discursos, pois sempre havia um aspirante a Rui Barbosa ansioso por mostrar seu talento oratório a partir de alguma janela. Na Ladeira da Montanha, um grupo mais animado quis tomar o lugar da parelha de cavalos que puxavam o carro, só desistindo diante dos apelos do próprio Rui. Ao chegar ao destino, o homenageado estava exausto demais para discursar e pediu que o deputado Lemos Brito agradecesse, em seu nome, à multidão. (A BAHIA, 15 jan. 1910)

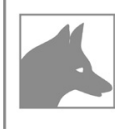


Como de praxe, após a parte aberta da cerimônia, seguiu-se um ritual exclusivo, um jantar no palacete das Mercês. O governador Araújo Pinho não economizou elogios ao homenageado, chegando a considerá-lo sobre-humano ao dizer que "o conselheiro Rui Barbosa, destacando-se das condições normais da espécie humana, subiu tanto, tão alto, que é o ponto de convergência das vistas admiradas de todos os povos do mundo”. (A BAHIA, 16 jan.1910) Rui, já recuperado do esforço diurno, agradeceu com um discurso e um brinde.

O candidato civilista passou seis dias em Salvador. Visitou a Associação Comercial, o Banco da Bahia, o Conselho Municipal, a Faculdade de Medicina e a Escola Comercial. O ponto alto da programação foi a conferência realizada no Politeama Baiano, no dia 15 de janeiro, na qual o candidato proferiu sua plataforma eleitoral, ansiosamente aguardada. Na convenção civilista (22 ago. 1909), a inexistência da plataforma servira de pretexto para a debandada do grupo gaúcho de Assis Brasil. Desde então, Rui vinha sendo pressionado para apresentar esse documento. $\mathrm{Na}$ véspera da conferência, os marcelinistas destacaram a honra que Rui fazia à Bahia ao proclamar em Salvador sua plataforma, tratada com o respeito de uma "revelação" sagrada:

Debalde lhe solicitaram essa incomparável distinção e honraria o cultíssimo povo da capital da República e as populações libérrimas do grandioso Estado de São Paulo, em cujos lábios seu nome laureado anda como o do salvador da Pátria, como o Messias do governo civil, neste momento soleníssimo em que o tigre do militarismo [...] à semelhança da fera do Apocalipse, afia, distende e ensaia as garras aduncas [...], para estraçalhar-nos as energias morais e as liberdades civis nobremente conquistadas, entregando-nos [...] à sanha incorporadora das grandes potências mundiais, das nações imperialistas do mundo contemporâneo [...].

A Bahia deveria ser o Sinai do Moisés brasileiro. Do alto desta montanha gloriosa deveriam descer, com as tábuas da Lei, os mandamentos sagrados da democracia que saneia, purifica e regenera. (A BAHIA, 14 jan. 1909) 
Referências religiosas misturavam-se a imagens patrióticas para reforçar a imagem de Rui como salvador da Pátria, sem o sentido pejorativo que a expressão tomaria mais tarde. A leitura da plataforma ocorreu em uma cerimônia que seguia as regras sociais da época. $\mathrm{O}$ "camarote nobre" foi reservado à família do governador e à esposa de Rui. As "famílias" eram conduzidas aos camarotes de primeira e segunda classe por membros do PRB, que os recebiam na porta do Politeama. A "grande massa de povo", que aguardava do lado de fora, entrou de forma menos elegante, aos empurrões e cotoveladas, assim que os portões se abriram. O público já estava acomodado quando uma comissão de políticos, precedida por uma banda de música, saiu em direção ao palacete das Mercês para buscar a estrela da noite. Rui entrou no recinto sob uma chuva de rosas, ao som do hino nacional. (A BAHIA, 16 jan. 1910)

A plataforma era um documento extenso e complexo que, se não trazia uma descrição clara de suas propostas de governo, explicitava aspectos relevantes do seu pensamento político. (BARBOSA, 1910, v. 37, t. 1, p. 11-108) Para a Bahia, no momento, o ponto de maior interesse referia-se às oligarquias e ao intervencionismo federal. Defensor da autonomia estadual, Rui minimizava o problema das oligarquias, considerando-as uma consequência indesejada, espécie de efeito colateral da "semissoberania" adquirida pelas províncias com o modelo federativo. "A corrupção das melhores coisas as degenera nas piores”, comentou. Ele praticamente limitava o problema das oligarquias aos estados do Norte (definição que, no caso, excluía a Bahia) e sugeria uma solução política, sem recurso às armas, para acabar com elas. $\mathrm{O}$ governo federal deveria, simplesmente, parar de fornecer os benefícios que as sustentavam no poder: "não intervenham, mas não favoreçam, não invadam a esfera dos governos estaduais, mas também não os cubram da sua boa sombra. Cesse, em suma, a União de ser o guarda-costas das oligarquias locais e estas, dentro em breve, expirarão naturalmente, asfixiadas na sua impopularidade”. (BARBOSA, 1910, 37, t. 1, p. 43-45) 
Teoricamente, Rui estava certo. Era realmente a conivência do governo federal que sustentava os grupos estaduais no poder. Mas, a recíproca também era verdadeira, pois o poder central teria dificuldades em se manter estável caso contrariasse a força dos grupos que dominavam os estados mais poderosos. E quem poderia dizer quais arranjos estaduais eram legítimos, e quais não eram, se todo o sistema eleitoral era viciado? Não era fácil solucionar esse problema.

Os protestos contra o intervencionismo federal, de um lado, e as denúncias das oligarquias, de outro, revelavam, no fundo, uma persistente tensão entre centralização e descentralização. Os problemas apontados de parte a parte eram similares: abuso de poder, apropriação de recursos públicos, manipulação das eleições, clientelismo, fisiologismo, exclusão da maioria da população, entre outros. Eram males históricos, inerentes à própria constituição política do país, tanto no âmbito federal como no estadual e local. A questão estava no ponto de vista. Para os defensores da centralização (no caso, os hermistas), o problema maior estava nos desmandos das oligarquias, enquanto os partidários da descentralização (os civilistas) temiam o autoritarismo do poder central e a perda de autonomia das unidades federadas.

É bem verdade que essas tomadas de posição não eram radicais. Algumas vezes, eram ditadas pelas circunstâncias e aparentemente contraditórias. A família Acioli, que dominava o governo do Ceará, por exemplo, não tinha qualquer interesse em uma centralização que tirasse poder das oligarquias. No entanto, viu-se obrigada a apoiar o candidato hermista, que lhe parecia mais forte, para não correr o risco de ficar na oposição ao próximo governo federal. Da mesma forma, os castilhistas gaúchos que sustentavam a candidatura Hermes não queriam uma centralização que os impedisse de manter, em seu estado, um sistema político diferente do nacional. Por isso, fizeram questão de inserir no programa do marechal a manutenção integral da Constituição de 1891, com seu federalismo flexível, aberto às mais variadas interpretações. 
O polêmico artigo $6^{\circ}$ da Constituição de 1891, por exemplo, visava proibir a intervenção federal nos estados, mas abria exceções para "manter a ordem e a tranquilidade" e "cumprir leis e sentenças judiciais", entre outras, que o tornavam fácil de burlar. Em sua plataforma civilista, Rui denunciou que, para legalizar uma intervenção, bastava que o governo federal arranjasse uma decisão judicial a seu favor, o que não era difícil, diante da dependência do Judiciário. Por isso, apesar de considerar necessária a intervenção em certos casos, o senador baiano pedia maior clareza da lei a respeito. Esse era um dos aspectos da revisão constitucional que Rui defendia, embora ele enfatizasse que sua maior preocupação, no momento, não era com a reforma da Constituição de 1891 (seus aliados paulistas não eram favoráveis a mudanças, já que o texto original os beneficiava em vários aspectos), mas sim com a defesa da ordem civil, diante do que ele considerava uma ameaça militar.

O caráter eminentemente militar da candidatura Hermes é, hoje, discutível. Autores como Bóris Fausto (1995) e José Murilo de Carvalho (2005) destacaram que a viabilização do seu nome dependeu principalmente da ação de elementos civis, dos chefes estaduais tradicionais liderados por Pinheiro Machado. Nada haveria de mais fundamentalmente oligárquico do que isso. Sem discordar de que esse foi o fator principal na viabilização da candidatura, Cláudia Viscardi (2001, p. 195) observa, no entanto, que havia um componente militar na origem da escolha do ministro da Guerra. Isso não quer dizer que todo o Exército estivesse engajado na campanha, nem que essa candidatura fosse exclusivamente militar. Dentre os partidários de Hermes, havia um subconjunto de militares, que viria a entrar em conflito com a parte civil do hermismo quando da execução das futuras salvações nacionais. Um bom exemplo é o caso de Pernambuco, onde, em 1911, um hermista militar (general Dantas Barreto) viria a destronar um hermista civil (Rosa e Silva), em nome da derrubada das oligarquias.

O perfil de Rui Barbosa e de Hermes da Fonseca, o relativo equilíbrio das forças, o recurso a novos temas, a promoção de uma campanha 
eleitoral diferente - tudo isso fez com que a eleição de 1910 proporcionasse uma mobilização política fora do comum, inclusive na Bahia. Não só o civilismo, mas também o hermismo agitou as ruas de Salvador com seus rituais políticos, como uma passeata realizada pelos severinistas (24 jul. 1909). No dia da chegada de Rui (14 jan. 1910), cada passo do cortejo civilista era acompanhado por gritos dos partidários de Severino e de Seabra, aclamando seus respectivos chefes e o marechal Hermes, candidato de ambos. Segundo A Babia, um dos grupos era liderado por um sobrinho do general Siqueira de Meneses, inspetor da 7a Região Militar, sediada na Bahia. O próprio Rui lamentou a presença de hermistas do lado de fora do teatro Politeama, tentando atrapalhar a leitura de sua plataforma.

$\mathrm{Na}$ batalha simbólica, travada principalmente nos discursos públicos e nos jornais, os dois lados acionavam as referências difusas no imaginário. Se os marcelinistas louvavam em Rui o salvador da pátria, os seabristas recorriam a um tema mais propriamente baiano: a Bahia como mãe amorosa e Rui como filho ingrato, que nunca se aproveitava das altas posições que ocupava no plano federal para levar benefícios à sua terra natal:

Que importa à mãe amante lhe tenha dado o destino um filho glorioso, se este fecha o coração e o afeto como a dizer-lhe: não faço caso de ti, porque de ti não preciso? Que orgulho pode ter a mãe faminta pelas glórias do filho potentado que, ainda cheio de ouro e de valor, não se lembrou um só dia de que havia misérias e amarguras na mansidão do seu primeiro lar? Melhor, de fato, seria ao sentimento materno o filho humilde, cujos extremos a acarinhassem com amor e que, marchando pelas estradas da vida, jamais perdesse de vista o berço de onde saiu. (GAZETA DO POVO, 11 jan. 1910)

Em Salvador, a atmosfera carregada de mobilização política da época da campanha civilista se intensificou com a ocorrência de um tumulto urbano de grandes proporções. Em 5 de outubro de 1909, uma multidão enfurecida com o atropelamento de um cego por um bonde 
da Light depredou veículos, entrou em confronto com a polícia e com funcionários da companhia. Um engenheiro estrangeiro atirou de revólver contra a multidão, que reagiu a pedradas. A estação do Gasômetro foi palco de uma batalha sangrenta, da qual saiu morto um homem, por arma de fogo. A maioria dos revoltosos era formada por carregadores e pescadores do Cais Dourado, onde ocorreu o atropelamento. Segundo a Gazeta do Povo (06 out. 1909), era a primeira vez que o "ordeiro e pacífico" povo baiano se engajava em uma manifestação do tipo, mais comum no Rio de Janeiro. Apesar de justificar inicialmente a revolta, por conta de suas desavenças com a Light, o jornal seabrista condenou a violência demonstrada, que envolveu uma zona importante da cidade "na maior anarquia, como se fora uma revolução”.

Uma semana depois, estourou a greve que paralisou a rede ferroviária baiana. Os primeiros trens a parar foram os da ferrovia Bahia ao São Francisco, mas o movimento acabou envolvendo várias linhas. A greve afetou por quase um mês o fluxo de passageiros e mercadorias entre a capital e o interior. $\mathrm{O}$ abastecimento de carne em Salvador foi diminuído, pois era impossível trazer gado de Mata de São João na rapidez necessária sem os trens. Os grevistas conseguiram se fazer ouvir e tiveram as suas reivindicações atendidas logo no primeiro dia, mas a paralisação prosseguiu com a adesão de lideranças políticas de cidades atravessadas pela ferrovia, como o coronel Carlos Pinto, de Pojuca, e o cônego José Alfredo de Araújo, de Alagoinhas. Com isso, ampliou-se o escopo das reivindicações, exigindo-se redução de tarifas e mudança da direção da rede ferroviária. $\mathrm{O}$ transporte só foi restaurado após tensas negociações, que exigiram a intermediação de um emissário do governo federal.

A tensão política não se expressou, contudo, em quantidade de votos. Apenas 698 mil brasileiros votaram em 1º de março de 1910, o que equivale a cerca de $3 \%$ da população. O percentual cai para 2,7\% se computados somente os votos válidos. (CARVALHO, 2002) O resultado da eleição não surpreendeu. Venceu o candidato com maior força nacional, isto 
é, o marechal Hermes, embora a diferença de votos tenha sido a menor verificada em uma eleição presidencial brasileira até então. Hermes teve $57,9 \%$ dos votos, uma margem pequena se comparada à do antecessor, Afonso Pena, que recebeu 97,9\% dos votos. Rui ainda teve energia para contestar o resultado no Congresso, sem sucesso. Apesar de seu esforço, era o marechal Hermes quem comandaria a política brasileira nos anos seguintes, para grande satisfação e esperança dos que apoiaram sua candidatura na Bahia, como o deputado federal J. J. Seabra.

\section{A ascensão do seabrismo e o bombardeio de Salvador (1911-1912)}

Seabra não tardou em organizar suas forças para o combate. $\mathrm{O}$ embrião do seu novo partido germinou ainda na campanha hermista: era a Junta Baiana Pró-Hermes-Venceslau, fundada em julho de 1909. Em fevereiro de 1910, Seabra fez duas excursões ao interior da Bahia para buscar adesões. Na primeira, de trem até Alagoinhas (onde seu filho era promotor), confraternizou com dois líderes do movimento de outubro de 1909 , coronel Carlos Pinto e padre Alfredo, e seguiu até as oficinas da ferrovia, em Aramari, em "gratidão aos laboriosos operários" que, segundo ele, o apoiavam. A segunda viagem deveria incluir Cachoeira, São Félix, Castro Alves, São Gonçalo dos Campos, Feira de Santana e Cruz das Almas, mas foi interrompida em Castro Alves após um grande tumulto que acabou em bengaladas e tiroteio. Segundo Seabra, a agressão foi provocada por policiais instigados por políticos civilistas (os irmãos Bernardo e Rafael Jambeiro).

Em 15 de março de 1910, a Junta Hermes-Venceslau transformou-se no Partido Democrata, em Assembleia no palacete Devoto. Apesar dos esforços dos seabristas, que telegrafaram a todos os municípios baianos informando que o novo partido contava com o apoio do governo federal, a agremiação não conseguiu reunir as maiores forças políticas do estado 
nesse primeiro momento. Para os chefes municipais, a situação do governo estadual ainda não estava tão desesperada que os impelisse aos braços de Seabra, abrindo espaço para as oposições locais se articularem aos marcelinistas no poder. O panorama estava indefinido. Vários cenários pareciam possíveis de se concretizar. Os marcelinistas poderiam fazer as pazes com o hermismo triunfante, aproveitando o fato de que, após as eleições e a batalha pelo reconhecimento, Rui saiu de cena para cuidar da saúde. Também era possível que Hermes resolvesse apoiar as pretensões dos severinistas, que tinham bases mais enraizadas na política baiana. Nada indicava, de forma inequívoca, que o Partido Democrata tivesse um futuro promissor.

$A$ ata de fundação do partido registra a adesão de 75 representações municipais, o que significa mais da metade dos 128 municípios existentes na Bahia (GAZETA DO POVO, 16 mar. 1910). Parte desses "representantes”, porém, não tinha poder nas municipalidades, e constava apenas para criar volume. Dentre os que se destacavam pelo maior peso político, estava o coronel Antônio Pessoa da Costa e Silva, de Ilhéus, que, desde o início do século, vinha combatendo a influência do coronel Domingos Adami de Sá. Este contava com apoio do governo estadual e controlava a intendência municipal através do correligionário João Mangabeira. Antônio Pessoa apostou cedo na alternativa do seabrismo, tornando-se membro do Partido Democrata. A adesão lhe rendeu ótimos frutos, posteriormente, contribuindo para consolidar seu mando regional.

Com dificuldades em arregimentar chefes poderosos, Seabra teve que se unir ao conselheiro Luís Viana, que retornava do ostracismo. Dez anos antes, Viana deixou o governo hostilizado pelo comércio de Salvador, desmoralizado pelas derrotas da polícia em Canudos e rompido com o sucessor, Severino Vieira. Ainda assim, era um ex-governador, nome tradicional da política, com influência no interior da Bahia, onde o seabrismo não tinha muitas raízes. A aliança Seabra-Viana era, entretanto, precária em sua essência, pois ambos almejavam para si o controle da política estadual. (SAMPAIO, 1998) 
À primeira vista, a composição social da agremiação seabrista não diferia substancialmente dos demais partidos baianos. Dos nove integrantes da comissão executiva, mais alta instância do partido, cinco eram apresentados como doutores, três como coronéis e um como comendador. No conselho geral, de acordo com uma lista da Gazeta do Povo (16 mar. 1910), apenas dois dos oitenta membros não traziam qualquer título acompanhando o nome. Os demais se dividiam em: formação superior (33), formação religiosa (3), títulos da Guarda Nacional (35) e distinções honoríficas, como comendador, desembargador e conselheiro (4). ${ }^{3} \mathrm{Um}$ olhar mais atento sobre os nomes revela, contudo, certas especificidades. $\mathrm{Na}$ comissão executiva, era destacada a presença de grandes comerciantes, como o comendador João Umbelino Gonçalves e os coronéis José Lopes de Carvalho e Deraldo Dias. No conselho geral, havia, pelo menos, um representante dos trabalhadores urbanos: o capitão Domingos Silva, do Centro Operário, que tinha ligações com Seabra desde 1903. São indícios do fenômeno já comentado: diante da dificuldade em obter o apoio dos chefes tradicionais da Bahia, Seabra recorreu ao comércio e aos trabalhadores da capital, setores dotados de grande visibilidade política.

O programa do Partido Democrata fazia referências explícitas aos trabalhadores, ao postular a "solução do problema operário, visando, principalmente, três questões: as habitações operárias; a educação do operário e de seus filhos; e a proteção aos operários vítimas dos acidentes no trabalho". No caso da moradia e da educação, atendia-se também ao desejo de "civilização", pois a educação disciplinaria os costumes populares e a construção de casas facilitaria a remoção dos cortiços e outras formas de moradia consideradas insalubres e feias. Quanto aos acidentes de trabalho, reivindicação precursora das demais leis de proteção ao trabalhador, tratava-se de um pon-

3 A lista da Gazeta do Povo, na verdade, traz quatro nomes sem títulos, mas dois deles puderam ser identificados: o médico Virgílio Martins dos Reis e o capitão Domingos Silva. Eles foram incluídos, então, nas categorias de formação superior e Guarda Nacional, respectivamente. É possível que haja outras imprecisões semelhantes na fonte, mas que não chegam a comprometer as inferências gerais sobre a composição do partido seabrista. 
to mais delicado, pois não contava com o apoio da maior parte dos patrões, a quem não interessavam quaisquer restrições à "liberdade de trabalho".

A referência aos operários no programa, sem citação de outras "classes", foi alvo de críticas. A Gazeta do Povo (07 abr. 1910) explicou que o partido desejava "assentar os alicerces sobre que se terá de edificar o progredimento de todas as classes", e que "apenas foi aberta exceção para a classe operária, que muito de perto nos interessa, que é a preocupação de todos nós, burguesia que dela vivemos, haurindo-lhe nossas forças, e que já mereceu as atenções muito particulares do presidente do partido, quando ocupou o cargo de ministro do interior no benemérito governo do Sr. Rodrigues Alves”. O jornalista referia-se aos projetos do ex-ministro Seabra para construção de casas populares, mas o que sobressai no texto é a nítida identificação de classe: "todos nós”, burguesia independente de coloração partidária, precisamos nos preocupar com "eles", os operários, pelo bem da estabilidade social.

Dois temas nacionais aparecem no programa do partido, apesar de seu alcance ser meramente estadual. Um deles era a necessidade de promulgação do Código Civil, o que parece ter sido uma alfinetada em Rui, a quem se atribuía o atraso da promulgação dessa lei. Mas havia também uma referência ao "desenvolvimento dos processos para a defesa militar do país”, que se relacionava a questões políticas mais concretas, pois Seabra vinha buscando apoio dos militares para sustentar sua ascensão ao governo da Bahia, como se verá adiante.

Apesar da presença de comerciantes e trabalhadores, a linha de frente do Partido Democrata era composta por "doutores" de origens variadas. Os primos Antônio Ferrão Muniz de Aragão (Antônio Muniz) e Antônio Muniz Sodré de Aragão (Muniz Sodré), por exemplo, tinham longa genealogia nos engenhos do Recôncavo. Ernesto Simões Filho vinha de uma família de posses, mas sem evocações de nobreza: seu pai era um coronel de Cachoeira, que se tornou proprietário da próspera farmácia Galdino, em Salvador, pelo casamento. Otávio Mangabeira 
tinha poucos recursos financeiros, mas bons contatos sociais, situação parecida com a do próprio Seabra, quando iniciou sua carreira. Em comum, além do grau de doutor, todos esses elementos centrais do seabrismo eram jovens: em 1910, Antônio Muniz tinha 35 anos; Muniz Sodré, 29; Simões Filho e Otávio Mangabeira, 24. Eram homens de uma nova geração, que se iniciava na política pelas mãos do experiente Seabra, então com 55 anos de idade. Os adversários os chamavam, ironicamente, a "petizada" ou os "diabretes" de Seabra. (A BAHIA, 03 set. 1909)

A definição dos rumos da política baiana dependia da força do governo federal. Em outubro de 1910, a balança parecia pender para o lado de Severino Vieira, pois seu candidato a uma vaga de deputado federal pela Bahia, Augusto de Freitas (cunhado e desafeto de Seabra) foi reconhecido no Congresso. Seabra, que defendia a anulação da eleição (o que mostra que ele não tinha esperança de reconhecer seu candidato, o vianista José Eduardo Freire de Carvalho Filho), sofreu a derrota e perdeu o posto de líder do governo na Câmara.

Menos de um mês depois, no entanto, na posse do presidente Hermes (15 nov. 1910), Seabra foi o único baiano escolhido para compor o ministério. A explicação para essa aparente contradição reside na heterogeneidade do hermismo que, após o triunfo eleitoral, começava a vir à tona. Severino Vieira contava com o apoio de Pinheiro Machado, que continuava forte no Congresso. Seabra, por sua vez, havia se articulado ao grupo que desejava diminuir a influência de Pinheiro, formado por militares salvacionistas e parentes do presidente, como o tenente Mário Hermes (filho), o deputado federal Fonseca Hermes (irmão) e o general Clodoaldo da Fonseca (primo). Os adversários insinuavam que havia uma "condição política" para a escolha de Seabra para o ministério: a futura eleição do jovem Mário Hermes como deputado federal pela Bahia, o que realmente viria a ocorrer. ${ }^{4}$

4 Oriundo de uma família de militares, Mário Hermes nasceu no Ceará enquanto seu pai servia naquele estado, mas não tinha ligação com grupos políticos estaduais até sua aliança com Seabra. Ele foi deputado federal pela Bahia durante todo o período seabrista (19121923). Depois não conseguiu mais se eleger. Sua trajetória política foi tributária da importância de seu pai e da sua ligação com Seabra. Na Bahia, vinculou-se através do seabrismo 
A pasta da Viação e Obras Públicas pulsava de interesse político e econômico. Tinha sob seu controle o desenvolvimento das ferrovias e portos, além das obras públicas. Assim que assumiu o ministério, Seabra entrou a criar polêmica. Adotando um discurso de moralização, rescindiu contratos firmados pelo antecessor, despertando a ira do jornal $O$ País, que até então o apoiava. Foi essa a revisão contratual citada no segundo capítulo. Um dos contratos cancelados era de interesse do conde Modesto Leal, aliado de Pinheiro Machado. Apesar disso, Seabra e Pinheiro mantinham-se em aparente cordialidade. Na Bahia, os seabristas diziam ser os representantes do Partido Republicano Conservador (PRC), criado por Pinheiro. Não era interessante, para nenhum dos lados, um rompimento explícito naquele momento.

De volta à posição de ministro, Seabra não tardou em fazer valer sua força no estado natal. Em primeiro lugar, acionou os expedientes usuais da política: demitiu funcionários federais ligados aos seus adversários da Bahia para dar lugar aos aliados. A direção regional dos Correios e Telégrafos, por exemplo, foi entregue a Simões Filho. Em seguida, Seabra começou a pressionar os governistas baianos para abrir espaço para seu grupo político. A primeira grande ação nesse sentido ocorreu em 1911, nas eleições para a Câmara e o Senado estadual. Como sempre, os governistas ficaram com a maior parte das vagas, dando origem a protestos da oposição. Esses protestos eram comuns e não costumavam preocupar o governo. Mas, em 1911, os seabristas tinham acesso a argumentos mais persuasivos do que meras palavras.

Enquanto se fazia a "verificação" da eleição, uma comissão de militares veio a Salvador para "inspecionar" os canhões do Forte de São Marcelo, que foram direcionados para a cidade. Ao mesmo tempo, anunciava-se que o scout Bahia, um dos novos navios de guerra do país, viria à capital baiana para receber uma baixela de prata. Os pretextos não disfarçavam a ameaça

aos líderes do Centro Operário e, em 1912, presidiu o Congresso Operário Nacional, que seu pai organizou no Rio de Janeiro.

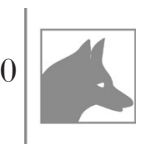


óbvia sobre o governo estadual. O clima de tensão se espalhou pela cidade. A Babia (24 mar. 1911) publicou um soneto jocoso, que se revelaria profético:

\section{Ave São Marcelo}

Vai servir afinal o forte S. Marcelo

Servir de tribunal para a Bahia...

Já não é mais das horas o martelo

Com a sua carunchosa artilharia

Ele que estava ali qual cogumelo

E que inútil a todos parecia,

Remoçará, entrando ativo e belo,

Do Pro-nobis na pândega arrelia

Assim dizem os moços da Gazeta,

Pintando a coisa seriamente preta,

Fazendo um dreadnought do empadão...

Reviverão os jovens democratas

A velha frase chata entre as mais chatas:

O direito na boca do canhão!

Rui Barbosa estava, na época, passando uma temporada em São Paulo, mas era informado sobre a crise baiana pelo filho, o deputado federal Alfredo Rui. A correspondência entre os dois dá uma ideia das dificuldades daquele momento político. Em 12 de março de 1911,

5 O forte de São Marcelo era acionado toda noite para dar o "tiro das nove", avisando da hora de dormir. Por isso, ele era o martelo das horas. "Pro-nobis" era como os adversários chamavam os seabristas, como referência aos benefícios que eles buscavam na política. "Empadão" foi o apelido dado ao forte de São Marcelo por D. Pedro II, por sua forma circular e bojuda. "Dreadnought", ou encouraçado, eram os poderosos novos navios de guerra da Marinha brasileira. 
Alfredo Rui avaliava que era necessário "estabelecer na Bahia um modus vivendi com o Seabra”, que pudesse evitar a intervenção no estado, “já tão enfraquecido pela política desorientada e pusilânime dos nossos amigos políticos locais". O filho de Rui informava que o general Sotero de Meneses, chefe da guarnição militar na Bahia, era seabrista fervoroso e prometia cumprir "qualquer ordem à risca", pois se sentiria feliz em "demonstrar ao seu amigo Seabra o quanto the era reconhecido e grato". Alfredo Rui considerava melhor negociar uma solução, pois o confronto armado levaria à "perda total e completa do nosso predomínio no estado". Ele declarou, ainda, não acreditar que Seabra desejasse realmente a intervenção. Em sua opinião, o ministro preferia "conseguir o que almeja pelos meios naturais". (FCRB/ARB/CRUPF 141.1/1 12/03/1911, grifo no original)

Seabra propunha aos governistas baianos que lhe cedessem um terço das cadeiras na Câmara Estadual e uma vaga no Senado Estadual. Queria, também, segundo Alfredo Rui, que a bancada baiana na Câmara Federal não o hostilizasse, nem ao marechal Hermes, "afim de que ele, com Pernambuco, Bahia e São Paulo, dê o tombo no Pinheiro". Já se vê que Seabra buscava cooptar o apoio de Rui para seus planos anti-Pinheiro, mas não foi bem sucedido. A correspondência de Alfredo Rui indica, ao contrário, que a ideia de resistir se fortaleceu. Araújo Pinho disse dispor de "mil e tantos homens de polícia bem treinados" na capital e que, se não fosse possível tecer um acordo honroso, "não se afastaria do dever" de lutar. Depois de várias idas e vindas, o governo estadual acabou cedendo, no dia 29 de março, diante da ameaça do Exército. Seabra obteve as vagas na Câmara e no Senado Estadual. Fiel ao seu estilo, prometeu arranjar cargos federais para os candidatos governistas que tivessem que perder a vaga para a entrada dos seus partidários. (FCRB/ARB/CRUPF 141.1/1 12/03/1911 a 30/03/1911)

O chamado "acordo de 1911" foi o passo decisivo de Seabra rumo ao domínio da política baiana. A partir de então, a balança começou a pender definitivamente para seu lado. Choviam adesões de políticos 
da capital e do interior: Antônio Calmon, Deocleciano Teixeira, José Aquino Tanajura, José Álvaro Cova, Campos França, Arlindo Leoni, barão de São Francisco, barão do Açu da Torre, entre outros. Quanto mais forte o ministro Seabra se mostrava, mais adesões recebia, o que o fortalecia ainda mais. Em junho, o jornal Diário de Notícias (BA) lançou a candidatura seabrista ao governo da Bahia, na eleição programada para o ano seguinte. Dias depois, Severino Vieira rompeu com o hermismo, que não o vinha prestigiando. $\mathrm{O}$ próprio Pinheiro Machado declarou estar "exultante" com a lembrança do nome de Seabra para o governo baiano. $\mathrm{O}$ astuto senador gaúcho, provavelmente, preferia ter o baiano bem longe, em sua terra natal, do que articulando planos para derrubar sua influência na capital federal.

Em julho de 1911, os baianos que ainda se mostravam céticos quanto ao prestígio de Seabra testemunharam um espetáculo surpreendente. A pretexto da comemoração do centenário da Associação Comercial da Bahia e da inauguração de um trecho do porto, Seabra articulou uma visita do marechal Hermes a Salvador. O presidente não veio sozinho, e sim acompanhado dos mais modernos navios da Marinha brasileira. A mobilização da esquadra para uma espécie de desfile marítimo, da baía de Guanabara à baía de Todos os Santos, era algo nunca visto no país. Hermes, Seabra e a comitiva viajaram no poderoso encouraçado São Paulo. Para deixar bem claro que a iniciativa de trazer o presidente era sua, não do governador Araújo Pinho, Seabra fez com que Hermes fosse hospedado pela Associação Comercial, e não pelo governo estadual, que foi apenas "comunicado" da vinda do marechal.

Os adversários do seabrismo não pouparam críticas à visita presidencial. A mais criativa partiu de Severino Vieira, para quem Seabra veio exibir Hermes tal como se exibe um urso amestrado em uma feira de variedades. Rui Barbosa também não perdeu a oportunidade de comentar o caso, salientando os gastos desnecessários (ele listou a quantidade de garrafas de cerveja, champanhe e vinho do porto levadas 
a bordo) e o papel ridículo a que o presidente submeteu a Marinha, para prestigiar o ministro da Viação, um baiano "rebelde, rouquejante, rabigo e rugidor”. (BARBOSA, 1911, v. 38, t. 1, p. 170-215; 1911, v. 38, t. 3, p. 64)

Após a campanha civilista, Rui havia se retirado da política para descansar, mas retornou em fins de 1910 em meio ao debate sobre o movimento dos marinheiros, atualmente conhecido como a Revolta da Chibata. Em 1911, intensificou sua oposição ao hermismo, cobrando a punição dos responsáveis pelo massacre da Ilha das Cobras e pela chacina ocorrida no navio Satélite. Com discursos e artigos jornalísticos impecavelmente construídos, Rui mobilizava a opinião pública contra as violências do governo, que parecia dar razão aos seus alertas da época da campanha eleitoral. Novamente, ele era a voz mais potente da oposição, principalmente no Senado e no Diário de Notícias (RJ). Em retaliação por essa postura combativa, seu genro Batista Pereira e seu cunhado Carlito perderam seus empregos públicos, o que enfureceu ainda mais o senador baiano. Anos depois, ele ainda lembrava da atitude de Hermes, que demitiu o marido de sua filha quando ela estava adoentada. "O golpe do marechal poderia ter-nos custado a vida de minha filha”, protestou, de maneira um tanto dramática. No lugar do genro de Rui, foi nomeado o enteado de um ministro hermista. Era o mundo dos bastidores, que nunca estava muito distante das luzes da ribalta política. (BARBOSA, 1913, v. 40, t. 4, p. 195)

O lançamento da candidatura Seabra puxou a atenção de Rui para as questões baianas. Em diversos artigos, ele argumentou que o ministro da Viação era inelegível para o governo da Bahia por não morar no estado por mais de dez anos. (BARBOSA, 1911, v. 38, 1911, t. 3, p. 61) Enquanto isso, os governistas baianos, reforçados pelos severinistas, tentavam articular uma candidatura que agregasse todos os não seabristas e ainda contasse com a boa vontade do marechal Hermes. Escolheram o deputado Domingos Guimarães. Não é preciso explicar muito sobre porque a escolha desagradou Rui: era um hermista. O senador propôs 
outros nomes, como o do deputado federal José Maria Tourinho, mas seus aliados baianos sabiam que escolher alguém ligado a Rui seria um agravante para a fúria do governo federal, que vinham tentando aplacar.

Para reforçar o impedimento legal à candidatura seabrista, Rui passou aos aliados a minuta de uma nova lei estadual sobre inelegibilidades, que foi aprovada. Com a mudança, Seabra teria que desistir do ministério quatro meses antes do pleito, se desejasse concorrer ao governo baiano. Seabra não saiu do ministério, nem desistiu da candidatura. Nada disso poderia barrar mais a marcha avassaladora do ministro da Viação, que parecia decidido a tomar o controle da política da terra natal a qualquer custo.

Em novembro de 1911, instaurou-se uma grave crise política em Pernambuco, com a disputa de dois hermistas pelo governo estadual. Os partidários do general Dantas Barreto acionavam o discurso anti-oligárquico para expurgar o grupo do senador Rosa e Silva, encastelado no poder desde 1896. O chefe pernambucano, que não queria ir com Rui "nem para o céu", agora descia aos infernos da rejeição hermista. Em dezembro, uma intervenção militar assegurou a posse de Dantas Barreto, ex-ministro da Guerra. A interferência do presidente Hermes em favor dos seus aliados nos estados tornava-se uma possibilidade muito concreta, palpável. $\mathrm{O}$ desenrolar da crise pernambucana teve um impacto extraordinário na Bahia. De uma hora para outra, os seabristas começaram a falar em combater oligarquias. A Gazeta do Povo (30 nov. 1911) chegou a publicar um artigo intitulado "A oligarquia estrebucha", em que explicitava sua nova compreensão do termo, recorrendo à autoridade de Quintino Bocaiuva:

Não é somente o regime indecoroso de famílias que constitui as oligarquias, disse recentemente [...] o venerando prócer da República e do Partido Republicano Conservador, o senador Quintino Bocaiuva: igual regime impera em qualquer dos estados, acrescentou s.EX., "onde o conluio de compadres explora em seu proveito as vantagens da administração pública, de que o povo se vê segregado em toda a parte”. 
À luz desse critério [...], o regime que se implantou com o nefasto governo do Sr. Severino Vieira [...] caracteriza-se a toda evidência como o das imorais e usurpadoras oligarquias, combatidas por todas as forças vivas da opinião nacional nessa hora de legítima reivindicação dos direitos do povo. (GAZETA DO POVO, 30 nov. 1911)

A nova interpretação dos seabristas era que, desde Severino Vieira, a Bahia vivia sob o domínio de uma nefasta oligarquia, de um governo de "compadres" - a referência ao compadrio era especialmente acionada, pois esse laço existia entre José Marcelino e Araújo Pinho, e também entre Araújo Pinho e Domingos Guimarães. Excluía-se, evidentemente, o governo de Luís Viana, aliado de Seabra. Ainda em novembro, alguém que assinava com o nome Benjamim publicou a seguinte convocação, na seção ineditorial da Gazeta do Porv:

Povo!

É tempo de sacudir para longe essa atitude opressora, de um governo sem ação que está sendo cavalgado pelo Sr. Severino Vieira, o único responsável pela maior parte da infelicidade da Bahia!

Preparai as vossas armas para repelir a miserável falsificação de atas que um governo derrotado está organizando.

O eleito da Bahia, o único que pode agora fazer a felicidade de nossa terra, é o engenheiro Júlio Brandão.

Não recuar, deve ser o lema de um povo cansado de sofrer.

A Bahia empossará a Júlio Brandão e aos dez conselheiros conservadores, eleitos triunfantemente por brasileiros que não devem ser ludibriados.

Alerta, baianos! Imitai aos heróis de Pernambuco, aquela porção de bravos que agora acabam de dar o maior exemplo de civismo.

Viva o povo baiano! (GAZETA DO POVO, 17 nov. 1911) 
O candidato seabrista à intendência de Salvador, Júlio Viveiros Brandão, era o gerente da Linha Circular, uma das duas empresas de bonde dos Guinle na capital baiana. A escolha deu margem a críticas dos adversários, que alertavam para o risco de Salvador se transformar em um "Panamá municipal", ${ }^{6}$ com o açambarcamento dos serviços pela companhia. Segundo artigo do Correio da Manhã (RJ), reproduzido n'A Babia (11 nov. 1911), os Guinle despenderam mais de cem contos de réis na eleição, preparando um "terrível assalto ao patrimônio do município e aos bolsos do contribuinte, enquanto não chega a vez de estender até os cofres do Estado e às riquezas naturais da Bahia os tentáculos famélicos da abominável pieuvre”. A metáfora do polvo (pieuvre) era novamente acionada para simbolizar o poder sufocante das grandes corporações, nessa etapa do capitalismo mundial.

O adversário de Júlio Brandão era João Pedro dos Santos, lançado pelos marcelinistas com apoio dos severinistas. Segundo os seabristas, ele tinha apoio da Light e da Eclairage, ambas do grupo Light, de Farqhuar. A Gazeta do Povo (04 nov. 1911) denunciou que as duas empresas estariam pressionando seus funcionários para votar no candidato, interessadas nas concessões públicas de energia, transporte e outros serviços. Como se vê, a disputa pela intendência de Salvador envolvia importantes interesses econômicos.

A eleição municipal, realizada em 12 de dezembro, foi motivo para a escalada das animosidades. A apuração foi extremamente tumultuada. A certa altura, o general Sotero de Meneses resolveu "acalmar os ânimos" passeando com um pelotão de cavalaria em frente à Câmara Municipal, o que foi interpretado como ameaça aos partidários de João Santos, pois o general era ligado aos seabristas. Estes, por sua vez, denunciavam ações violentas da polícia estadual, reforçada por jagunços, mandados à capital por chefes governistas do interior. Cada um dos lados proclamou seu próprio intendente e Conselho Municipal, configurando uma "duplicata”. A pressão sobre o governo estadual era insuportável e, em 22 de de-

\footnotetext{
6 Referência aos escândalos de suborno e desvio de dinheiro que vieram à tona durante o processo de construção do Canal do Panamá por grandes grupos capitalistas. Em 1911, o canal ainda não estava concluído.
} 
zembro, o governador Araújo Pinho renunciou. Seu primeiro substituto legal, o cônego Manuel Leôncio Galrão, presidente do Senado Estadual, alegou problemas de saúde para não assumir o cargo, que foi para as mãos do presidente da Câmara, o deputado estadual Aurélio Viana.

A renúncia de Araújo Pinho foi o ato deflagrador de uma estratégia ousada, que parecia a única saída para resistir à pressão do governo federal. O plano foi elaborado por Rui. Consistia na convocação da Assembleia Estadual em uma cidade do interior, longe do alcance dos canhões e dos navios de guerra, sob controle de chefes aliados locais com seus jagunços. O local escolhido foi Jequié. Segundo o próprio Rui, que tentava negar que a cidade fosse distante e isolada, o transporte da capital a Jequié levava "apenas" um dia e meio: primeiro, quatro horas de barco a Nazaré, depois, oito horas de trem a Santa Inês, mais um trecho que deveria ser vencido a pé ou a força animal. Conforme Rui, esse pedaço final se compunha de "14 léguas de bons caminhos, de boas estradas, caminhos que qualquer peão daqueles sertões faz, sem cansaço, em uma noite”. Jequié também não tinha telégrafo, pois a linha era interrompida em Santa Inês. Tratava-se, seguramente, de um lugar remoto, onde o governo estadual poderia assegurar os resultados que o manteriam no poder. (BARBOSA, 1912, v. 39, t. 1, p. 69, 160)

A partir da convocação da Assembleia Estadual para Jequié, no primeiro dia de mandato do novo governador Aurélio Viana, os acontecimentos se precipitaram. Os seabristas da Câmara e do Senado Estadual, cada vez mais numerosos com o evidente fortalecimento do ministro, queriam manter a Assembleia em Salvador. Eles alegavam que a mudança de sede teria que partir dos parlamentares, e não do governador, como aconteceu. Começou, então, uma batalha jurídica, durante a qual os seabristas obtiveram do juiz federal instalado na Bahia, Paulo Martins Fontes, um habeas corpus garantindo sua entrada no prédio da Câmara, que vinha sendo guardado pelas forças do governo. Foi esse o estopim do bombardeio. 
No dia 10 de janeiro de 1912, os seabristas, liderados pelo presidente do Senado Estadual em exercício, o barão de São Francisco (que assumiu na ausência do cônego Galrão), marcaram uma reunião preparatória da Assembleia Estadual, a qual pretendiam fazer funcionar em Salvador à revelia do decreto de mudança para Jequié. $\mathrm{O}$ prédio da Câmara, onde a Assembleia deveria funcionar, estava fechado e cercado pela polícia. Os seabristas apelaram para o general Sotero de Meneses, para que ele fizesse cumprir a ordem de habeas corpus. O general deu um ultimato a Aurélio Viana: se o governador não liberasse o prédio, os militares entrariam em ação. Diante da resposta negativa, mandou distribuir o seguinte boletim:

$7^{\text {a }}$ região militar $-\mathrm{O}$ general Sotero de Meneses, inspetor da 7a região militar, faz saber que, tendo o governo do Estado se recusado terminantemente a obedecer ao habeas corpus concedido pelo Exmo Sr. Juiz seccional, para que possam funcionar livremente, no edifício da Câmara dos Deputados, os congressistas convocados pelo Exmo. Sr. barão de São Francisco, presidente em exercício do Senado, cumpre-lhe, em obediência à requisição do mesmo juiz federal, aos poderes competentes da República, fazer respeitar e executar essa ordem de intervenção da força de seu comando, intervenção a que se dará início dentro de uma hora. (GAZETA DO POVO, 17 jan. 1912)

Às $13 \mathrm{~h} 30$, dois tiros de pólvora seca foram dados como advertência e, em seguida, o forte de São Marcelo começou a bombardear Salvador, instaurando o pânico na cidade. Além do "forte do mar", o forte do Barbalho também participou do ataque, em balaços convergentes que visavam destruir a resistência da polícia estadual, cujas forças estavam concentradas no centro da cidade. É difícil determinar com precisão o saldo da destruição, pois os relatos divergem de acordo com a filiação política das testemunhas, mas é certo que a tarde de 10 de janeiro de 1912 marcou um dos mais violentos e extraordinários acontecimentos da história da Bahia.

O palácio do governo foi incendiado e a biblioteca pública, que ali estava instalada, foi destruída. Livros da época colonial foram perdidos para sempre. O número de feridos e mortos é controverso. Os seabristas, evi- 
dentemente, minimizaram os danos. Segundo eles, os estragos no palácio foram causados por um incêndio posterior, provocado por um partidário do governo. A polícia estadual é que estaria atirando no povo e nos soldados, por isso a população estaria aprovando a ação militar. O general Sotero afirmou que o bombardeio havia sido uma "medida humanitária", para evitar que os soldados entrassem em luta corporal contra os policiais, reduzindo as baixas de ambos os lados. (GAZETA DO POVO, 12 jan. 1912)

Uma versão bem diferente foi narrada, por exemplo, pelo jornalista baiano Almáquio Diniz, em carta a Rui Barbosa, que o senador leu em um discurso no Supremo Tribunal Federal. Conforme Diniz, após o pandemônio do bombardeio, com a destruição de prédios públicos e a danificação de casas particulares (segundo ele, parte dos projéteis foram direcionados para as residências de José Marcelino e Domingos Guimarães), o governador pediu uma trégua ao general. Foi nessa hora, segundo ele, que os soldados espalharam o terror pela cidade em cenas de carnificina. Um grupo teria invadido a diretoria de rendas do Estado e matado quinze policiais lá abrigados, ainda nessa mesma noite. (BARBOSA, 1912, v. 39, t. 1, p. 49-51)

A violência inusitada do bombardeio ficou marcada profundamente na alma da cidade, mas os tumultos não ficaram restritos às ocorrências de 10 de janeiro. Até 28 de março, quando Seabra tomou posse do governo do Estado, Salvador viveu um período de turbulência. Aurélio Viana teve que abandonar o governo em 12 de janeiro, sob pressão de uma multidão enfurecida. Refugiou-se no consulado da Venezuela, depois fugiu à noite para o da França, onde uma comissão liderada pelo deputado Simões Filho foi buscar sua renúncia. O governo foi entregue, então, a Bráulio Xavier, presidente do Tribunal da Relação e quarto substituto legal do governador. Mas, com a repercussão dos eventos baianos na capital federal, especialmente pela palavra de Rui, Aurélio Viana acabou assumindo novamente o governo em 21 de janeiro, para renunciar mais uma vez, quatro dias depois. De volta ao cargo, Bráulio 
Xavier organizou as eleições que, sem surpresa, deram vitória aos novos donos do poder na Bahia.

Do Rio de Janeiro, Rui liderou a resistência ao seabrismo. Logo após a renúncia de Araújo Pinho, ele pronunciou uma série de quatro discursos no Senado sobre o "caso da Bahia", defendendo a legalidade da mudança da Assembleia para Jequié e protestando contra a ousadia do governo Hermes em interferir na autonomia estadual. Depois do bombardeio, publicou vários artigos no Diário de Notícias (RJ), entre eles o magistral "Caim" (02 fev. 1912), em que um diabólico Seabra era levado a uma espécie de tribunal divino por ter assassinado seus irmãos e maltratado a Bahia, sua mãe. $\mathrm{O}$ texto teve impacto nacional e marcou a imagem de Seabra para sempre. Em outros artigos, Rui apelou para os paulistas, seus antigos aliados na campanha civilista, para que socorressem a Bahia, alertando que, se nada fosse feito, São Paulo poderia ser a próxima vítima do governo federal. Os chefes paulistas, porém, entraram em acordo com os hermistas, e nada fizeram em favor dos aliados baianos. (BARBOSA, 1912, v. 39, t. 4)

Rui também levou a luta contra Seabra para os tribunais. No dia 13 de janeiro, entrou com o primeiro dos três pedidos sucessivos de habeas corpus que apresentou nessa época, em favor de Aurélio Viana, Manuel Galrão e outros políticos. Os pedidos foram negados pelos juízes do STF, atendendo ao que desejava o governo federal. Somente um quarto pedido de habeas corpus, que dizia respeito à segurança de Alfredo Rui, Lemos Brito e Virgílio de Lemos, foi deferido. Esse habeas corpus não tinha grandes consequências políticas, pois não dava margem à restituição do governo aos civilistas. Era, portanto, politicamente inofensivo, e os juízes atenderam ao pedido do pai preocupado. Alfredo Rui havia partido para Salvador no dia 10 de janeiro, ainda antes do bombardeio, e chegou no dia 12. Corajosamente, desembarcou na capital baiana mesmo assim. Nos primeiros dias, ainda pôde circular pela cidade com tranquilidade, mas, com o acirramento dos conflitos, tornou-se um alvo preferencial da fúria seabrista. (BARBOSA, 1912, v. 39, t. 1) 
FigURA 4. O oceano se "manifesta" contra o bombardeio

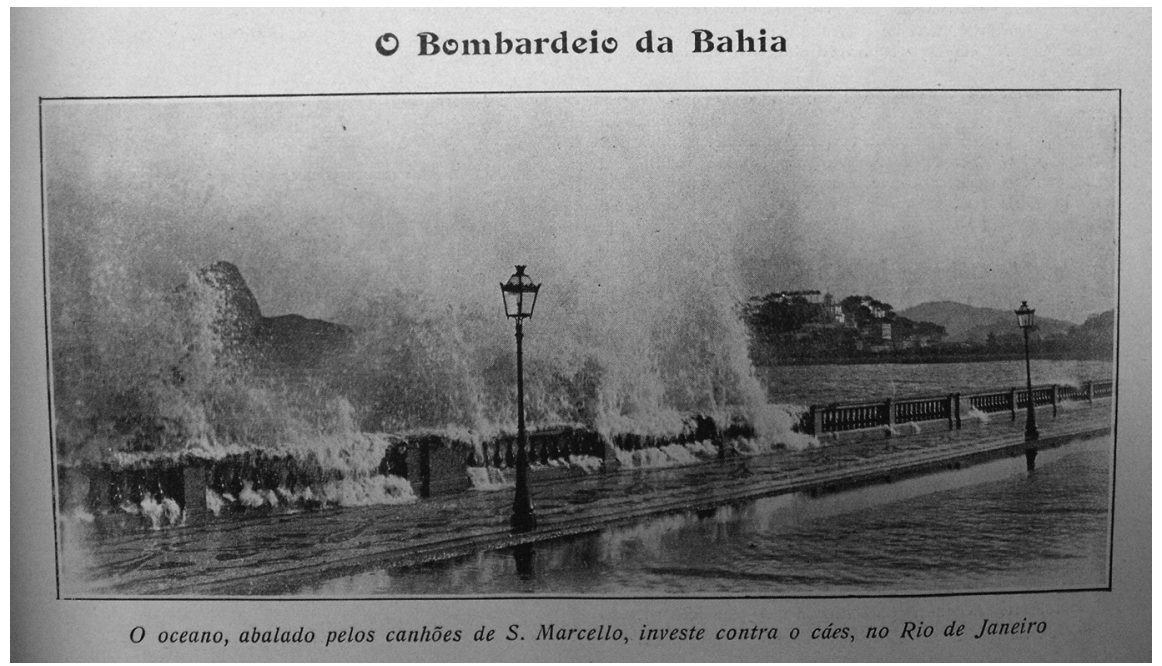

Fonte: Revista Careta, ano 5, n. 190, 20 jan. 1912. Acervo on-line da Fundação Biblioteca Nacional (www.bn.br).

A repercussão nacional do bombardeio foi imensa. Segundo a revista Careta (Figura 4), até o oceano "expressou" sua indignação com os eventos baianos, lançando ondas furiosas sobre a capital federal. No seio do ministério do marechal Hermes, instaurou-se uma crise. $\mathrm{O}$ almirante Marques de Leão, ministro da Marinha, pediu exoneração com uma célebre carta, protestando contra o bombardeio e contra a participação do scout Bahia nos conflitos. De fato, esse navio de guerra, comandado por um oficial vianista, havia aportado novamente em Salvador, servindo de “argumento" extra a favor da dupla Seabra-Viana. O barão do Rio Branco, ministro do exterior, inicialmente acusado por Rui de omissão, aparentemente também protestou contra o ato do general Sotero. $\mathrm{O}$ fato de o barão ter falecido em meio à crise baiana (09 fev. 1912), deu origem à história (provavelmente fantasiosa) de que sua doença fora agravada pela profunda tristeza pelo bombardeio da Bahia, terra natal de seu pai, o visconde do Rio Branco. O barão passou a ser, então, a mais ilustre "vítima" 
dos canhões de São Marcelo. ${ }^{7}$ Veja-se, por exemplo, o dramático relato de Américo Jacobina Lacombe sobre seus últimos instantes de vida:

Agoniado, o doente era removido constantemente da cama para uma cadeira de braços. Estava cego, mas, com os olhos muito abertos, como se estivesse a contemplar alguma coisa distante. Delirava, e as suas palavras indicavam o "delírio profissional" do político, ligadas à impressão do bombardeio:

- Bombardeio da Bahia!

- Forte de São Marcelo! (LACOMBE, 1955, p. 129)

Um dos argumentos usados por Rui para cobrar a punição dos responsáveis pelo bombardeio era que o ato teria afetado a imagem do Brasil no exterior, nossos "foros de país civilizado", pois não se admitia aquele tipo de ataque a uma cidade comercial. A violência despropositada estaria colocando o Brasil no patamar das demais repúblicas sul-americanas, desprezadas pelos políticos brasileiros por seus golpes caudilhescos. Segundo Rui, "na imprensa europeia, se alude já em sobressalto pela sorte dos capitais aqui investidos, à onda de desordem em que se vai atolando a nossa cultura e o nosso crédito". O bombardeio estaria, pois, dando ao Brasil um atestado de barbárie, prejudicando sua capacidade de atrair investimentos. Era um argumento que falava ao bolso dos políticos nacionais. (BARBOSA, 1912, v. 39, t. 1, p. 220)

Nada disso impediu Seabra de assumir o governo do Estado, em 28 de março de 1912. O novo governador, até então, mantivera-se fora da Bahia, sem participar diretamente dos eventos. De fato, na semana explosiva do bombardeio, Seabra apareceu placidamente em foto da revista Fon-fon, participando de uma cerimônia de casamento no Rio de

7 Uma consequência dessa história foi a "fúria" de homenagens ao barão do Rio Branco no período seabrista. Além da estátua na avenida Sete de Setembro, o barão foi homenageado com a colocação de seu nome no novo palácio do governo (Palácio Rio Branco) e na localidade que se chamava Santo Antônio do Urubu. O nome atual desse município, Paratinga, nada mais é do que a tradução de Rio Branco para o tupi, como aponta Cid Teixeira. (LINS, 1988, p. 44) 
Janeiro. Quando finalmente veio à Bahia, já foi como governador eleito. Os rituais de desembarque e recepção levaram uma enorme multidão às ruas, o que certamente dá o que pensar. Quem era esse povo que, depois de tantos tumultos e violências, ainda prestigiava o ex-ministro, a quem se atribuía a "autoria intelectual" do bombardeio?

Segundo Rui, o que os seabristas chamavam de "povo" não passava de uma "malta arruaceira", "patuleia de sicários", "escória das calçadas", "lixo de todos os motins", formada basicamente por soldados disfarçados e maus elementos, aos quais se juntaram funcionários de repartições federais, como os Correios e Telégrafos, e de empresas ligadas ao ministro da Viação, como a companhia das obras do porto e a casa Guinle. (BARBOSA, 1912, v. 39, t. 1, p. 219, 241, 355) Deixando-se de parte os termos pejorativos e elitistas, como malta, patuleia, escória e lixo, a acusação de Rui não era desprovida de sentido, pois militares, funcionários e empregados das companhias interessadas na ascensão de Seabra participaram, efetivamente, da multidão que legitimava as ações seabristas no período.

No tocante aos militares, vários oficiais envolvidos nos eventos de 1912 viriam a integrar, mais tarde, as hostes políticas de Seabra. O tenente Propício da Fontoura, sobrinho do novo ministro da Guerra (Mena Barreto) e o tenente Ferreira de Matos, comandante de scout Bahia, foram eleitos deputados federais pelo partido seabrista. O próprio general Sotero, responsável direto pelo bombardeio, elegeu-se senador estadual. Quanto aos funcionários e empregados das companhias, basta um exemplo: em 12 de dezembro de 1911, a Gazeta do Povo publicou uma extensa lista nominal de operários da Viação Baiana que apoiavam a candidatura Seabra. Sabendo-se que essa empresa ferroviária era dirigida por Miguel de Teive e Argolo, sogro do político seabrista Muniz Sodré, pode-se imaginar de que formas o apoio dos trabalhadores foi "estimulado" pelos patrões.

A multidão que se vê nas fotos da época, entretanto, não se limita aos soldados, funcionários e empregados das companhias interessadas na ascensão do seabrismo ao governo. Havia mais gente disposta a sair

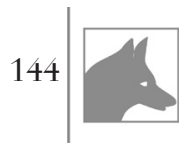


às ruas para prestigiar o novo governador. Como já se assinalou, Seabra tinha uma antiga ligação com setores do operariado da capital. Em setembro de 1911, ele foi agraciado com o diploma de sócio benemérito do Centro Operário da Bahia. Dois meses depois, essa entidade lançou a candidatura de Mário Hermes à Câmara Federal. (GAZETA DO POVO, 27 nov. 1911) Há tempos, dizia-se que essa candidatura era a raiz do grande prestígio de Seabra junto ao presidente, e agora os operários baianos tomavam a "iniciativa” de cumprir a promessa. É provável, pois, que muitos trabalhadores ligados ao Centro Operário tenham participado dos rituais públicos pró-Seabra. Além disso, o time de meetingueiros do seabrismo (Rafael Pinheiro, Ângelo Dourado, Cosme de Farias, entre outros) estava nas ruas, mobilizando a população urbana a favor do seu chefe.

Outros elementos de maior poder econômico também apoiavam o seabrismo ascendente. A Associação Comercial da Bahia, por exemplo, participou ativamente das negociações para a solução da crise política. A entidade sempre esteve muito próxima aos donos do poder político da Bahia, embora mantivesse uma fachada de neutralidade. Representava os interesses do alto comércio e mantinha uma constante pressão sobre os governantes pela redução de impostos e pela manutenção da ordem. Seu presidente, Antônio Soveral, fez parte da comissão que foi buscar a primeira renúncia de Aurélio Viana, e apoiou a ascensão de Bráulio Xavier ao governo. (GAZETA DO POVO, 13 jan. 1912) Desde a visita do marechal Hermes, em julho de 1911, quando a Associação foi presenteada com uma faixa de terra e com a reforma de parte do cais do porto, a entidade vinha se alinhando ao ministro Seabra. Abandonando sua tradicional prudência, as "classes conservadoras" embarcavam alegremente na caravana seabrista, que prometia trazer o progresso e o desenvolvimento para a velha Bahia.

Além dos trabalhadores e comerciantes, é preciso não esquecer que muitos políticos tradicionais já haviam aderido ao seabrismo. As demonstrações incontestáveis de força durante todo o ano de 1911 
e os primeiros meses de 1912, com a prova inequívoca do bombardeio, convenceram até os chefes mais cautelosos de que a maré havia virado definitivamente para o lado de Seabra. Os seabristas de última hora precisavam demonstrar publicamente sua adesão, o que se fazia de duas maneiras: através de votos e da presença nos rituais, com seus subordinados e agregados. Com isso, levava-se mais água ao moinho seabrista.

O episódio do bombardeio, com seus desdobramentos, assinalou o primeiro grande confronto entre Rui Barbosa e J. J. Seabra. A força do verbo de Rui não foi capaz de deter a capacidade de articulação de Seabra, que finalmente concretizou seus planos de tomar o controle da política baiana. $O$ fato de que isso tenha ocorrido pela força dos canhões não invalida a avaliação feita, no ano anterior, pelo filho de Rui, de que Seabra preferia alcançar seus objetivos "pelos meios naturais". Ocorre que, no contexto do governo Hermes, a associação com os militares salvacionistas era o opção mais atraente para dobrar a resistência combinada dos adversários marcelinistas, severinistas, ruístas e pinheiristas.

Em retaliação às ações de Rui Barbosa no plano nacional, e aos ataques verbais ao seu chefe, os seabristas chamaram o senador de "velhote desorientado", "chefe nato de todas as revoluções e rebeliões que tem havido no Brasil", "figura tétrica”, "esquálida", "demente", "grande gênio da destruição que nada jamais construiu nem construirá”, "duende”, entre diversos outros. Rui era apresentado como filho ingrato da Bahia, que só sabia destruir, além de velho e fisicamente frágil. Era o contraponto exato à imagem que Seabra vinha tentando construir para si mesmo. Alto, corpulento, com seus bigodes pintados de preto, o novo governador buscava aparentar juventude, força, virilidade, além de capacidade administrativa e apego extremado à terra natal. $\mathrm{O}$ discurso da baianidade e do político realizador, tocador de obras, tão acionado na Bahia ao longo do século XX, teve sua gênese com Seabra.

O texto a seguir, publicado na Gazeta do Povo (27 mar. 1912), é exemplar da versão seabrista desse momento. Observe-se a estrutu-

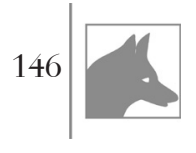


ra das rimas, o sabor distintamente popular e épico dos versos, que se assemelham a literatura de cordel, o recurso a imagens religiosas (se Rui recorreu ao Supremo Tribunal Federal, Deus, em seu Tribunal Supremo, intercede a favor dos seabristas) e a visão de Seabra como um guia iluminado que conduz o povo para o futuro. Palinuro era o piloto do navio de Eneias, na Eneida da Virgílio, e Josué liderou os hebreus na conquista da terra prometida. A referência ao visconde do Rio Branco (Paranhos) é mais uma homenagem ao seu filho, o barão. O bobo no palácio das Mercês é, evidentemente, o governador Araújo Pinho.

\section{À Bahia Livre}

Reinava aqui na Bahia
A bacanal mais vilã
$\mathrm{O}$ governo era uma orgia

Onde imperava o can-can!

Foi uma quadra medonha

Por toda parte a vergonha

A todo instante o dobrez

E p'ra cúmulo do deboche

Deixaram um bobo, um fantoche

No palácio das Mercês... [...]

Afinal, em santo alarde

Triunfou a Revolução!

Todo bandido é covarde,

Como é covarde o ladrão...

Por isso, cheios de medo,

Fazendo d'honra um brinquedo

Os réus fugiram de nós 
Longe daqui, tendo em mira Sempre a traição e a mentira Foram cuspir nos Heróis.

Mas Deus, que nos viu na liça

Lutando, heróicos, de pé

Pela lei, pela justiça,

Pela Pátria e pela Fé...

Deus, no Tribunal Supremo,

Tomado do zelo extremo,

Foi o nosso defensor...

Vencemos! Eis a vitória!

Cantemos hinos de glória

Ao grande Libertador.

Bahia! Terra sagrada,

De Paranhos genetriz...

Nas águas lustrais banhada,

Levanta agora a cerviz!

Eis aqui, teu povo inteiro,

Remido do cativeiro,

Caminha, cheia de fé...

Para salvar o futuro,

Deus nos deu um Palinuro...

Ressuscitou Josué!... 
Figura 5. Comício no Largo de São Francisco, em meio à crise do bombardeio

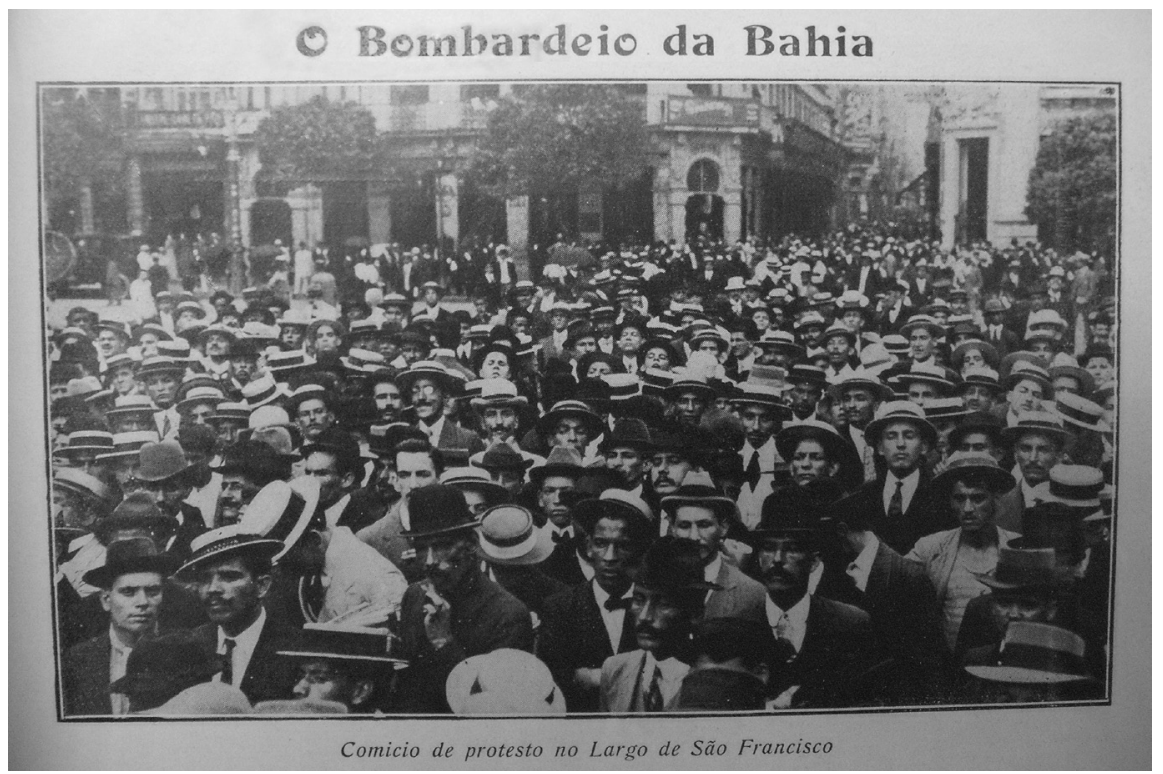

Fonte: Careta, 20/01/1912

Figura 6. Confronto entre manifestantes e policiais

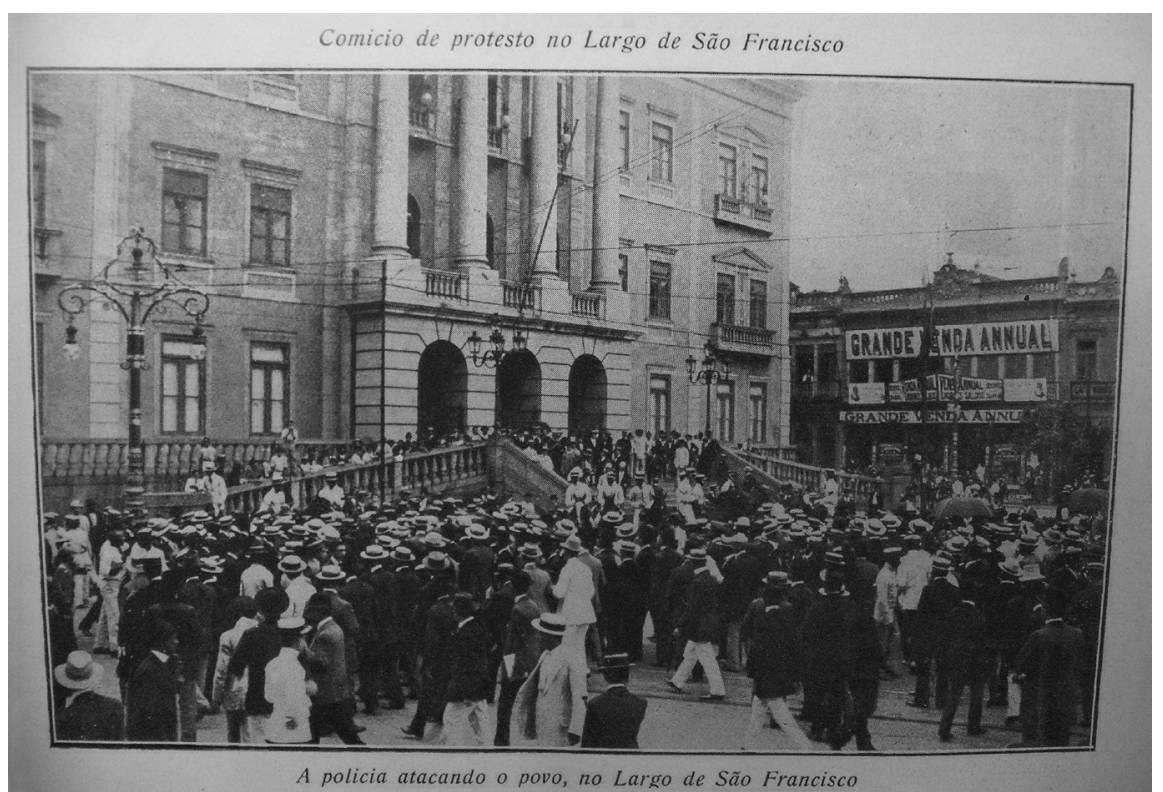

Fonte: Careta, 20/01/1912

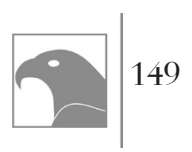


Figura 7. Embarque de militares no Rio de Janeiro para a Bahia

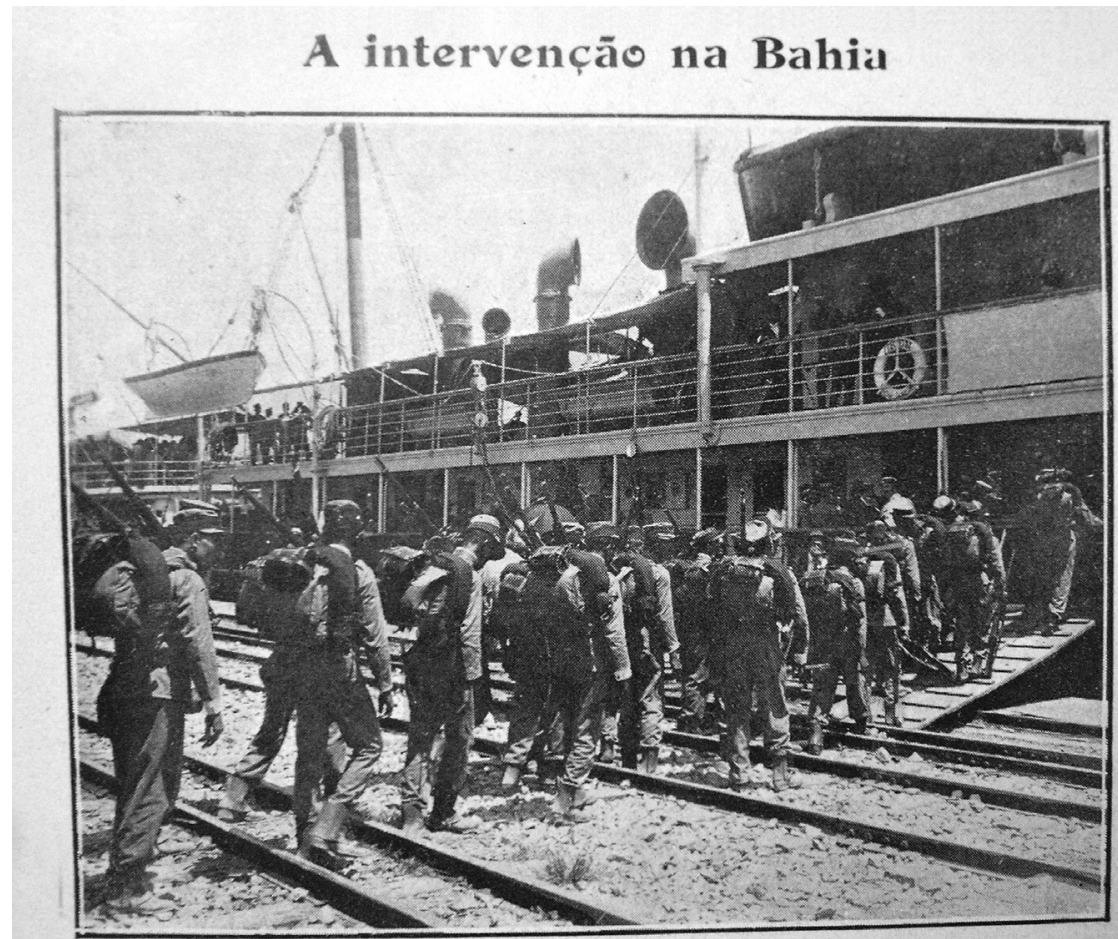

Embarque do 53 de caçadores, em nosso porto

Fonte: Careta, 03/02/1912

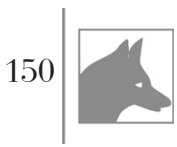


Figura 8. Seabra abraça o coronel Sotero no retorno ao Rio

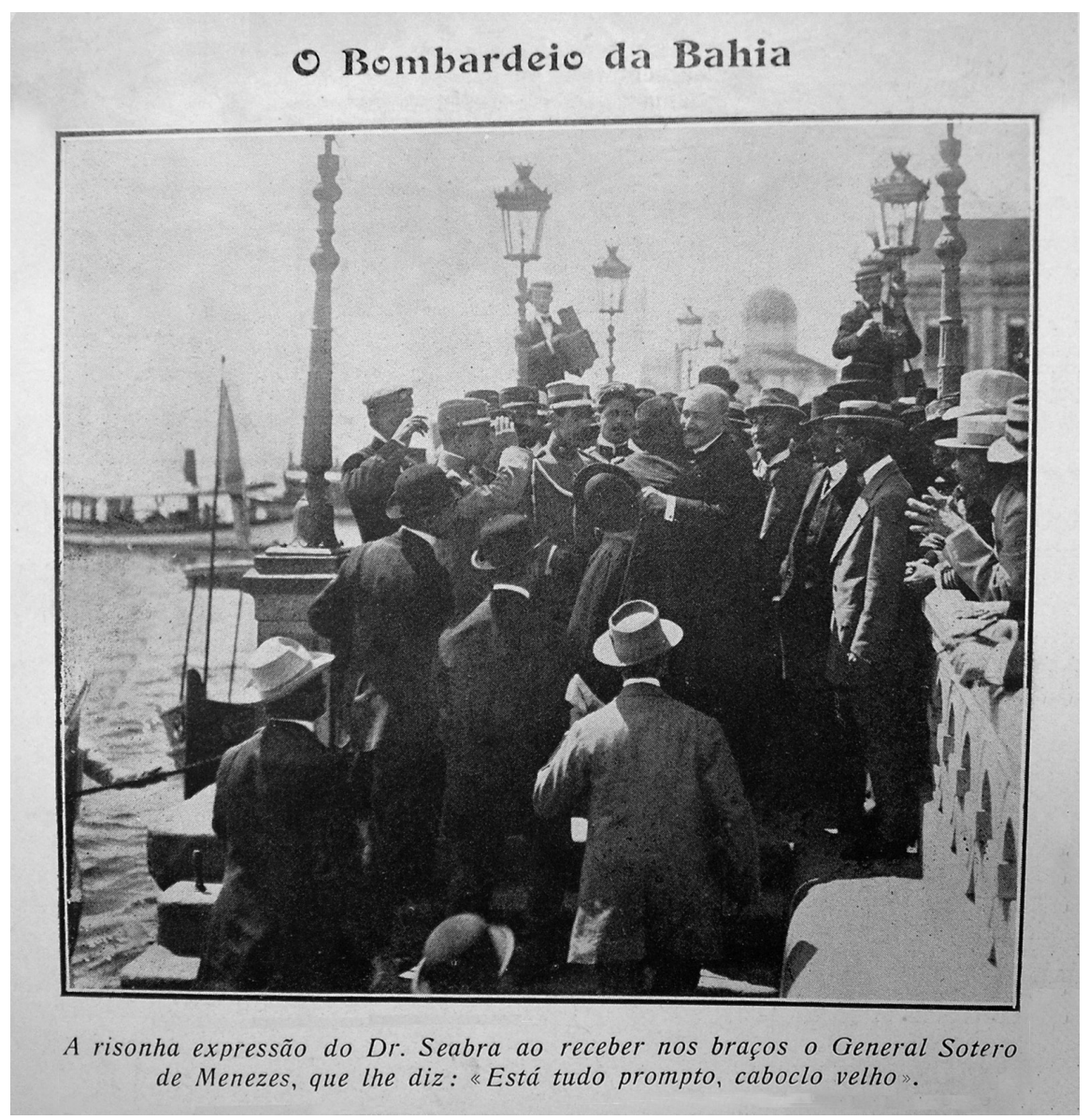

Fonte: Careta, 10/02/1912 
Figura 9. As eleições na Bahia

\section{As eleições na Bahia}

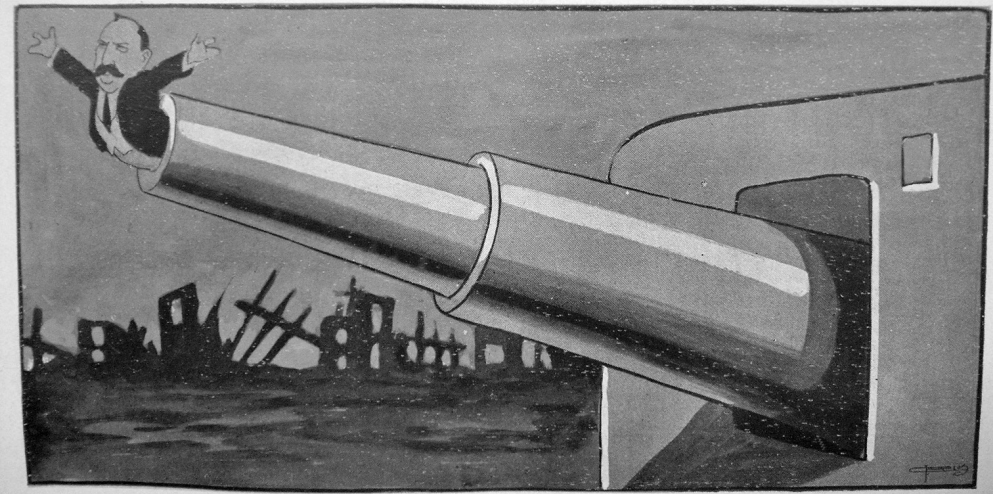

H upna e o candidato eleito

Fonte: Careta, 10/02/1912

Figura 10. Vox Populi - Vox Dei

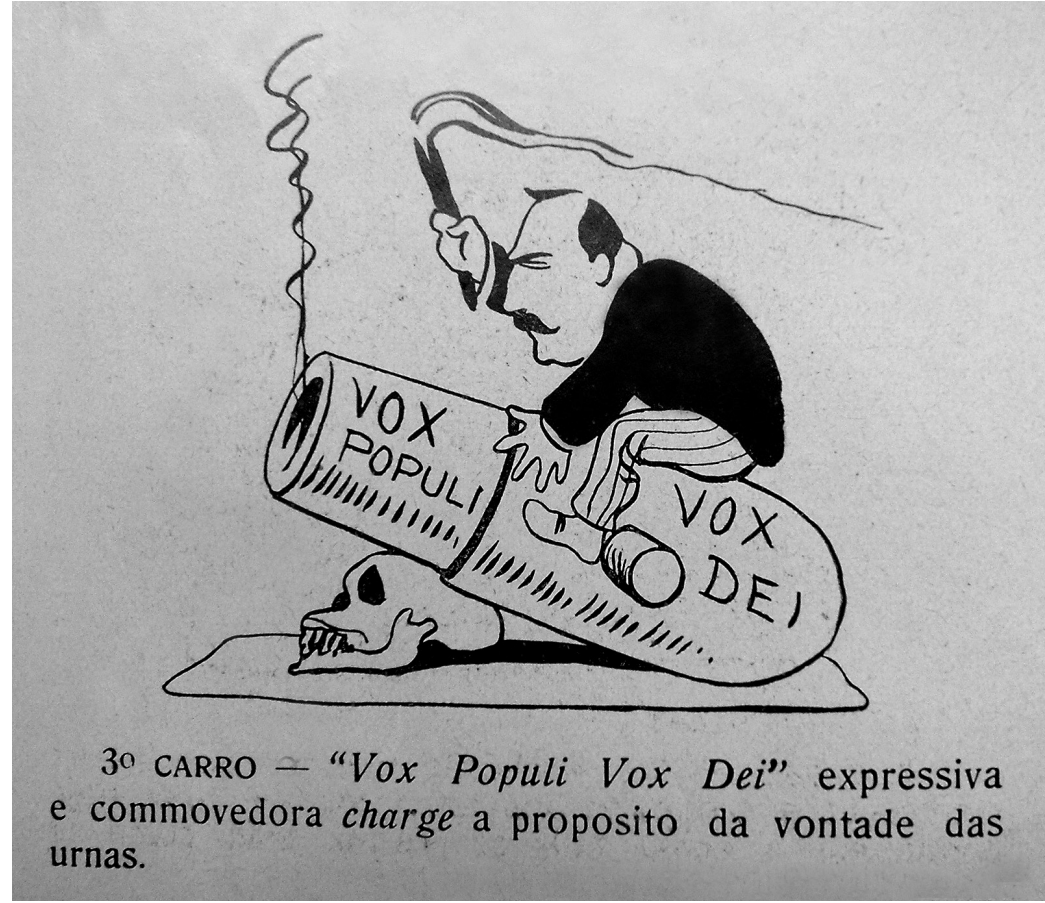

Fonte: Careta, 06/04/1912

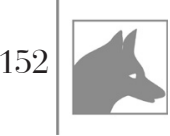


Figura 11. Na Bahia, os milagres de São Marcelo

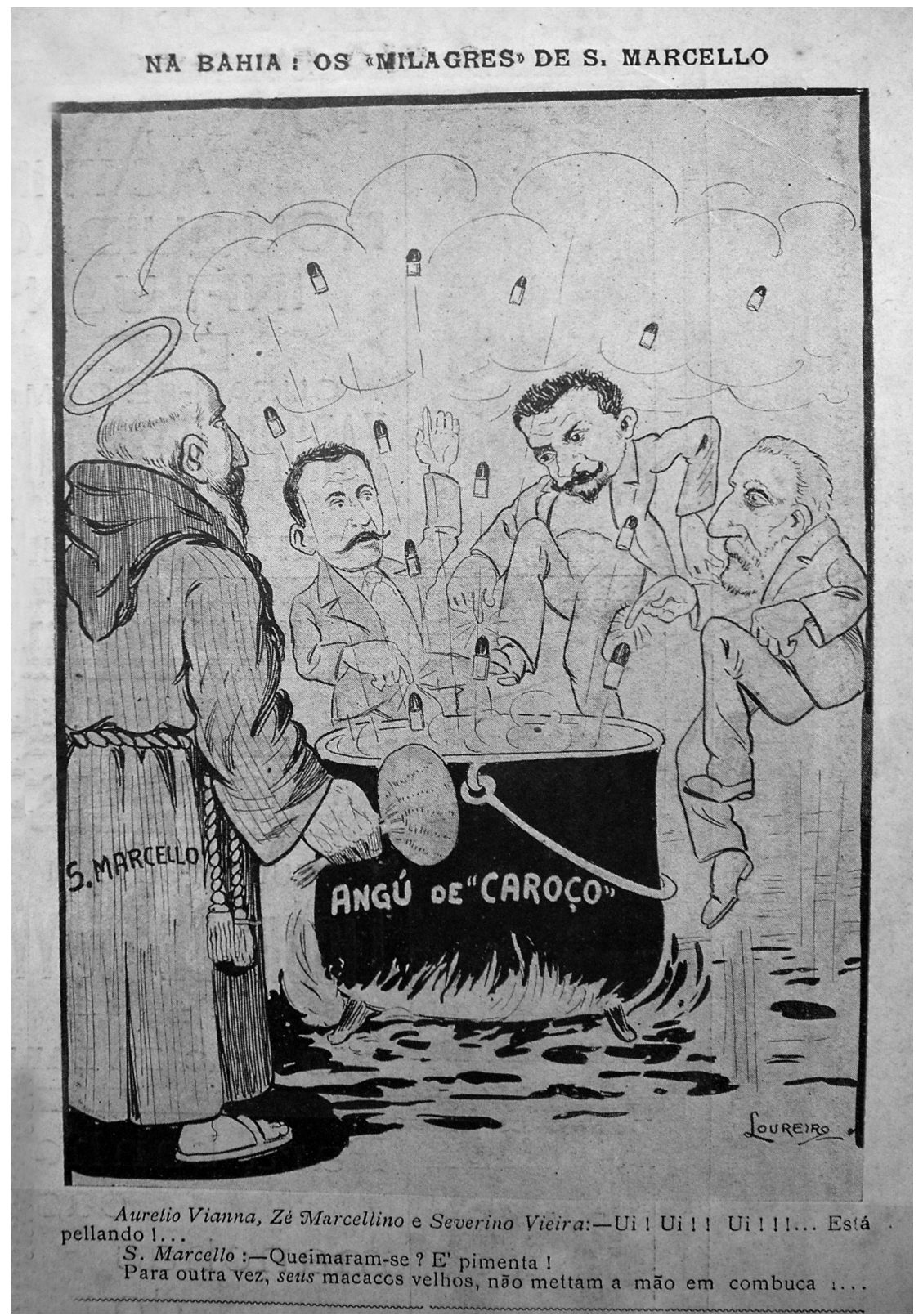

Fonte: 0 Malho, 20/01/1912 
Figura 12. Sobre o tal bombardeio da Bahia

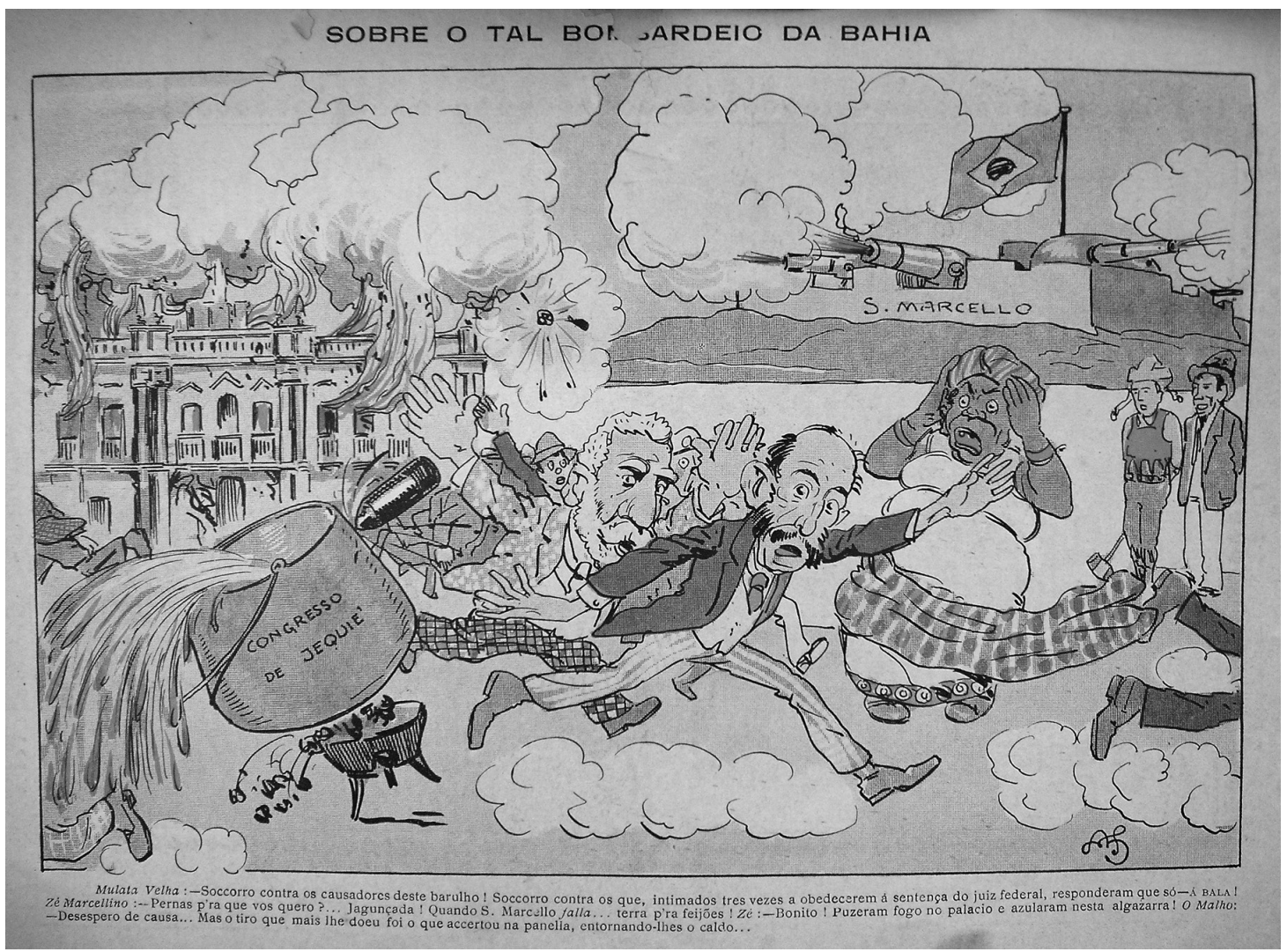

Fonte: 0 Malho, 20/01/1912

${ }_{15+}^{11}$ 
Figura 13. Metereologia política

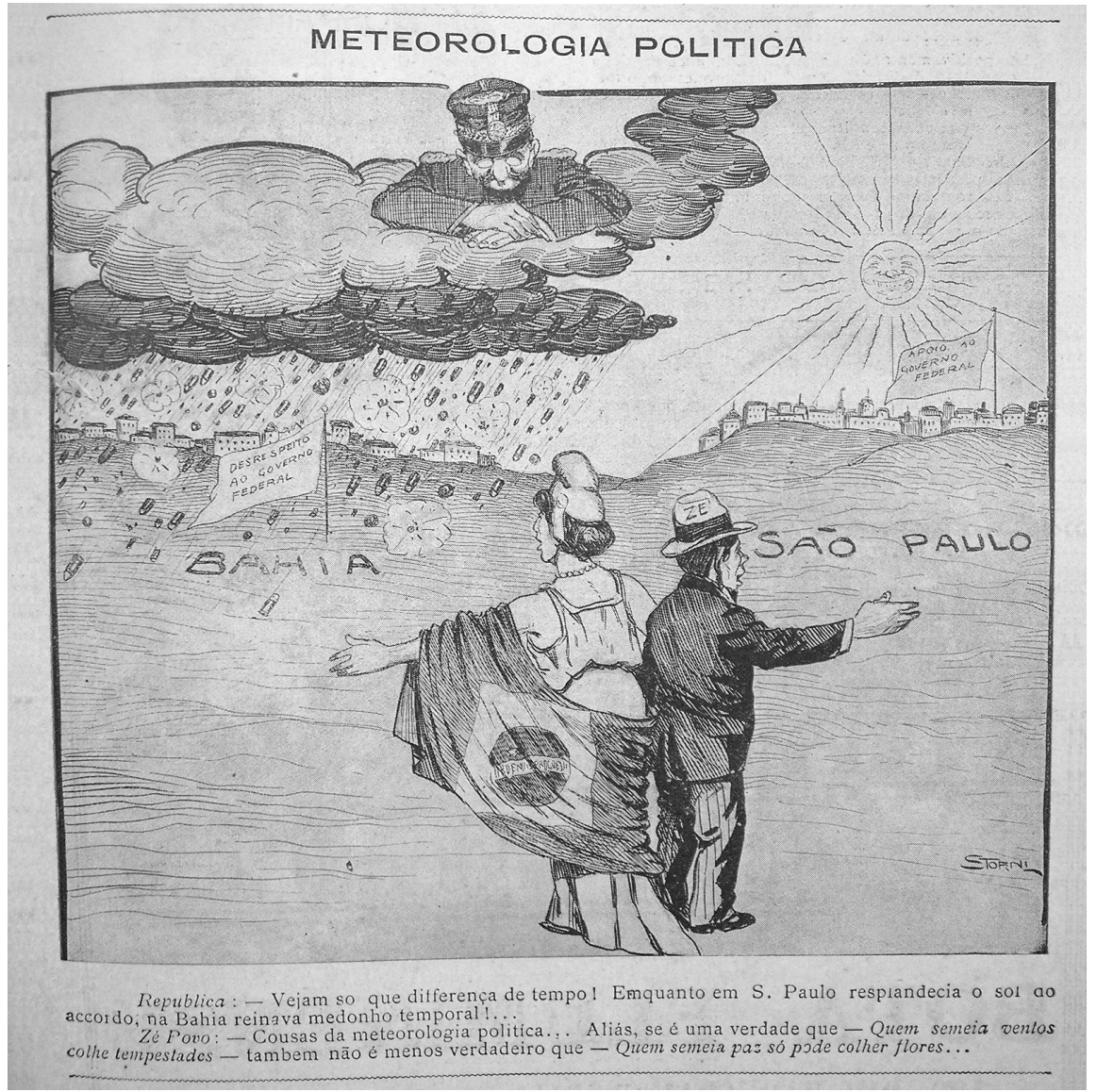

Fonte: 0 Malho, 20/01/1912 
Figura 14. No frigir dos ovos

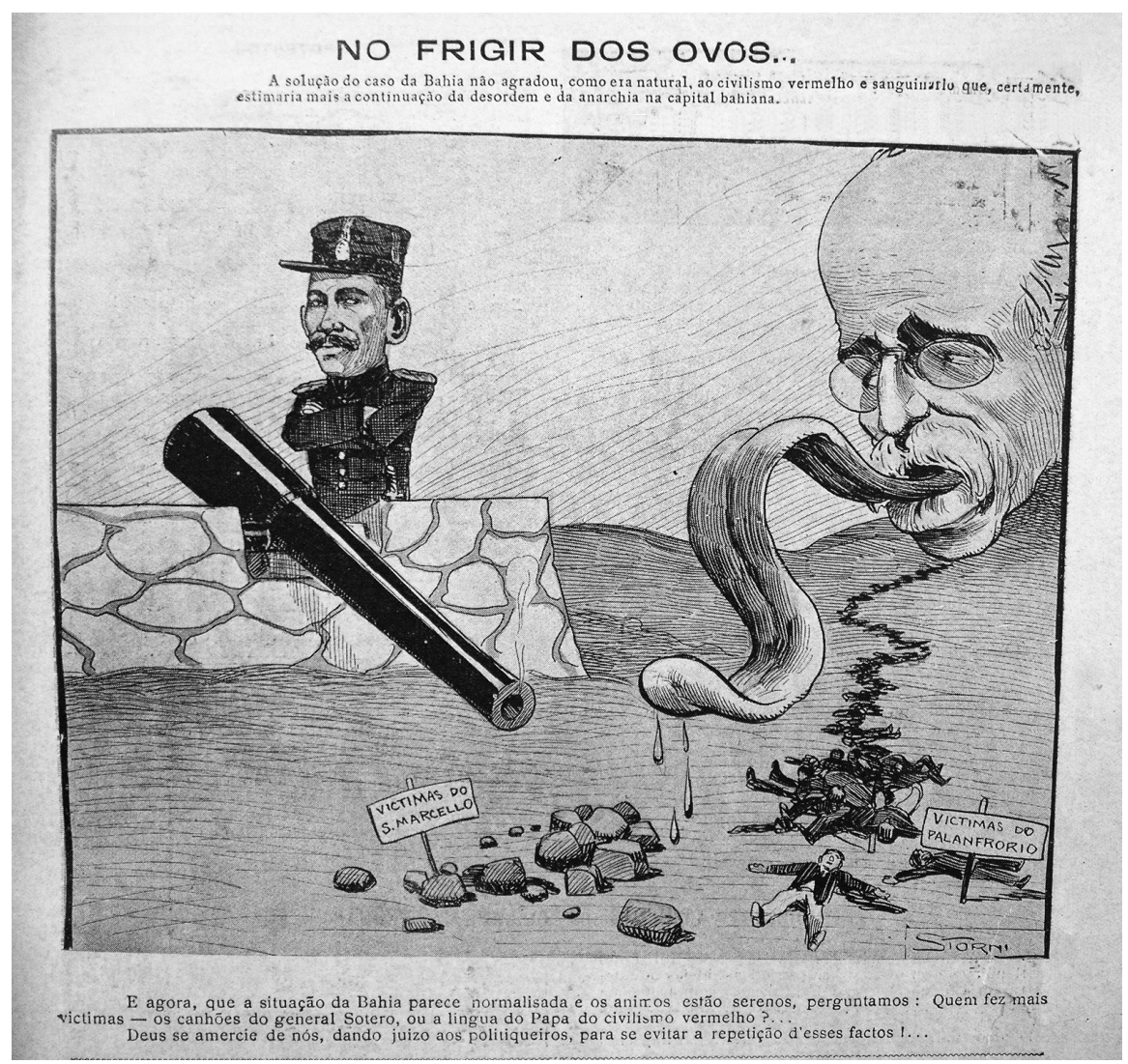

Fonte: O Malho, 17/02/1912 
Figura 15. Um quadro do "temporal" baiano

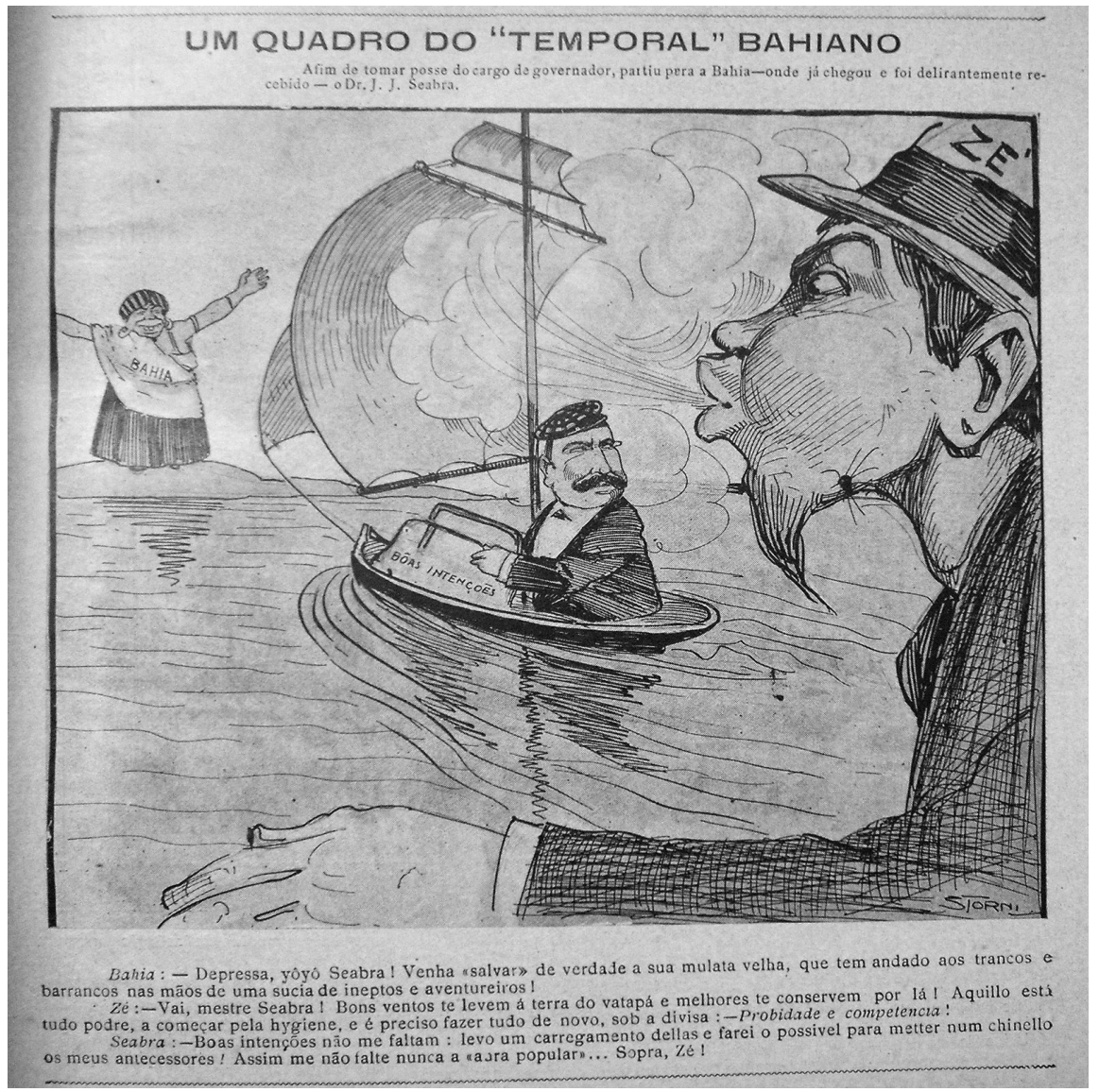

Fonte: O Malho, 30/03/1912 
Figura 16. Depois da moléstia

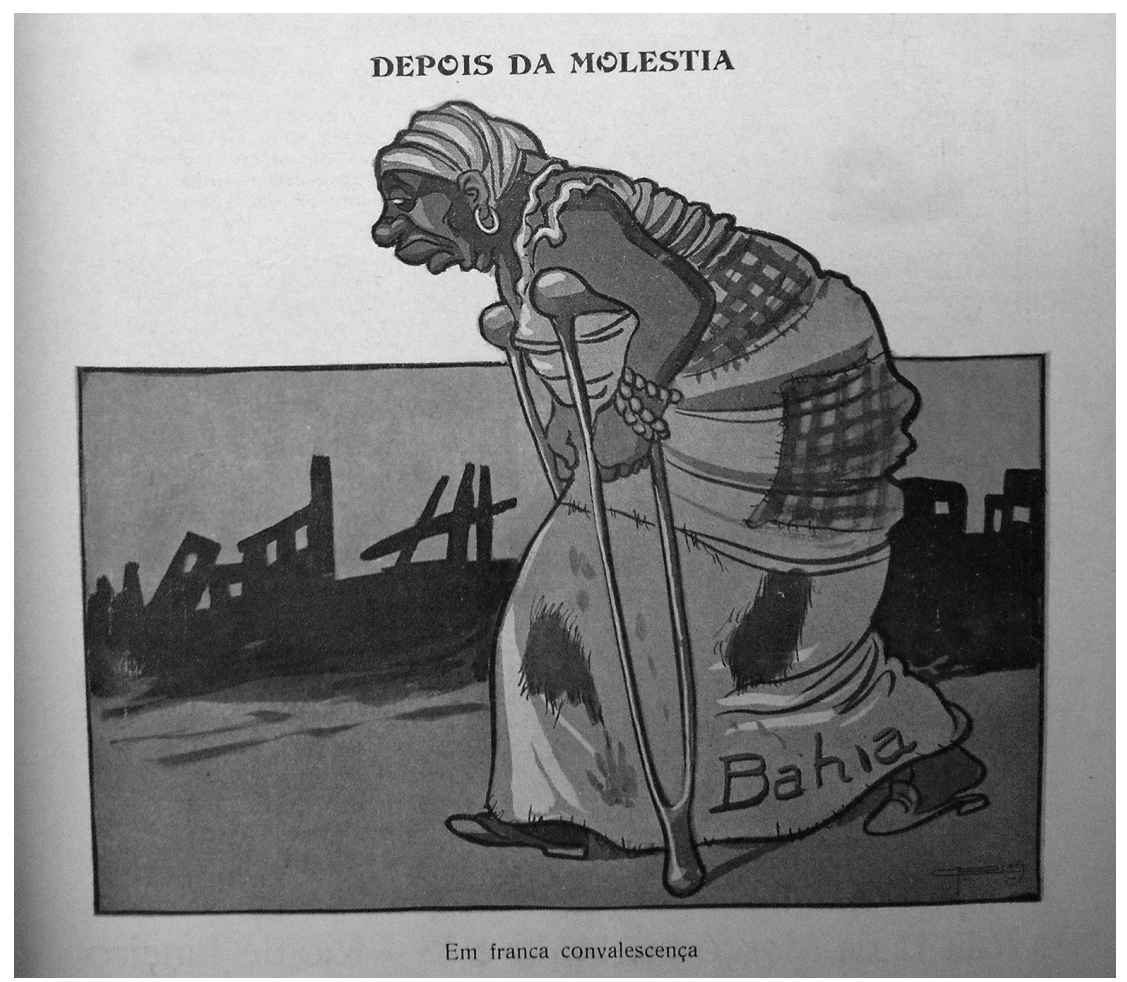

Fonte: Careta, 09/03/1912

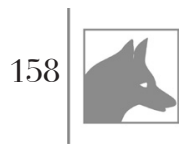




\section{Trégua e tensão (1913-1918)}

Apenas um ano e meio depois do bombardeio de Salvador, "Caim" e o "velhote desorientado" já faziam parte do passado, pois Seabra e Rui firmaram uma surpreendente aliança. $\mathrm{O}$ motivo da reaproximação foi o rompimento entre o governador baiano e o marechal Hermes, derivado do crescimento da influência de Pinheiro Machado sobre o presidente. Seabra continuava amigo de Mário Hermes, que era o líder da bancada baiana na Câmara Federal, mas o prestígio do grupo familiar decresceu após a morte da primeira esposa do marechal e seu rápido casamento com a jovem Nair de Tefé, mulher avançada para a época, o que não foi bem aceito pelos filhos. $\mathrm{O}$ drama familiar, somado à dispersão dos militares salvacionistas pelos respectivos estados, contribuiu para o recrudescimento da força de Pinheiro Machado, que tratou de afastar os que vinham tentando minar seu prestígio no governo federal, inclusive Seabra.

Em julho de 1913, pois, lá estava o governador Seabra, chefe do Partido Democrata, lançando a única candidatura que parecia capaz de combater a força de Pinheiro na sucessão presidencial: a do "grande cidadão Rui Barbosa", "egrégio brasileiro", "respeitado e prestigioso". (GAZETA DO POVO, 08 jul. 1913) A população de Salvador assistiu, então, surpresa, a passeatas acadêmicas, festas e meetings dos seabristas a favor de Rui. Cosme de Farias, como delegado da Liga Popular Rui Barbosa, saiu às ruas em propaganda da "gloriosa Águia de Haia" (GAZETA DO POVO, 16 jul., 5 ago. 1913). O jornal seabrista, antes tão hostil a Rui, derramava-se em elogios:

Não sabemos o que admirar mais no maior dos brasileiros, se o seu excepcional talento, se o seu raro e singular cultivo, ou se a grandeza, se o denodo, se o civismo incomparável com que se bate e com que se destaca, no nosso meio e na nossa época, como o apóstolo de todas as causas santas da liberdade. (GAZETA DO POVO, 05 nov. 1913) 
A essa altura, o instável tabuleiro da política baiana já tinha sofrido novas rearrumações, com várias peças trocando de lado. Luís Viana, eleito senador com apoio de Seabra, rompeu com o governador em janeiro de 1913. Na oposição, aliou-se ao antigo desafeto Severino Vieira, ambos sob a regência de Pinheiro Machado. Durante a campanha presidencial, José Marcelino ainda se manteve atrelado a Rui, mas, em 1914, ele também aderiu ao pinheirismo. Tão surpreendente quanto ver Seabra e Rui de mãos dadas era assistir à aliança dos três ex-governadores, outrora encarniçados inimigos, para combater o novo todo-poderoso da Bahia. (SAMPAIO, 1998, p. 127)

O nome de Rui não logrou obter apoio nacional para ser lançado à presidência, mas tampouco Pinheiro Machado conseguiu se colocar como sucessor do marechal. Ao fim das negociações, o vice-presidente da República, o mineiro Venceslau Brás, foi escolhido como nome de conciliação. Publicamente, os seabristas relutaram em abandonar Rui. O deputado Mário Hermes, em nome da bancada, declarou que a candidatura baiana fora apresentada antes da mineira, e que a Bahia continuaria com ela, mesmo sem a companhia dos demais estados. De fato, o governo baiano sustentou o nome de Rui mesmo depois da desistência do próprio candidato, em dezembro de 1913. A Gazeta do Porvo (22 fev. 1914) deu a palavra de ordem: "Rui ou ninguém!”.

Ainda que tudo isso tenha sido apenas um jogo de cena de Seabra, enquanto tentava se articular com a candidatura vitoriosa de Venceslau Brás, é fato que houve uma reaproximação dos dois baianos, que se converteu em aliança estratégica. A correspondência pessoal, interrompida em 1905, foi retomada. Em 1913, os dois filhos de Rui (Alfredo e João) estavam integrados à chapa oficial de candidatos do Partido Democrata, que incluía também amigos próximos do senador, como José Joaquim da Palma e José Maria Tourinho. Como consequência dessa aproximação, são raras as referências a Seabra ou ao bombardeio da Bahia nos discursos e artigos das Obras Completas de Rui Barbosa em 1913 e 1914. 
Nos discursos que fez sobre o recente bombardeio de Manaus, Rui praticamente não mencionou os fatos semelhantes ocorridos em Salvador no ano anterior, a não ser em breves referências. Da mesma forma, nas conferências que preparou para sua campanha presidencial de 1914, nunca proferidas, mas publicadas nos jornais, Rui usou termos enfáticos para lembrar as tragédias do Satélite e da Ilha das Cobras, mas falou genericamente sobre a intervenção nos estados. (BARBOSA, 1913, v. 40, t. 4; t. 5) Diante dos comentários sobre sua reconciliação com alguns salvadores do início do governo Hermes (além de Seabra, Nilo Peçanha, Dantas Barreto e Mena Barreto haviam se aproximado de Rui), o senador baiano alegou que todos tinham direito de reconhecer o erro e mudar de posição, e que foram os salvadores que mudaram, não ele. Quanto ao caso baiano, especificamente, observou:

$\mathrm{Na}$ Bahia, ninguém ignora a desabrida oposição por mim feita à política pela qual se estabeleceu naquele estado o governo de hoje. Sucedeu, porém, que o governo atual e o seu partido deliberaram levantar a minha candidatura à presidência quando esta candidatura estava mais do que definida como a candidatura do que chamavam Chefe do Civilismo [...] Como é do meu costume, [...] respondi agradecendo, mas lembrando que eu não era o indivíduo, eu era a expressão de um conjunto de idéias [...] A resposta que me deram da Bahia o governador e os membros do seu partido foi que me recebiam com minhas idéias, com o meu programa, com a minha bandeira. (BARBOSA, 1914, v. 41, t. 2, p. 289-290)

As fontes consultadas não revelam as opiniões de Rui sobre as ações desenvolvidas no primeiro governo Seabra, como a reorganização administrativa do Estado e a reforma urbana de Salvador, hoje questionada pelas demolições e pelo espírito de controle e higiene social que a orientava ${ }^{8}$.

8 Não se tratará aqui da reforma urbana seabrista, tema já abordado por diversos autores. Eloísa Petti Pinheiro (2002) relacionou a reforma baiana aos principais modelos da época: Paris (modelo mundial) e Rio de Janeiro (referência brasileira). Vale lembrar que Seabra, como ministro, participou da reforma do Rio. Alberto Heráclito Ferreira Filho (1998/1999) abordou a reforma seabrista, como também a posterior de Góes Calmon, em seu aspecto disciplinador e "desafricanizador" do ambiente urbano. Peres (2009) abordou 
Como a maioria dos contemporâneos de sua posição social, Rui compartilhava com Seabra do desejo de aproximar a Bahia e o Brasil dos modelos civilizacionais europeus, que eram o padrão ocidental. ${ }^{9}$ Ainda em 1893, em visita a Salvador, o senador lamentou o "aspecto colonial desta cidade, entrevada cinquenta anos na imobilidade dos seus bairros primitivos". Para ele, como para Seabra, a arquitetura colonial era símbolo do "atraso" da Bahia. As fontes consultadas não registram campanha de Rui contra as ações da "picareta civilizadora", mesmo tendo recebido da sobrinha Amália Lopes Barbosa um apelo para que lutasse contra a demolição do mosteiro de São Bento, que estava no caminho da nova avenida projetada por Seabra, depois denominada Avenida Sete de Setembro. Ao que parece, Rui não se engajou na questão. $\mathrm{O}$ mosteiro permaneceu de pé graças à persistência do seu abade. (FCRB/ARB/CRUPF 827/1 30/08/1912)

Em 1914, Seabra convocou Rui para uma surpreendente missão: representar o município de Salvador em uma questão contra a empresa Guinle E Cia, que estava devendo certa soma aos cofres municipais, proveniente de um empréstimo externo, do qual Eduardo Guinle serviu como intermediário. Em razão dessa dívida, o intendente Júlio Brandão, antigo gerente da Circular, solicitara à Justiça que declarasse a falência dos ex-patrões. Os Guinle, por sua vez, alegavam que o montante devido era menor do que o valor cobrado pelo município e questionavam a honestidade de Júlio Brandão, acusando o intendente de ter "abocanhado" uma "grossa fatia" da verba destinada aos melhoramentos da cidade. (GUINLE \& C., 1914, p. 13) Um dos advogados dos Guinle era Aurelino Leal, político severinista.

a questão da destruição do patrimônio colonial. É interessante observar que a reforma seabrista, apesar de seu impacto físico e simbólico, ficou muito aquém das intenções iniciais. A Primeira Guerra Mundial, e a drástica redução de capital disponível para investimentos nos países periféricos dela decorrente, reduziram sua abrangência.

9 Segundo Norbert Elias (1994, p. 23), o conceito de civilização expressa a "consciência que o Ocidente tem de si mesmo". O autor analisou o processo civilizador como transformador do comportamento humano nos países centrais, com a introdução de normas de higiene e disciplina corporal/social. As sociedades periféricas, como a brasileira, tentavam se adequar a esses padrões. Para uma visão dessas questões na Bahia da época, ver o trabalho de Rinaldo Leite (1996). 
Trata-se de um episódio complexo, que merece aprofundamento em pesquisas posteriores. À primeira vista, parece que Seabra havia rompido com os Guinle, seus aliados de longa data. Isso explicaria, não somente sua atitude de contratar Rui Barbosa, como o fato de os Guinle terem adotado um adversário do seabrismo como advogado. Mas, as coisas podem ser diferentes do que aparentam, pois Seabra também estava rompido com Júlio Brandão, e dizia que o dinheiro restituído não deveria ir para as mãos do intendente, pois os credores corriam o risco de serem "flauteados", isto é, lesados. Estaria ele, então, protegendo os interesses dos Guinle, enquanto publicamente os combatia? (GAZETA DO POVo, 12 dez. 1914)

A questão fica ainda mais intrincada quando se sabe que Seabra, através do Conselho Municipal, mandou aprovar um prêmio de cem contos de réis a Rui, por sua atuação no caso. Segundo ele, não se tratava propriamente de um pagamento, pois os serviços de Rui eram "inestimáveis", mas apenas de "uma lembrança pelo grande triunfo alcançado [em] favor [dos] interesses [do] município". No acervo de Rui, entretanto, há também uma carta do próprio Júlio Brandão, em dezembro de 1914, agradecendo pelo apoio e pedindo: "não me desampare em momento tão angustioso, vítima que sou da paixão dos homens e da perseguição dos poderosos". (FCRB/ ARB/CRUPF 1332-1/1 14/09/1914; ARB/CRUPF 229 05/12/1914) A solicitação de Júlio Brandão deve ter sido atendida, pois ele acabou se tornando amigo de Rui e, anos depois, seu sócio em uma fábrica de soda cáustica chamada Carbônica. São, em suma, negócios muito complicados dos bastidores da política, que merecem novas investigações.

Em janeiro de 1915, tudo parecia tranquilo entre Rui e Seabra, ao menos na superfície. O partido seabrista renovou o mandato de Rui no Senado. Por telegrama, Seabra informou a Rui que seu "prestigioso e aureolado nome [...] foi justa, brilhante e patrioticamente sufragado" com 85 mil votos. $O$ governador tentava claramente agradar o senador. No acervo de Rui, resta ainda hoje o cartãozinho que acompanhou uma 
caixa de mangas de Itaparica, mandadas por Seabra exatamente nessa época. (FCRB/ARB/CRUPF 1332-1/1 24/02/1915) Rui também defendeu o grupo seabrista dos ataques da oposição baiana, representada pelos partidários unidos de Luís Viana, José Marcelino e Severino Vieira, que tinham promovido uma "duplicata" na Câmara estadual. Em maio, contando com a força de Pinheiro Machado, a oposição forçou uma redistribuição das vagas baianas no Congresso, "degolando" candidatos do governo estadual. Graças à ação de Rui, as sete vagas concedidas inicialmente por Pinheiro Machado transformaram-se em quatorze, que ele e Seabra tiveram que dividir entre seus respectivos "amigos". (SAMPAIO, 1998, p. 128; BARBOSA, 1915, v. 42, t. 2, p. 249-255)

Apesar dessa reaproximação, a tensão latente entre Rui e Seabra não demoraria a vir à tona. Ambos tinham vocação para chefiar, e não serem chefiados, e só havia espaço para um cacique na política baiana. Até 1915, a habilidade política de Seabra à frente do governo estadual e a existência de um poderoso inimigo comum (Pinheiro Machado) mantiveram a aliança incólume. A partir desse ano, contudo, os problemas começaram a emergir.

O sistema eleitoral da Bahia na Primeira República era coalhado de vícios que favoreciam o continuísmo no poder, mas não permitia a reeleição sucessiva do governador. Por isso, ao se aproximar o fim do seu período governamental, Seabra se deparou com o problema de escolher o sucessor. Ele não pretendia repetir a moda dos governadores anteriores e ter uma passagem efêmera pelo poder estadual. Para estabelecer um mando duradouro, precisava nomear alguém genuinamente seabrista, incapaz de uma traição. Foi a propósito dessa difícil escolha que se deu a primeira fissura na aliança. Rui, evidentemente, queria indicar alguém mais próximo ao seu grupo. Os elementos hostis a Seabra aguardavam sua posição. Na Bahia, disse o deputado Lemos Brito a Alfredo Rui, todos "esperam ansiosos a indicação do candidato pelo Velho". O missivista comentou que essa era a oportunidade "para vocês experimentarem

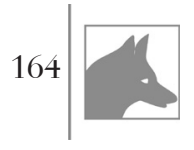


a sinceridade do Seabra”, e fez um apelo: "Salvem a Bahia!". (FCRB/ARB/ CRUPF 244 08/08/1915)

As articulações para a sucessão governamental foram extensas e complicadas. Rui, inicialmente, sugeriu seu amigo José Joaquim da Palma, mas Seabra alegou que esse nome não era aceito pelo partido. Depois, Seabra propôs a candidatura do juiz Paulo Fontes, mas a retirou assim que Rui a aceitou, alegando que, novamente, o partido não concordava. Em meio às negociações, Seabra parece ter contado com a boa vontade de Alfredo Rui, com quem já se relacionava em termos de amizade. Como Mário Hermes, Alfredo Rui também se deixou encantar pelas artes políticas de Seabra, que dizia querer resolver tudo de acordo com seu pai, com quem declarava ter uma "aliança até a morte". Há indícios de que Seabra tenha, inclusive, dado a entender que o próprio Alfredo Rui poderia ser o candidato. $\mathrm{Na}$ Bahia, porém, os políticos mais bem informados sabiam que Seabra tentava, a todo custo, impor o nome do deputado federal Antônio Muniz, que encontrava resistências junto aos ruístas e também entre alguns seabristas.

Nos arquivos consultados, há muitas referências a grupos que desejavam manter a união Rui-Seabra e de outros que queriam rompê-la. Aparentemente, Seabra se esforçava para manter a aliança com Rui e usava todos os artifícios disponíveis para isso, exceto recuar da indicação do seu candidato preferido. Um interessante testemunho dessa atitude é o depoimento de Joaquim Pereira Teixeira, que serviu de emissário de Rui junto a Seabra. Em carta ao senador, ele contou que chegou a Salvador ainda de madrugada e seguiu para o palácio do governo, onde encontrou Seabra ainda de pijamas. De lágrimas nos olhos, o governador o recebeu perguntando: "Então, meu filho, V. vem fazer minha deposição?”. Surpreso, Pereira Teixeira explicou que vinha em missão de paz, mas Seabra lhe deu um envelope, dizendo que continha sua renúncia ao governo. Pediu que entregasse o documento a Rui como prova de sua estima e solidariedade. Pereira Teixeira, em seu relato posterior, comentou 
Devo, a bem da verdade, declarar nunca ter visto Seabra tão comovido. Mal podia falar. Já nas conferências anteriores, referiu-se ao Rui com lágrimas nos olhos e mostrando ressentimentos de que Rui não acreditasse na sincera solidariedade que com ele mantém.

No momento em que entregou a renúncia, disse apenas:

- Fique certo de que não brigarei mais com esse homem. (FCRB/ARB/ CRUPF 1447 26/08/1915)

Pereira Teixeira explicou a Seabra que não queria sua renúncia, mas pediu que ele adotasse uma solução conciliatória, ao que ele respondeu: "pergunte ao Rui se ele teria coragem de abandonar o Alfredo ou o Palma. Abandonar o Antônio Muniz, nesse momento, é traí-lo. Prefiro deixar o cargo e a política”. Na despedida, ainda deu uma razão emocional para sua escolha:

Antônio Muniz é como se fosse meu filho. Eu não estimo o Zeca e o Carlos [filhos de Seabra] como estimo a ele. O pai desse homem morreu pedindo unicamente isso, que me acompanhasse até o fim da vida. Não precisaria pedir, pois o filho nunca pensou em outra coisa. Esse homem foi o meu partido na Bahia. Não se registra dedicação política igual. Eu terei necessidade de deixar logo a Bahia e não voltar aqui para que ele possa administrar.

Diga, enfim, ao Rui, que é a mim que ele aceita como governador, não é ao Muniz. (FCRB/ARB/CRUPF 1447 26/08/1915)

A última frase resume a raiz da insistência de Seabra e das resistências de Rui. De fato, o que se discutia, no fundo, era a continuidade do mando seabrista. Seabra apelou até para a esposa de Rui para obter as boas graças do aliado para sua escolha ("Fale também a D. Cotinha em meu nome. Peça-lhe que intervenha e que solicite a Rui o que estou a implorar", disse ele a Pereira Teixeira no mesmo encontro), em vão. Quando o nome do candidato oficial foi divulgado, Rui reagiu

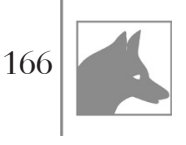


friamente. Em agosto de 1915, em uma reunião de deputados baianos em sua casa, o senador explicitou formalmente sua opinião. Lembrou os motivos de sua aliança com Seabra, as contribuições que deu ao partido governista baiano e as conversas sobre a sucessão, em que Seabra insistia que sua cooperação era fundamental. Concluiu dizendo que, como sua opinião não foi levada em conta, não se considerava responsável pela escolha. Sem romper ainda publicamente com Seabra, disse que o caso se resumiu a uma "questão doméstica”, em que os dirigentes do Partido Republicano Democrata já não acreditavam que valesse a pena "levar em conta o aliado cuja colaboração e solidariedade até há pouco reputavam essenciais". (BARBOSA, 1915, v. 42, t. 2, p. 249-255)

Novamente, as palavras de Rui revelam sua profunda irritação. Outros fatos ocorridos em 1915 contribuíram para deixar clara a estratégia seabrista de se manter no controle do poder estadual. A reforma da Constituição Estadual (24 de maio de 1915) e a lei de organização municipal (Lei 1.102, de 11 ago. de 1915) extinguiram a eleição para os intendentes municipais, que passaram a ser nomeados pelo governador. Dessa forma, Seabra tentava domar os chefes do interior, centralizando o poder em Salvador. Sua estratégia era simples: deixar os “coronéis" rivais lutarem entre si, para depois apoiar o vencedor. (SAMPAIO, 1998, p. 140)

Após a morte de Pinheiro Machado, em setembro de 1915, a aliança Rui-Seabra perdeu ainda mais o sentido. A falta de habilidade política de Antônio Muniz, que assumiu o governo baiano em 1916, também contribuiu para fragilizar os laços com os ruístas. Entre 1916 e 1917, Rui foi se afastando dos seabristas e se aproximando dos oposicionistas que, especialmente após a morte de José Marcelino (26 abr. 1917) e de Severino Vieira (23 set. 1917), vinham tentando atraí-lo para seu lado. Um dos marcos dessa aproximação foi um discurso que Rui proferiu em setembro de 1917, no Teatro Lírico, no Rio de Janeiro, com críticas aos governos de Seabra e de Antônio Muniz. Essa oração, segundo Consuelo Novais Sampaio (1998, p. 139), "despertou da letargia as facções opo- 
sicionistas do estado”. A partir de então, elas adotariam como estandarte, em sua guerra contra o seabrismo, a figura mítica da Águia de Haia.

Um exemplo do aproveitamento do perfil heroico de Rui para fins políticos foi a grande festa promovida em 1918, a pretexto do que se chamou Jubileu Cívico Literário de Rui Barbosa ou, simplesmente, as Festas do Solo sol, no caso, era metáfora para o brilho e a importância de Rui. Segundo Gonçalves (2000a, p. 154), a ideia partiu dos ruístas baianos. Supostamente, a comemoração referia-se aos cinquenta anos da estreia de Rui na vida pública, com um discurso em homenagem a José Bonifácio, em 1868. Porém, a escolha desse marco inicial era bastante arbitrária, pois Rui já havia feito outros discursos antes. Isso corrobora a hipótese, aventada por Gonçalves, de que a motivação inicial dessas comemorações tenha sido política e baiana. Os oposicionistas desejavam aproveitar o grande prestígio de Rui para impulsionar a luta contra o poder seabrista enraizado no estado.

Os rituais do Jubileu foram grandiosos, tanto em Salvador como no Rio de Janeiro. Na Bahia, louvava-se a baianidade do homenageado, em festas, passeatas, banquetes, conferências. Uma publicação chamada Álbum da Bahia foi produzida em homenagem a Rui, e seus aliados fizeram uma caixa protetora com a madeira da porta da casa onde ele nasceu no centro de Salvador. Essa caixa, que pesa seis quilos e tem uma águia entalhada, está no museu da casa de Rui, no Rio de Janeiro, ainda hoje. O próprio governador Antônio Muniz participou dessas festividades, pois elas envolviam o Rui intelectual, orgulho do Brasil e glória da Babia, em torno do qual toda a vida política e cultural do estado, naqueles dias, parecia gravitar (Figura 17).

A comemoração do Jubileu foi uma preparação simbólica para as lutas que ainda estavam por vir. A partir de 1919, o confronto entre Rui e Seabra voltaria a ganhar um caráter concreto, como em 1912, com os "próceres” terçando armas em um duelo pela supremacia na Bahia. 
Figura 17. Jubileu de Rui Barbosa na Bahia (1918)

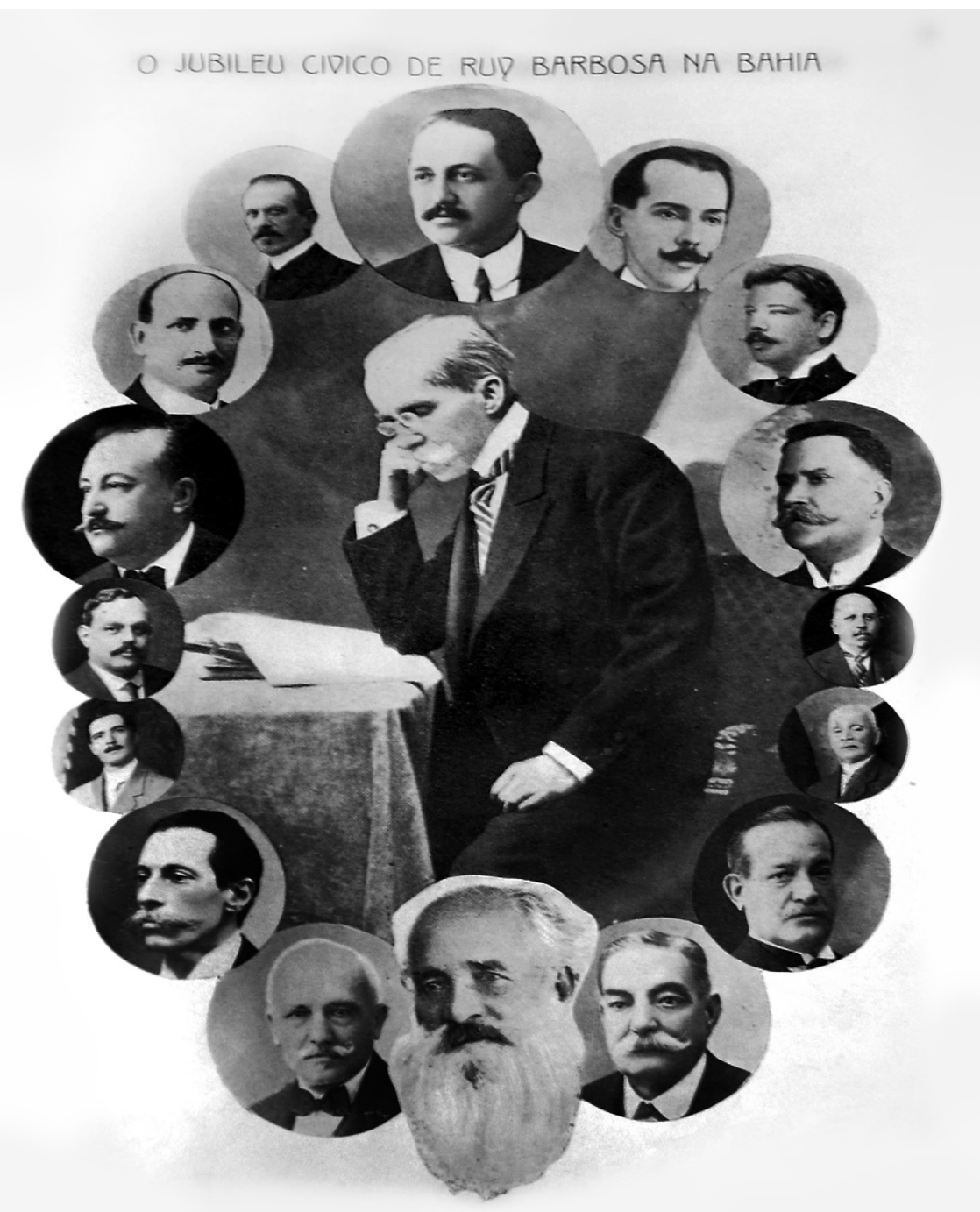

Fonte: Revista Bahia Ilustrada, 1918. Acervo da Biblioteca Pública do Estado da Bahia.

O homem no alto da foto, acima da cabeça de Rui Barbosa, é o governador Antônio Muniz. Em sentido horário, a partir dele, seguem: Lemos Brito, Henrique Câncio, Batista Marques (jornalistas), Costa Lino (presidente da Associação Comercial da Bahia), Carneiro da Rocha (diretor da Faculdade de Direito), Américo Oliveira, A. Motta (industrial), Carneiro Ribeiro (professor e "grande mestre de Rui", conforme a legenda original), Pedro Valente (industrial), Xavier Marques (jornalista), Bernardino de Sousa (secretário do Instituto Histórico), Francisco Góes Calmon (advogado), Álvaro Cova (chefe de polícia), Costa Pinto (diretor da Imprensa Oficial) e Bráulio Xavier (presidente do Superior Tribunal). 


\section{Greve na capital, conflito no sertão (1919-1920)}

Os últimos anos do governo Antônio Muniz foram movimentados. A Primeira Guerra Mundial agravara os problemas financeiros do Estado. A população sofria com o aumento do custo de vida, especialmente com os altos preços dos alimentos. Diversas categorias profissionais foram prejudicadas com a guerra, que aumentou o desemprego, fomentando a insatisfação popular. Havia, além disso, uma onda mundial de mobilização dos trabalhadores, após as duas revoluções na Rússia em 1917, e suas repercussões. Algumas cidades brasileiras, como São Paulo, vinham sendo sacudidas por greves e outros movimentos populares. A capital da Bahia não ficaria alheia a essa atmosfera de agitação.

Em janeiro de 1918, os professores municipais recusaram-se a iniciar o ano letivo, em protesto pelo atraso dos salários. Contaram com o apoio da oposição, que, cada vez mais, identificava-se como ruísta. Em maio, o governo estadual foi acusado de empastelar o jornal $A$ Hora, de Artur Ferreira, um ex-seabrista que passou à oposição. O Diário da Bahia, também anti-Seabra, se ofereceu para imprimir $A$ Hora em suas oficinas, mas a polícia interveio e, em meio à confusão, um estafeta dos telégrafos foi morto a tiros. $\mathrm{O}$ chofer de Simões Filho levou quatro facadas de Inocêncio Sete Mortes, conhecido valentão, capoeira e guarda civil..$^{10} \mathrm{O}$ governo resolveu proibir os meetings, a não ser quando autorizados pela polícia.

No Senado, Rui Barbosa, que havia pedido licença de saúde, compareceu à sessão especialmente para solicitar providências contra o "regime de terror" vigente na Bahia. Foi interrompido por apartes de Seabra que agora também era senador (foi eleito para a vaga aberta com a morte

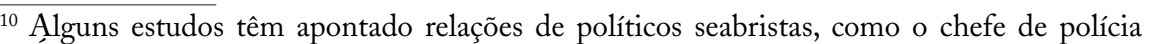
Álvaro Cova e o próprio Seabra com capoeiristas de Salvador. Essa relação aparece, por exemplo, na dissertação de Josivaldo Pires de Oliveira (2004). É interessante notar que, apesar disso, o período seabrista foi também de tentativa de disciplina sobre grupos sociais marginalizados, com a criação da polícia civil. A presença de Inocêncio Sete Mortes na polícia é um indício de que, apesar do discurso discriminatório contra os capoeiras (inclusive na lei), eles continuavam sendo importantes aliados nos embates dos partidos tradicionais.
} 
de José Marcelino). Seabra disse que Rui estava "iludido" por informações equivocadas e defendeu a ação da polícia. (DCN, 30/05/1918) Dois meses depois, Artur Ferreira voltou ao noticiário por ter matado o tenente e deputado estadual Propício da Fontoura, quando este o confrontou sobre artigos ofensivos à sua honra. Em março de 1919, a tensão se elevou ainda mais. Um meeting da oposição na praça municipal foi dispersado a tiros. Simões Filho e Medeiros Neto ficaram feridos. Miguel Calmon e Pedro Lago escaparam correndo. Note-se que o acirramento dos ânimos levava até os "próceres" mais aristocráticos, como Miguel Calmon, neto do marquês de Abrantes, às ruas, para os meetings. Mais uma vez, os piores danos foram sofridos por um homem do povo, que foi baleado e morreu.

A oposição baiana se articulava, em 1919, em torno da nova campanha presidencial de Rui Barbosa. Dessa vez, tratava-se de uma eleição extemporânea, para substituir o presidente eleito Rodrigues Alves, que morreu antes da posse. Como sempre, Rui foi logo cotado como candidato natural ao cargo. Quando a "convenção nacional" se reuniu, no entanto, um acordo entre sete chefes estaduais (inclusive Seabra) definiu que o escolhido seria o paraibano Epitácio Pessoa. Rui não se conformou com a decisão. Dez anos depois da campanha civilista, teve ânimo para uma nova empreitada eleitoral, com chances de sucesso ainda mais remotas, pois os únicos governos estaduais que o apoiavam eram os do Rio de Janeiro (Nilo Peçanha) e Pará.

A Bahia seabrista lhe recusou apoio. Segundo Rui, o "grito de Caim" se fez ouvir na convenção, para repudiá-lo "em nome da Bahia, mãe idolatrada”, estremecida de aversão "à prole bastarda que se manchou no sangue materno, capturando-a como presa inimiga, assaltada e bombardeada". (BARBOSA, 1919, v. 46, t. 1, p. 35) Os termos Caim e bombardeio voltavam, como se vê, a ocupar lugar de destaque no vocabulário político de Rui.

$\mathrm{Na}$ campanha eleitoral que se seguiu, ele proclamou cinco conferências públicas: duas no Rio de Janeiro, uma em São Paulo, uma em Minas Gerais, e a última na Bahia. A conferência baiana, realizada no 
Politeama (12 abr. 1919), foi quase integralmente dedicada à critica do seabrismo. Usando um artifício de retórica, em que comparava a caixa do tesouro estadual a um recipiente hidráulico, Rui declarou que o problema da Bahia era que os recursos escorriam pelos furos, pelos escoadouros, pelos "ladrões". (BARBOSA, 1919, v. 46, t. 2, p. 47) Sua visita a Salvador, em meio a um período de conturbação política, serviu para galvanizar ainda mais a oposição. Otávio Mangabeira lançou o novo lema: Rui ou a revolução. Era uma palavra de ordem inteligente, pois funcionava em dois sentidos opostos: energizava as multidões nas ruas, empolgadas com a onda revolucionária, mas também amedrontava as "classes conservadoras", sempre temerosas de subversões da ordem. Entre Rui e a revolução, elas certamente preferiam Rui.

A presença de Rui mexeu também com os seabristas. O Democrata, jornal que substituiu a Gazeta do Povo como órgão do seabrismo em 1916, publicou uma série de artigos chamando Rui de Anticristo, com sua "imaginação infernal" e "suprema vaidade". O próprio Seabra respondeu à conferência de Rui com uma sarcástica Carta Aberta, reproduzida com comentários no apêndice, em que insinuava até que o adversário sofria de decadência mental. Estava aberta uma nova temporada de hostilidades, acusações e insultos entre os dois baianos.

Apesar da importância da visita a Salvador para a oposição baiana, o ponto alto dessa campanha presidencial de Rui foram os discursos proferidos no Rio de Janeiro. O primeiro deles, intitulado Às Classes Conservadoras, era um apelo para que essas "classes", que eram as "células vivas" da sociedade, retomassem a política das mãos dos "parasitas" da politicalha. Mas, quem eram as "classes conservadoras", na opinião de Rui? Sua definição abrangia, não só a lavoura, a indústria e o comércio (as "classes conservadoras" na concepção mais difundida na época), mas também o funcionalismo público, os militares e os operários, todos que produzissem algo benéfico em prol da sociedade. Era uma definição muito elástica, que parece ter servido mais como ele- 
mento retórico do que como conceito real. Ficavam excluídos das "classes conservadoras" apenas os maus políticos, apontados como os causadores de todos os males do Brasil.

O segundo discurso, A Questão Social e Politica no Brasil, foi voltado aos operários. Nele, Rui se ocupou, pela primeira vez, da "questão social", demonstrando uma importante mudança em seu pensamento político, que se afastara do liberalismo individualista clássico para admitir "medidas tutelares" em relação ao operário, nos moldes de uma "democracia cristã”. Seu exemplo ideal de relação patrão-empregado eram as vilas operárias criadas em São Paulo pelo industrial Jorge Street. A principal preocupação expressa por Rui, nos dois discursos, era de que o acirramento das tensões sociais, agravado pela intransigência dos sucessivos governos, levasse o regime brasileiro a um desfecho semelhante ao do kayserismo alemão ou do czarismo russo: "a guerra ou, pior, a anarquia", no sentido lato de dissolução da ordem.

Assim é que, senhores, já não é a anarquia uma palavra, um mal vago remoto, exótico, dominável pela força organizada. É uma alucinação reduzida à prática. É um pesadelo introduzido na vida real. É uma contingência iminente, um inimigo à porta e poderia vir a ser, de um momento para outro, uma realidade atual. Tóxico sutil nas combinações debaixo das quais se propina à consciência dos humildes, sente-se menos nas alturas, porque, nas suas tendências gerais, participa da natureza de certos gases pesados, como o óxido carbônico, que gravitam para as camadas baixas do ambiente, e rastejam com a morte pelo chão. Mas por toda parte se infiltra, em toda parte se acha, e de toda parte ameaça. (BARBOSA, 1919, v. 46, t. 1, p. 59)

Rui não era o único a se preocupar com esse "tóxico sutil", que se espalhava preferencialmente "nas camadas baixas do ambiente". Desde o começo da República, esses temores rondavam as mentes dos "próceres", preocupados com a estabilidade social. Progressivamente, a questão foi ganhando visibilidade, na medida em que greves e outros movimentos 
passaram a fazer parte da vida das grandes cidades brasileiras. Em 1910, na plataforma hermista, já apareciam referências ao problema operário. Apesar de minimizar a questão ("Não nos assoberbam ainda, felizmente, os grandes abalos produzidos pela luta entre o braço e o capital") e de achar que o socialismo, no Brasil, seria "planta exótica" incapaz de brotar, Hermes estava atento a essa força social. Em 1912, ele organizou um congresso de trabalhadores, uma forma de tentar manter um controle sobre suas reivindicações. (GAZETA DO POVO, 03 jan. 1910) Nos anos posteriores, com a evidência de que o terreno ideológico se mostrava cada vez mais fértil à rebeldia, as autoridades passaram a se preocupar ainda mais.

Um exemplo baiano: em 1918, o governador Antônio Muniz afirmou que, apesar dos problemas financeiros do estado, não paralisaria as obras públicas de Salvador para não desempregar os trabalhadores, que "se veriam, de chofre, desamparados e sem pão, sob as tristes ameaças da miséria”. Não era apenas uma medida de compaixão, explicou, mas uma questão política, pois "em momentos de crises sociais como esta que atravessa o mundo, daria provas de chocante desumanidade e de imprudência política, o governo que, em vez de suavizar a dura existência do proletariado, fosse agravar as suas dificuldades, retirando os meios de vida àqueles que se entregam ao trabalho". (BAHIA, 1918, p. 6, grifo nosso) $\mathrm{O}$ discurso foi apresentado por Antônio Muniz à Assembleia Legislativa poucos meses depois da Revolução Russa de 1917, que mudou para sempre a forma como as "classes conservadoras" olhavam para as "classes laboriosas", nos alicerces do "edifício social".

Em junho de 1919, os operários baianos fizeram sacudir o edifício, com a primeira greve geral de Salvador. O movimento se iniciou no sindicato dos pedreiros, estendendo-se, aos poucos, para outros ramos profissionais. Em poucos dias, a maior parte das fábricas e oficinas estava fechada. Trabalhadores dos serviços públicos também aderiram, e a cidade ficou sem energia e sem transportes. Além da abrangência, o movimento também ficou marcado por ter adotado uma postura di-

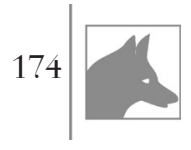


ferente dos protestos contra a carestia, tão conhecidos da população baiana. Liderada pelo advogado Agripino Nazaré, a greve assumiu reivindicações relacionadas mais de perto ao mundo do trabalho, como a diminuição da jornada de trabalho, regulação da mão-de-obra infantil e feminina, entre outras. (CASTELLUCCI, 2001)

$\mathrm{O}$ fato de a greve ter ocorrido em um momento de grande tensão política entre seabristas e ruístas fez com que os dois grupos estivessem dispostos a firmar uma aliança com os operários, que puderam escolher o lado que lhes proporcionaria maiores benefícios. Optaram pelo governo do Estado que, além disso, já tinha uma relação antiga e consolidada com setores do operariado baiano. Apesar das resistências de Agripino Nazaré, que queria manter o movimento grevista independente dos políticos externos, era inegável que alguns sindicatos, como o dos estivadores, tinham uma relação próxima com políticos seabristas. No caso da greve geral, quem serviu de intermediário junto aos patrões foi o próprio governador Antônio Muniz, que defendeu as demandas dos grevistas e não reprimiu o movimento ${ }^{11}$.

A postura do governo estadual, favorável aos operários, desagradou, por sua vez, à Associação Comercial da Bahia, porta-voz das "classes conservadoras". A entidade já vinha entrando em conflito com o governador desde que Antônio Muniz, diante da pressão social, tomou medidas de intervenção na economia para minorar a carestia dos alimentos, como a fixação de uma tabela de preços. A atuação na greve geral foi a gota d'água para as "classes conservadoras", que passaram a se aliar à oposição ruísta. Os jornais oposicionistas falavam em soviete dos Munizes. Não deixa de ser irônico que a expressão designasse a parentela do

\footnotetext{
${ }^{11}$ Antônio Muniz não reprimiu o movimento de 1919 por conta das necessidades políticas do momento, mas, como observa Castelucci (2001), a aliança entre o seabrismo e os líderes da greve se encerrou no segundo mandato de Seabra, quando Agripino Nazaré foi expulso da Bahia. A prática de expulsar anarquistas e subversivos em geral não era incomum no período. Além daqueles que representavam perigo para a ordem social, era frequente também a expulsão de pessoas que pareciam ameaçar a ordem moral, como as prostitutas. Por isso mesmo, a polícia do porto de Salvador costumava fazer uma "triagem" para definir quem podia ou não desembarcar.
} 
governador Antônio Muniz e de seu primo Muniz Sodré, tão zelosos do seu "sangue azul" que, anos antes, foram chamados de "fidalgotes" por um adversário, como já se registrou.

Articuladas à oposição, as próprias “classes conservadoras” lançaram um candidato ao governo da Bahia, o juiz federal Paulo Martins Fontes. $\mathrm{O}$ candidato governista era o próprio Seabra, que voltava para tentar retomar o controle do partido, bastante fragilizado após a gestão Muniz. Além dos problemas externos, o seabrismo sofria uma profunda crise interna. Antônio Muniz não conseguiu manejar as complexidades da política baiana, deixando que o poder concentrado pelo chefe se desagregasse. Amargou perdas como a do deputado federal Otávio Mangabeira, que se uniu a outro ex-seabrista, Ernesto Simões Filho, para comandar as oposições baianas sob as ordens do chefe máximo de ambos: o senador Rui Barbosa. (BARBosA, 1919, v. 46, t. 3, p. 8)

De fato, apesar de o candidato oposicionista ser Paulo Fontes, a campanha eleitoral foi um duelo Rui X Seabra. Rui se engajou nessa campanha como se sua própria vida dependesse disso. Aos 71 anos, com a saúde precária de sempre, saiu pelo interior da Bahia em longos percursos de trem, de navio e até de canoa. Palestrou em Alagoinhas, Serrinha, Santo Amaro, Cachoeira, Bonfim e Feira de Santana, além de Salvador, no período de 35 dias. Com todo esse esforço, e sua popularidade, a campanha baiana ganhou visibilidade nacional. Da Europa, por cartas, seu filho mais novo, João Rui, acompanhava as "estripulias" do pai "pelos sertões da Mulata Velha", como era chamada a Bahia. "Até parece que tem bicho-carpinteiro a fazer-lhe cócegas!", comentou João Rui com seu correspondente e informante, o mordomo Antônio, que acompanhava todos os passos do patrão. (BARBOSA, 1919 v. 46, t. 3; FCRB/ARB/CRUPF 147 16/01/1920)

Nessas conferências públicas, Rui voltou a destilar o melhor da sua retórica para dizer o pior do adversário. Eram textos violentos, cheios de acusações retumbantes e pertardos irônicos contra a oligarquia "dos 
Antoninhos e dos Jotas". Muitas vezes, ele recorreu a imagens chocantes de doença e podridão, de lepra e pus, para caracterizar a corrupção e a violência governamental. Comparou os adversários a vermes, quando falou em extirpar a "tênia do seabrismo, metida, há oito anos, nos intestinos da Bahia". Ridicularizou a aparência de Seabra, com suas "carnudas proeminências faciais", seu "carão", "tez sensível ao pó de arroz", e também seu estilo retórico, a forma peculiar da argumentação seabrista, que, após estabelecer as premissas, costumava enfatizar a conclusão supostamente irrefutável com um logo sonoro e prolongado. Para Rui, Seabra era o Senador Lóóógo, o Demóstenes de Trovoada, o Frei Tartufo, de "miolo mole e cara dura". (BARBOSA, 1919 v. 46, t. 3, p. 91, 125, 134, 80)

A escolha de Paulo Fontes foi formalizada em uma Convenção do Povo Baiano (20 nov. 1919), no Politeama, Assembleia supostamente representativa de "todas as classes" da sociedade. Em seu primeiro discurso solene, realizado nessa mesma noite, Rui já introduziu os principais temas que orientariam suas conferências ao longo da campanha eleitoral. Ele disse que essa não era uma campanha movida pelo interesse partidário, mas uma cruzada de libertação da Bahia do jugo da oligarquia. A "salvação do Estado" dependeria da ação das suas forças vivas, da "intervenção direta da vontade popular", especialmente dos homens do esquecido sertão, essa "raça heróica e honesta" que estaria se preparando para intervir na política estadual, resgatando a dignidade vilipendiada de sua terra. $\mathrm{O}$ uso dos termos oligarquia, salvação e intervenção não parece ter sido gratuito, pois se relacionava à estratégia desenhada desde aquele primeiro momento por Rui e seus aliados.

A situação de 1919 era exatamente o inverso daquela de 1912. Dessa vez, eram os ruístas que precisavam quebrar as cadeias do continuismo vigentes no estado. Diante da impossibilidade de cooptar o futuro governador, pois, afinal, o candidato governista era próprio Seabra, a oposição precisava recorrer à força do governo federal. Mas o artigo $6^{\circ} \mathrm{da}$ Constituição de 1891 proibia a intervenção federal nos estados, exceto para: 
- repelir invasões estrangeiras e entre os estados;

- manter a forma republicana federativa;

- reestabelecer a ordem e a tranqüilidade nos estados à requisição dos respectivos governos

- assegurar a execução das leis e sentenças federais.

As duas últimas exceções (manter ordem e cumprir leis/sentenças) vinham sendo usadas, desde o início da República, para justificar a intervenção nos estados, a favor de aliados do governo federal. Para acionar esse recurso, as oposições estaduais precisavam: a) contar com o apoio do governo federal, b) criar uma situação de conflito em que se pudesse justificar a intervenção, enquadrada em uma das exceções citadas.

Rui vinha buscando, claramente, conquistar o apoio do presidente Epitácio Pessoa. Sua primeira ação nesse sentido ocorreu imediatamente após as eleições, quando ele reconheceu a vitória do adversário e não contestou os votos por ele obtidos. Era uma postura bem diferente da que Rui assumiu em 1910, quando escreveu um longo memorial contestando a eleição de Hermes. Além de reconhecer a vitória de Epitácio, Rui salientou que sempre o respeitou durante a campanha. Ele sabia que o novo presidente não tinha um bom relacionamento com Seabra e queria garantir o apoio para seu grupo na Bahia. A estratégia parecia promissora. Diversos funcionários federais seabristas começaram a ser demitidos, o que sinalizava o apoio de Epitácio à oposição. Mais importante: houve uma mudança no comando da guarnição militar instalada na Bahia, com a substituição de um general simpático a Seabra por um militar ligado aos ruístas. Tudo isso dava novas esperanças aos partidários de Rui.

Para viabilizar a intervenção, a oposição também precisava de uma sentença favorável ao grupo, o que era bem simples, pois o candidato de Rui era o próprio juiz federal. Os ruístas contavam, também, com outros importantes magistrados baianos, como Bráulio Xavier, outro ex-seabrista de 1912. Mas, havia ainda outra questão. Normalmente, as 
intervenções federais ocorriam em momentos de agitação, em que se justificava a ação externa em nome da salvação pública. Era nesse ponto que entravam os sertanejos tão elogiados por Rui. Em suas conferências pelo interior do estado, ele clamou pelos brios dos homens do sertão:

Seria possível que qualquer coisa capaz de usar o nome de povo, seria possível que o mais baixo povo do mundo, quanto mais o povo brasileiro, quanto mais o povo baiano, se acomodasse a chafurdar nesse atascadeiro vilíssimo sem uma reação eficaz, sem uma reação heróica, sem uma reação de todos os seus instintos, de toda sua consciência, de toda sua energia? Seria possível que as virtudes sertanejas, no momento em essa política abdominosa e voraz, obra do coito da hiena com o varrasco, a política do bombardeio de Salvador e da bancarrota da Bahia, no momento em que essa política espúria e degenerada vai jogar todos os trunfos na última cartada pela sua eternidade no Governo do Estado que desonrou - seria possível que a moralidade, o civismo e o pundonor desta raça de heróis do trabalho, da modéstia e do sofrimento [...] escolhesse o cogote e desfilasse de corrida para casa como a ovelhada a caminho do aprisco, ao latir dos cães do ovelheiro? (BARBOSA, 1919, v. 46, t. 3, p. 44-45)

Os sertanejos não eram ovelhas, como Seabra sabia muito bem. Como já se comentou, ele havia tentador exercer seu mando no interior da Bahia, onde tinha antigas dificuldades de aceitação. A reforma da Constituição Estadual e a lei de nomeação de intendentes foram estratégias para concentrar o poder nas mãos do governador. Essa iniciativa, no entanto, acabou despertando a ira de muitos chefes, que não aceitavam ter que depender do beneplácito do governo para exercer o poder em seus próprios municípios. Além disso, a interferência da polícia estadual a favor dos chefes governistas na gestão de Antônio Muniz (abandonando a estratégia de Seabra de esperar a briga e se aliar com o vencedor, que era o mais forte), provocou a reação de vários “coronéis", incomodados com a interferência nas lutas locais. Os partidários de Rui perceberam essa inquietação e convocaram esses "coronéis" para a campanha "libertadora" 
da Bahia. Estava formada, assim, a base do que a historiografia costuma chamar de Reação Sertaneja, Revolução Sertaneja ou Levante Sertanejo. ${ }^{12}$

Os principais chefes guerreiros envolvidos no movimento eram o coronel Horácio de Matos, das Lavras Diamantinas, coronel Anfilófio Castelo Branco, do São Francisco, e coronel Marcionílio de Sousa, de Maracás. Enquanto o governo estadual e a oposição engalfinhavam-se em torno dos números da eleição, com os processos rotineiros de violência e fraude, os "coronéis" lutavam no interior contra as forças policiais. Os conflitos eram narrados, de forma dramática e exacerbada, no jornal A Tarde, de Simões Filho, que alardeava que, a qualquer momento, os guerreiros do sertão marchariam sobre a capital. Tudo isso contribuía para disseminar o pânico na população. Antônio Muniz não teve saída a não ser solicitar a intervenção para "reestabelecer a ordem e a tranquilidade" (23 fev. 1920). Porém, ao contrário do que esperava a oposição, Epitácio Pessoa deixou os seabristas no poder, embora tenha tentado convencer Seabra a renunciar. Para pacificar o sertão, os emissários do presidente negociaram diretamente com os "coronéis", que só baixaram as armas depois de assinar tratados proveitosos, que lhes garantiam o domínio de amplas regiões da Bahia.

Rui ficou, evidentemente, enfurecido com o desfecho da luta pela qual tanto se esforçou. Travou uma polêmica com Epitácio Pessoa nos jornais sobre a questão da intervenção na Bahia. Para Rui, o governo baiano era o responsável pelas desordens, portanto o presidente não poderia, a pretexto de estabelecer a ordem, "manter a desordem". Apesar dos argumentos, sempre cheios de erudição e expressividade, era evidente que Rui defendia a intervenção porque era a favor do seu grupo. Toda a sua argumentação era baseada na premissa da ilegitimidade do poder do governo estadual e na legitimidade das ações dos seus aliados. No fundo, era a mesma situação da época do bombardeio, com sinais trocados. O que Epitácio Pessoa fez, em 1919, foi o que Rui exigiu de

$\overline{12}$ Sobre o Levante Sertanejo, ver MORAES (1997), NOVAES (2009), PANG (1979) e SAMPAIO (1998). 
Hermes em 1912: a manutenção do poder já estabelecido no estado. (BARBOSA, 1920 v. 47, t. 3, p. 30)

Seabra tomou posse do governo da Bahia pela segunda vez (29 mar. 1920), mas tinha um alto preço a pagar. Indisposto com o presidente Epitácio, desmoralizado diante dos "coronéis", não conseguiria retomar o controle sobre a política baiana. Ele ainda revogou a lei que extinguiu a eleição dos intendentes, mudou assessores do governo e convocou um pioneiro congresso de intendentes municipais, em 1921, para tentar reverter a crise. Nada disso evitou seu progressivo declínio. Mas, antes do fim, Seabra ainda teria a chance de uma última e breve reaproximação do seu antigo amigo e maior adversário.

\section{Morte de Rui e declínio de Seabra (1921-1923)}

Parecia impossível que, após as agressões mútuas de 1919, Rui e Seabra se reconciliassem, mas isso aconteceu. Passada a fase crítica, os dois baianos voltaram a ter relações amistosas. Em 22 de maio de 1921, Rui renunciou ao seu mandato no Senado, desiludido com os rumos da política brasileira. $\mathrm{O}$ ato causou, claro, comoção imediata no país. Como governador da Bahia e chefe do partido dominante, Seabra determinou imediatamente aos seus subordinados que Rui fosse reconduzido ao Senado, como candidato único, nas eleições realizadas no mês seguinte. Era uma atitude muito típica de Seabra, que buscava reverenciar e agradar Rui em todas as ocasiões, a não ser que isso significasse abrir mão do próprio mando. De qualquer forma, dessa vez, não era o caso. A deferência agradou o velho senador.

No mesmo ano, Seabra foi candidato à vice-presidência da República, na chapa oposicionista liderada por Nilo Peçanha. Era o movimento conhecido como a Reação Republicana, que veio a ser a primeira eleição presidencial após a campanha civilista a envolver de forma significativa a população urbana. Para Seabra, foi uma oportunidade única de, a um 
só tempo, escapar às pressões e dificuldades do seu segundo mandato na Bahia, e arriscar a sorte de alcançar um dos cargos mais disputados do primeiro escalão da política nacional.

Desde Manuel Vitorino, nenhum baiano atingira a vice-presidência. A oposição ao seabrismo na Bahia ficou indecisa sobre a atitude a tomar nessas eleições. Pediram a opinião de Rui Barbosa, que disse que nada tinha a opor à candidatura de Seabra. Em carta a Simões Filho, respondeu: "considerando-me retirado da política, não vi no candidato baiano à vice-presidência senão a Bahia, depreciada sempre nessas ocasiões [...] Da revolução abandonada, só se salvou a imagem eterna da Bahia. A ela, este meu derradeiro sacrifício". (FCRB/ARB/CRUPF 1388 1921) Apesar do grande esforço despendido por Seabra e Nilo Peçanha na campanha, que contou com excursões pelo país, a chapa oposicionista foi derrotada.

O novo presidente, o mineiro Artur Bernardes, não era nem um pouco simpático à continuação do mando seabrista na Bahia e estimulou o fortalecimento da oposição no estado. A pressão sobre Seabra era cada vez mais forte, especialmente no tocante à sucessão. Em fevereiro de 1923, ele ainda tentou ter o apoio de Rui, em uma tentativa desesperada de segurar o poder que lhe escapava das mãos. Seu ajudante, nessa missão, foi Joaquim Pereira Teixeira, o mesmo que já servira de intermediário entre os dois quando da sucessão de 1915.

Em carta a Rui, Pereira Teixeira disse que o candidato sugerido por Seabra para o governo do Estado, Arlindo Leoni, dedicava a ele, Rui, uma "reverente admiração". Após uma reunião com seus aliados políticos, Rui rejeitou a proposta de conciliação, a não ser que o governador atendesse às seguintes condições: renúncia do governo; cessão de metade das vagas da Câmara Estadual para a oposição; escolha de um nome oposicionista ou neutro para a sucessão. Isso significava propor a Seabra o suicídio político, que ele não aceitou. (SAMPAIO, 1998)

Até os últimos dias de vida, Rui Barbosa esteve plenamente engajado nas questões da Bahia. Conforme o registro de João Mangabeira 
(1999), foi durante uma reunião com políticos baianos que Rui teve sua crise final de saúde, indignado com uma carta de Aurelino Leal que defendia que a escolha do futuro governador (ou seja, do governador que substituiria Seabra, após seu declínio) deveria ser feita pelo presidente da República. Para Rui, isso era inaceitável. De acordo com João Mangabeira, que estava na reunião, a emoção com que o senador defendeu sua posição foi demasiada para sua saúde frágil.

Quatro dias depois (1º mar 1923), Rui Barbosa faleceu. Não chegou a ver a queda de Seabra, mas sabia que seu domínio estava com os dias contados. A morte de Rui tornou-se mais um símbolo para motivar a derrubada da "oligarquia" seabrista que, a cada momento, ficava mais diminuta e isolada. Quando Seabra foi finalmente deposto, em 1924, durante mais uma intervenção do governo federal, estava praticamente abandonado. Somente pouquíssimos aliados, entre eles Cosme de Farias, permaneceram ao seu lado na derrocada.

Seabra viveu mais 18 anos depois disso, falecendo em 1942, aos 87 anos de idade. Permaneceu ativo na política, embora sem a mesma preponderância do período 1912-1924. Participou da Assembleia Nacional Constituinte de 1934, sendo um dos dois únicos parlamentares brasileiros que participaram das duas primeiras Constituintes republicanas. Teve tempo ainda de se reconciliar com Otávio Mangabeira e Simões Filho, que voltaram a ser seus aliados no combate ao governo de Juraci Magalhães. Reconciliou-se também com a memória de Rui. Dois meses antes de falecer, em entrevista à revista Diretrizes (1942), Seabra declarou que ele e Rui eram inimigos políticos, mas que jamais deixaram de ser amigos pessoais.

A análise de suas trajetórias políticas, que se buscou neste trabalho, revela mais semelhanças do que divergências. Além da origem social e da formação semelhantes, Rui e Seabra usaram, em geral, os mesmos métodos políticos, que eram os disponíveis no Brasil do seu tempo. Se Seabra aproveitou o tumulto do bombardeio, Rui estimulou o conflito no sertão. Ambos recorreram à intervenção federal quando necessário. Não 
havia uma diferença ideológica fundamental em seus discursos. Muitos dos políticos contemporâneos a eles transitaram entre um e outro. Paulo Fontes e Bráulio Xavier, magistrados que respaldaram a ascensão de Seabra em 1912, ficaram do lado de Rui em 1919. Simões Filho e Otávio Mangabeira começaram seabristas, depois viraram ruístas. Júlio Brandão, colocado na intendência por Seabra, depois virou sócio de Rui. O cônego Galrão, outra peça chave do bombardeio, fez o caminho inverso: começou do lado de Rui e depois passou para o de Seabra. O mesmo aconteceu com Bernardo Jambeiro, antes acusado por Seabra de atentar contra sua vida em 1910 (na cidade de Castro Alves), e depois seu aliado.

Por fim, Rui e Seabra compartilhavam outra característica que parece ser a mais importante: ambos conseguiram movimentar o debate político fora dos círculos estritamente partidários, envolvendo a população como um todo. As pessoas se engajavam, inclusive emocionalmente, tomavam partido, lutavam nos combates, de uma forma que seria impensável na relação com os "próceres" aristocráticos do Império, por exemplo. Nesse sentido, Rui e Seabra fizeram a transição entre um modelo político mais francamente elitista, distante da população, para outro em que a multidão passaria a ser parte fundamental.

Nessa transição, eles estabeleceram temas que repercutiram na política baiana posterior. De Seabra, o modelo de homem forte, viril, modernizador, vinculado ao saber técnico (seu braço direito, o engenheiro Arlindo Fragoso, foi o fundador da Escola Politécnica), mas capaz de derramar lágrimas em defesa apaixonada da Bahia-mãe. De Rui, o modelo do jurista, da retórica sofisticada, da argumentação liberal. Esses dois modelos convergiram, por exemplo, na figura de Otávio Mangabeira, que governou a Bahia na década de 1950. Aspectos desses modelos, ou da negação deles (o que também atesta sua permanência) podem ser encontrados na atuação de políticos como Juraci Magalhães e Antônio Carlos Magalhães. Mas, a discussão aprofundada dessas questões já mereceria um novo trabalho. 
Figura 18. Caricatura dupla

Os extremos setocam...

\section{de pernas para o ar.}

RUY

Um nome bem collocado

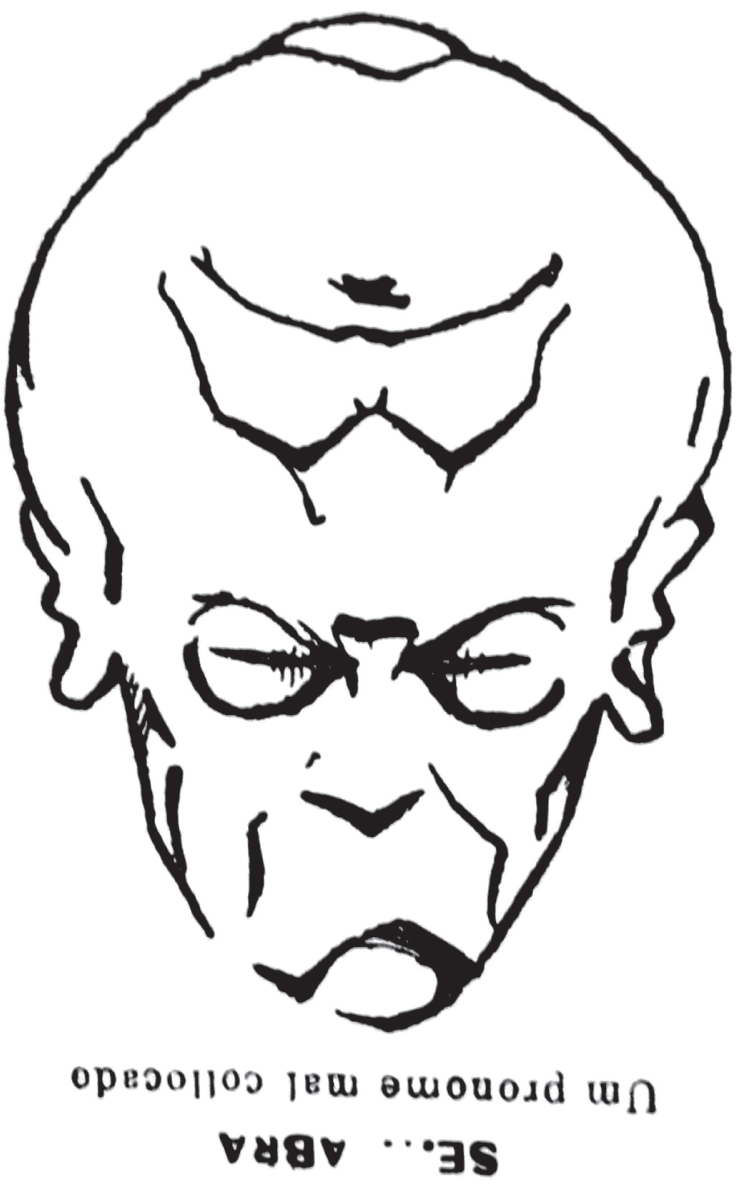

Theo 